Denise Gonçalves Moura Pinheiro

\title{
Práticas de promoção da saúde no atendimento fisioterapêutico em uma instituição hospitalar de referência em Cardiologia
}

\author{
Dissertação apresentada à Faculdade de Medicina \\ da Universidade de São Paulo para obtenção do \\ título de Mestre em Ciências \\ Área de concentração: Medicina Preventiva \\ Orientador: Prof. Dr. Heráclito Barbosa de Carvalho
}

São Paulo 
Denise Gonçalves Moura Pinheiro

\title{
Práticas de promoção da saúde no atendimento fisioterapêutico em uma instituição hospitalar de referência em Cardiologia
}

\author{
Dissertação apresentada à Faculdade de Medicina \\ da Universidade de São Paulo para obtenção do \\ título de Mestre em Ciências \\ Área de concentração: Medicina Preventiva \\ Orientador: Prof. Dr. Heráclito Barbosa de Carvalho
}

São Paulo

2009 
Dados Internacionais de Catalogação na Publicação (CIP)

Preparada pela Biblioteca da

Faculdade de Medicina da Universidade de São Paulo

Creprodução autorizada pelo autor

Pinheiro, Denise Gonçalves Moura

Práticas de promoção da saúde no atendimento fisioterapêutico em uma instituição hospitalar de referência em Cardiologia / Denise Gonçalves Moura Pinheiro. -- São Paulo, 2009.

Dissertação(mestrado)--Faculdade de Medicina da Universidade de São Paulo. Departamento de Medicina Preventiva.

Área de concentração: Medicina Preventiva.

Orientador: Heráclito Barbosa de Carvalho.

Descritores: 1.Promoção da saúde 2.Educação em saúde 3.Pesquisa qualitativa 4.Fisioterapia (Especialidade) 5.Cardiologia

USP/FM/SBD-353/09 
À minha avó materna (in memorian), exemplo de amor e dedicação, eternas saudades

Ao meu marido, Carlos, pela caminhada, sempre de mãos dadas, em busca de nossos sonhos 


\section{AGRADECIMENTOS}

A Deus, pela vida, pela família que me deu, e por estar sempre iluminando meu caminho

Aos meus pais, pelo amor incondicional, apoio e por me ensinar valores como honestidade, determinação e dedicação aos estudos

Ao meu marido, Carlos Hermano, pelo amor, amizade e por ser meu maior exemplo de dedicação à ciência e à pesquisa

Aos meus sogros, especialmente ao meu querido sogro José Haroldo (in memorian), pelo apoio e palavras de incentivo e carinho

Ao meu orientador, Professor Heráclito Barbosa de Carvalho, pela orientação da pesquisa

Aos professores da banca de qualificação, Professora Amélia Pasqual Marques, Professora Maria Cecília Focesi Pelicioni e Professor José Ricardo de Carvalho Mesquita Ayres, pelas valiosas contribuições à pesquisa

À fisioterapeuta Dra Iracema loco Kikuchi Umeda e à sua equipe, por ter me recebido de braços abertos no departamento de Fisioterapia no qual foi realizada a pesquisa

Aos funcionários do Departamento de Medicina Preventiva da FMUSP

A CAPES, pelo apoio financeiro, essencial à realização desta pesquisa 
"Ninguém pode construir em teu lugar as pontes que precisarás passar para atravessar o rio - ninguém, exceto tu "(Nietzsche) 
Esta dissertação está de acordo com as seguintes normas, em vigor no momento desta publicação:

Referências: adaptado de International Committee of Medical Journals Editors (Vancouver)

Universidade de São Paulo. Faculdade de Medicina. Serviço de Biblioteca e Documentação. Guia de apresentação de dissertações, teses e monografias. Elaborado por Anneliese Carneiro da Cunha, Maria Julia de A. L. Freddi, Maria F. Crestana, Marinalva de Souza Aragão, Suely Campos Cardoso, Valéria Vilhena. 2 ed. São Paulo: Serviço de Biblioteca e Documentação; 2005.

Abreviatura dos títulos dos periódicos de acordo com List of Journals Indexed in index Medicus. 


\section{SUMÁRIO}

\section{Resumo}

Summary

1 INTRODUÇÃO

1.1 Epidemiologia das doenças cardiovasculares

1.2 Fisioterapia Cardiovascular...

1.2.1Reabilitação Cardíaca

1.3.1Educação em saúde e estratégias de intervenção e controle de doenças cardiovasculares.

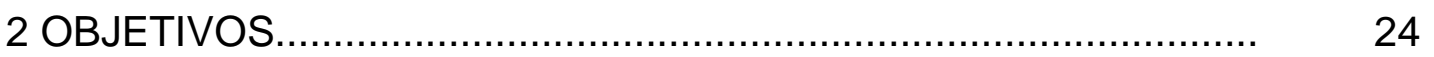

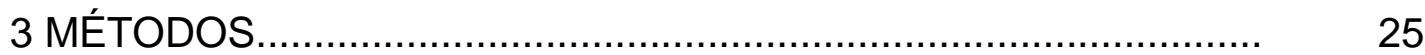

3.1 Caracterização do estudo..................................................... 25

3.2 Local do estudo ..................................................................

3.2.1 A instituição hospitalar........................................................ 26

3.3 Entrada no campo de estudo................................................ 28

3.3.1 Sujeitos da pesquisa......................................................... 29

$3.4 \mathrm{O}$ trabalho de campo............................................................ 30

3.4.1 A observação..................................................................... 31

3.4.2 Entrevistas................................................................ 32

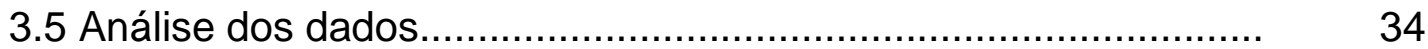

3.6 Aspectos Éticos ....................................................................

4 RESULTADOS E DISCUSSÃO................................................... 36

4.1 As ações de promoção de saúde oferecidas pela instituição........ $\quad 36$

4.2 A visão dos profissionais acerca da promoção da saúde............... 58

4.3 As ações de promoção de saúde e 0 autocuidado dos pacientes: convivendo com uma doença crônica...............................................

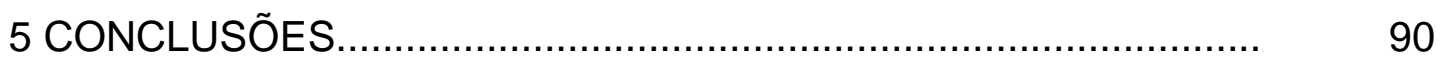

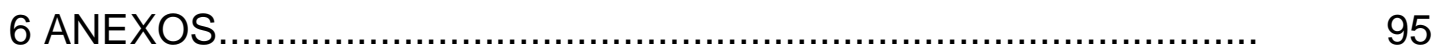

7 REFEREANCIAS.................................................................. 125

Apêndices 


\section{Resumo}

Pinheiro DGM. Práticas de promoção da saúde no atendimento fisioterapêutico em uma instituição hospitalar de referência em Cardiologia. [dissertação]. São Paulo: Faculdade de Medicina; Universidade de São Paulo; 2009. 131p.

As doenças cardiovasculares representam um elevado índice de morbimortalidade no Brasil e no mundo. Desta forma, as ações de promoção da saúde são essenciais para controle e prevenção de doenças crônicas. $O$ potencial do fisioterapeuta como promotor de saúde é grande, porém pouco explorado. O objetivo desta pesquisa foi identificar as ações relacionadas à promoção da saúde realizadas pelo serviço de Fisioterapia em uma instituição de referência em Cardiologia e verificar as percepções de profissionais e pacientes neste contexto. Utilizou-se a pesquisa qualitativa do tipo estudo de caso. Foi realizada a triangulação metodológica, e como coleta de dados, realizou-se observação e entrevistas semi-estruturadas com 8 fisioterapeutas e 7 pacientes da instituição. Após a análise temática, emergiram dois grandes temas das entrevistas: "A visão dos profissionais frente à promoção da saúde" e "As ações de promoção de saúde e o autocuidado dos pacientes: convivendo com uma doença crônica". Foram identificadas sete atividades de promoção de saúde oferecidas aos pacientes da instituição nas quais o papel do fisioterapeuta está bem definido. As atividades tinham cunho preventivista e estavam focadas estritamente na doença. Muitos profissionais tinham dificuldade em definir a promoção da saúde, confundindo com a prevenção, pensando a saúde como "ausência de doença". Segundo a percepção dos profissionais, existia um maior autocuidado por parte dos pacientes, os pacientes eram interessados e procuravam saber a respeito de sua doença, através de meios de comunicação e com perguntas no dia a dia do tratamento. Em relação às dificuldades que os pacientes relatavam a respeito de mudanças em seu estilo de vida ou de adesão ao tratamento, a falta de tempo aparecia como um empecilho à prática de atividade física. Foi observado nas falas de alguns profissionais as alterações físicas dos pacientes decorrentes da patologia cardíaca como fatores limitantes às dificuldades de ida ao hospital. Observamos que após a participação das atividades de promoção de saúde no hospital, os pacientes relataram sim, uma melhora em seu conhecimento de como viver com as novas adaptações que deviam ser incorporadas em seu dia a dia. Destaca-se a participação do fisioterapeuta além de suas atividades reabilitadoras, tornando seu atendimento mais completo, porém os profissionais precisam ampliar seu conceito de saúde, pois pacientes cardíacos precisam de um acompanhamento maior devido à suas múltiplas necessidades.

Descritores: 1. Promoção da saúde 2. Educação em saúde 3. Pesquisa Qualitativa 4. Fisioterapia (Especialidade) 5. Cardiologia 


\section{Summary}

Pinheiro DGM. Health promotion on Physical Therapy care in a reference heart hospital. [dissertation]. São Paulo: Faculty of Medicine; University of São Paulo, SP (Brazil); 2009. 131p.

Cardiovascular disease presents high index of morbi-mortality in Brazil and over the world. Health promotion actions are essential for control and prevention of cardiovascular diseases. The potential of the physical therapists in health promotion is great, however is still little explored. The objective of this research was to identify and describe the actions related to the health promotion on physical therapy practice in a Brazilian heart hospital. The perceptions of professionals and patients in this context were also evaluated. The present study used qualitative methodology in institution case-report. We used methodological triangulation, and as it collects of data, observation and half-structuralized interviews with physiotherapists $(n=8)$ and patients $(n=7)$ of the institution. After the thematic analysis, two thematic axes were emerged: "The vision of the professionals front to the health promotion" and "Health promotion actions and the patient's self-care: coexisting with a chronic illness". Seven health promotion activities had been identified and were offered to the patients of the institution in which the paper of the physical therapists was well established. Activities had a restricted focus on prevention and disease. Several professionals had difficulty in defining the health promotion, confusing with the prevention, thinking the health as "disease absence". According to perception of the professionals, there were a greater self-care by the patients, and they were interested to know about its illness, through communication vehicles and with questions in daily treatment. In relation to the difficulties that patients told regarding changes in lifestyle or adhesion to the treatment, the time lack appeared as one obstacle to the practical of physical activity. It was observed in some professionals interviews that physical alterations of patients were factors that difficulties the visits to the hospital. After we observed that the participation of health promotion activities in the hospital, the patients had noticed an improvement in its knowledge about how to live with the new adaptations that must be incorporated in its daily. It highlights the involvement of the physical therapist in addition to its rehabilitative activities, making its treatment more complete, but professionals must expand their concept of health for heart patients need a closer follow-up due to their multiple needs.

Key-Words: 1. Health Promotion 2. Health Education 3. Qualitative research 4. Physical Therapy (Specialty) 5. Cardiology 


\section{INTRODUÇÃO}

Inúmeros estudos têm comprovado que maus hábitos como tabagismo, uso abusivo de álcool e sedentarismo podem provocar ou agravar patologias crônicas como as doenças cardiovasculares, doenças pulmonares, diabetes e osteoartose (Yusuf e Pitt, 2002; Eliasson et al.,2004).

Do contrário, comportamentos saudáveis como não fumar, uso moderado de álcool e prática diária de atividade física, podem preservar a função física do organismo e reduzir o risco de agravamento de pessoas com patologias crônicas (Baumann, 2004; Gool et al., 2007).

A prevenção secundária de doenças cardiovasculares, isto é, em pacientes com doença pré-existente, constitui um importante componente da promoção de saúde nessas populações. Várias estratégias de incentivo a mudanças no estilo de vida são conhecidas, no entanto, muitas vezes a sua prática é dificultada pelas condições sócio-culturais do paciente e a inacessibilidade a programas específicos de educação em saúde para a sua doença (Murchie et al., 2003). Reduzir a difusão das disparidades em saúde na doença cardiovascular é um grande desafio da Saúde Pública (Sanderson et al.,2007).

Quando consideramos indivíduos portadores de doenças crônicas, como por exemplo, a hipertensão arterial sistêmica, a educação em saúde tem um papel importante ao ajudar esses pacientes a conviverem com sua doença, tendo direito de buscar informação do cuidado em saúde, tornandoos assim, capazes de participarem ativamente de seu autocuidado (Smeltzer 
e Bare,1998; Pereira; 2003). Para facilitar o retorno à vida normal, a maioria dos pacientes após o infarto agudo do miocárdio ou após uma cirurgia de revascularização do miocárdio precisa de algumas informações e orientações especiais para as atividades da vida diária, como por exemplo, reassumirem o volante de um automóvel e voltar a trabalhar. A modificação para agir de acordo com as orientações está ligada à compreensão da doença e à necessidade da modificação dos fatores de risco cardiovascular (Pryor e Webber, 2002).

A presença de uma equipe multidisciplinar é fundamental no tratamento dos cardiopatas, uma vez que são necessárias múltiplas ações que envolvem a saúde desses pacientes, e quanto mais o paciente for visto de uma forma integral, mas eficiente e eficaz será seu tratamento, e conseqüentemente melhor será sua qualidade de vida.

A Carta de Ottawa define promoção de saúde (PS) como "o processo de capacitação da comunidade para atuar na melhoria da sua qualidade de vida e saúde, incluindo uma maior participação no controle deste processo" (WHO, 1986). Em Cardiologia, a promoção de saúde é uma ferramenta muito importante e necessária, proporcionando, através de seus conceitos e princípios, ações de prevenção ou sendo incorporado no dia - a - dia do atendimento dos pacientes.

O fisioterapeuta é um dos profissionais de saúde mais atuantes no tratamento de pacientes com doenças cardiovasculares. Este profissional está presente tanto nos períodos pré e pós-operatório de cirurgia cardíaca, quanto durante a fase pós-alta da unidade de terapia intensiva (UTI), 
internação na enfermaria, ambulatório e no acompanhamento dos pacientes. É importante considerar que durante a internação hospitalar há um facilitado acesso do pacientes a informações importantes sobre a evolução da sua doença, tratamento e prevenção, uma vez que, este está em constante contato com profissionais de saúde (Nisbeth et al., 2000).

Há diversas maneiras pelas quais fisioterapeutas poderiam realizar promoção da saúde em um ambiente hospitalar. Podemos destacar, dentre outras: orientações aos pacientes em relação sua patologia, a cirurgia e suas possíveis complicações, ventilação mecânica, recomendações sobre maneiras pelas quais a saúde geral pode ser mantida (dieta adequada, prática de atividade física, controle do peso, fim do tabagismo, moderação ou cessação do consumo de álcool), ensinamento de exercícios respiratórios e motores que podem ser executados pelos próprios pacientes, controle do estresse, orientação dos pacientes a entrarem em contato com programas de educação, recomendações de práticas de atividade física (Regenga, 2000; Pryor e Webber, 2002; Sociedade de Cardiologia do Estado de São Paulo, 2007).

O conhecimento dos fatores de risco para doenças cardiovasculares, somado à urgência em deter o crescimento de doenças crônicas no Brasil, justifica a adoção de estratégias integradas e sustentáveis de promoção da saúde. Estudos sobre o tema são atuais e de extrema importância, na medida em que podem aperfeiçoar a formação profissional do fisioterapeuta, contribuindo para uma melhoria no aumento da eqüidade e integralidade do atendimento em saúde. 


\subsection{EPIDEMIOLOGIA DAS DOENÇAS CARDIOVASCULARES}

As doenças cardiovasculares (DCV) representam um elevado índice de morbi-mortalidade no Brasil e no mundo, sendo a primeira causa de morte em nosso país.

Dados do Ministério da Saúde de 2004 registraram 265 mil mortes por doenças do aparelho circulatório, o que representa $30 \%$ das causas de morte entre os brasileiros (DATASUS, 2004). No SUS, em 2005, as DCV foram responsáveis por 1,8 milhões de internações/ano, com um custo aproximado de 1,32 bilhões de reais.

A identificação dos principais fatores de risco para doenças cardiovasculares através de estudos populacionais e estratégias preventivas, combinando educação em saúde e manuseio direcionado para indivíduos de alto risco, têm contribuído para a queda da mortalidade por doenças cardíacas no mundo (Giannini, 2000; Ford et al.,2007).

Projeções para o ano 2020 indicam que, a doença cardiovascular permanecerá como causa principal de mortalidade e incapacidade, e que a soma de anos de vida perdidos devido à mortalidade prematura e anos vividos com incapacitância ajustados para severidade (DAILYS) atribuídos a ela, se elevarão para cerca de 140-160 milhões, com a maior proporção contribuída por países em desenvolvimento. Este aumento esperado em DCV é reflexo da transição econômica e demográfica dos países em desenvolvimento, como o Brasil, que vive um momento de sobreposição de 
doenças infecciosas e doenças crônico-degenerativas. Dessa maneira, podemos antecipar uma epidemia global de DCV com um impacto substancialmente maior sobre as classes econômicas menos favorecidas.

\section{Fatores de risco cardiovascular}

O termo fator de risco $(\mathrm{FR})$ diz respeito àquelas características que, quando presentes em indivíduos saudáveis, podem se associar de forma independente com a manifestação de uma determinada doença. Pode ser uma característica bioquímica, fisiológica ou estilo de vida modificável, como por exemplo, sedentarismo, ou características pessoais não-modificáveis tais como idade, sexo e história familiar de doença arterial coronariana precoce (Giannini, 2000).

O Estudo de Framingham, realizado na década de 60 nos Estados Unidos, foi o primeiro estudo populacional que identificou diversos fatores de risco para as doenças cardiovasculares, os quais são: hipertensão arterial sistêmica, tabagismo, obesidade, sedentarismo, dislipidemias, diabetes mellitus e antecedentes familiares.

Recentemente comprovou-se outro importante fator de risco cardiovascular: a síndrome metabólica. Esta síndrome é caracterizada pela presença concomitante de mais de um fator de risco num mesmo indivíduo, ou seja, o paciente possui hipertensão arterial, obesidade central, resistência à insulina e dislipidemia (Levantesi et al., 2005;Zeller et al., 2005).

O sedentarismo é responsável pela ocorrência de uma série de doenças crônicas e cada vez mais as pessoas levam uma vida sedentária. $O$ 
combate a esta realidade constitui um importante desafio aos profissionais de saúde, especialmente fisioterapeutas, que trabalham especificamente com exercícios em pacientes e indivíduos saudáveis.

É essencial conhecer a prevalência, na população-alvo, desses fatores de risco, de forma isolada ou combinada, para que as estratégias de prevenção e promoção sejam realizadas de forma real e mais eficaz possível nos serviços de saúde. 


\subsection{FISIOTERAPIA CARDIOVASCULAR}

A Fisioterapia Cardiovascular é uma sub-especialidade da Fisioterapia que tem como objetivo prevenir, manter ou reabilitar as funções de pacientes portadores de doenças cardiovasculares.

A principal atividade do fisioterapeuta cardiovascular é a Reabilitação Cardíaca, que envolve o atendimento do paciente desde a internação hospitalar até a fase ambulatorial do tratamento, e deve compreender além dos exercícios físicos, atividades de educação em saúde, modificação dos fatores de risco cardiovascular e acompanhamento multidisciplinar do paciente.

\subsubsection{REABILITAÇÃO CARDÍACA}

$\mathrm{Na}$ década de 40 surgiram as primeiras indagações relacionadas às condutas preconizadas de repouso prolongado no leito, no tratamento de pacientes portadores de doenças cardiovasculares. Vários estudos demonstraram os benefícios da atividade física para o sistema cardiovascular, e começou a haver uma mudança na prescrição de atividade física no tratamento dos pacientes cardiopatas (Silva e Catai, 2000).

Reabilitação Cardíaca, segundo a Organização Mundial de Saúde, é a soma de atividades necessárias para garantir aos pacientes cardíacos as melhores condições física, mental e social, de forma que eles consigam, 
pelo seu próprio esforço, reconquistar uma posição normal na comunidade e levar uma vida ativa e produtiva (Brown, 1964). É um dos mais importantes componentes na prevenção secundária, especialmente indicada em pacientes com insuficiência cardíaca ou após terem se submetido a diversos tipos de cirurgia cardíaca (valvoplastias, revascularização do miocárdio ou trocas valvares).

Os programas de reabilitação aplicados especialmente a coronariopatas são passíveis de determinar redução dos sintomas de dor precordial e aumento da sobrevida em $20 \%$ a $25 \%$, sobretudo quando realizados após evento coronariano, visando restabelecer as funções cardiovasculares, permitindo ao cardiopata executar atividade física compatível com a capacidade funcional de seu coração (Boesch et al., 2005; Myers, 2003).

Cinco aspectos importantes de um programa bem-sucedido de reabilitação cardíaca incluem: seleção apropriada dos pacientes, terapias médicas, cirúrgicas e farmacológicas concomitantes, educação abrangente dos pacientes, prescrição apropriada dos exercícios e monitoramento minucioso dos pacientes durante a reabilitação (McArdle et al., 2003).

Os principais objetivos e benefícios da reabilitação cardíaca são: identificação e tratamento dos fatores de risco; otimização da condição física; facilitação ao retorno e atividades ocupacionais; preparação do indivíduo e sua família para um estilo de vida que possa reduzir os riscos de doença arterial coronariana e cardiopatia hipertensiva, além da reversão dos 
efeitos adversos do descondicionamento fisiológico, resultante de um estilo de vida sedentário (Regenga, 2000; Umeda, 2005).

O fisioterapeuta concentra-se, principalmente, nos aspectos físicos da recuperação, especialmente minimizando os efeitos da perda de condicionamento físico, prejudicado pelo repouso no leito, e intensificando o funcionamento cardiovascular e músculo-esquelético. Inicialmente realizará a avaliação, e, em seguida, prescrição de exercícios respiratórios e exercícios assistidos ou ativos para alguns pacientes, deambulação supervisionada, subidas de escadas e outras atividades. A orientação ao exercício, a automonitorização, e uma descrição de atividades para serem feitas em casa, são importantes componentes do tratamento do paciente (Pryor, 2002).

Com o intuito de adquirir bons níveis de capacidade funcional e de qualidade de vida, a reabilitação cardíaca não deve ser simplesmente a prática de exercícios, devendo também incluir a educação e orientação, de modo que o paciente torne-se responsável por grande parte de seu próprio tratamento. O Lifestyle Heart Trial foi o primeiro estudo randomizado e controlado a mostrar que, pacientes fora do ambiente hospitalar, podem ser motivados a fazer e sustentar mudanças no estilo de vida, com regressão de aterosclerose no período de um ano (Negrão, 2005).

A reabilitação cardíaca é, com freqüência, dividida em quatro períodos que variam de paciente para paciente. Eles são definidos na literatura americana e australiana como: fase I - o tempo do tratamento hospitalar; fase II: recuperação do paciente não-hospitalizado; fase III - manutenção em 
longo prazo e fase IV como fase de manutenção ou condicionamento (Pryor e Webber, 2002; Negrão, 2005).

Para a American Heart Association, os programas de Reabilitação devem ser compostos por uma equipe multidisciplinar (médicos, enfermeiros, fisioterapeutas, educadores físicos, nutricionistas e psicólogos), visto que estaremos tratando de doença ou enfermidade multifatorial (Balady et al., 2000).

Alguns estudo já mostraram a presença de depressão e seus sintomas, etilismo e prevalência de obesidade em pacientes pós infarto do miocárdio (Milani et al., 1996; Milani e Lavie, 1998; Pinheiro et al., 2007). Apesar do foco da reabilitação ser o exercício físico, ele por si só não deve ser o foco da reabilitação, é primordial observar a presença de outros fatores de risco não tão convencionais que podem estar presentes nesses pacientes.

\section{Reabilitação não supervisionada}

Devemos considerar a possibilidade que a reabilitação cardiovascular seja aplicada por meio da reabilitação não supervisionada ou parcialmente supervisionada, visto que existe uma escassez de centros que oferecem a reabilitação cardiovascular, gerando uma grande demanda de pacientes que não tem a oportunidade de realizá-la.

A Diretriz de Reabilitação Cardiopulmonar e Metabólica recomenda que se deva manter a prescrição individual de exercícios, com o fisioterapeuta e/ou professor de educação física realizando uma demonstração prática em sessões formais de condicionamento físico, contemplando todas as etapas 
de uma sessão de reabilitação ambulatorial convencional (aquecimento, exercícios aeróbicos e alongamento e/ou relaxamento final). $\mathrm{O}$ atendimento na reabilitação não-supervisionada tem objetivos de adoção e manutenção da prática de exercícios físicos (Carvalho, 2006).

\section{Modificação dos fatores de risco}

A modificação dos fatores de risco pode ser um dos principais benefícios da reabilitação cardíaca.

O exercício aumenta as lipoproteínas de baixa densidade e os triglicerídeos, com pequenas alterações de colesterol total. Em pacientes obesos tais benefícios são ainda maiores, quando associados à perda de peso. Aumentos no nível de atividade física melhoram a sensibilidade à insulina, muitas vezes prevenindo o diabetes mellitus não insulinodependente. $\mathrm{O}$ exercício de resistência intenso em pessoas mais velhas melhora a fibrinólise, possivelmente reduzindo os riscos de trombose aguda (Frontera et al.,1999).

Os mecanismos fisiológicos responsáveis pela redução da pressão arterial sistólica, em hipertensos submetidos ao condicionamento físico, não são ainda bem conhecidos. Como efeito do exercício realizado de modo regular, tem sido demonstrado diminuição da resposta de pressão arterial, dos níveis de noradrenalina circulantes, e redução da resistência vascular periférica (Monteiro, 2004).

Além desses efeitos sobre os fatores de risco, algumas outras possíveis ações são atribuídas ao condicionamento físico e têm particular importância 
em portadores de doença coronariana. Entre estas ações, destacam-se: redução da coagulação sangüínea, redução da isquemia e aumento da tolerância à angina induzidos pelo exercício. A soma destes benefícios poderia retardar a evolução da aterosclerose e diminuir o risco relacionado a esta condição (Alfieri et al., 2002). 


\subsection{PROMOÇÃO DA SAÚDE}

O conceito tradicional de promoção de saúde (PS) foi proposto, inicialmente, por Leavell e Clark, em meados do século $\mathrm{XX}$, ao desenvolverem o modelo de história natural da doença.

A partir desta perspectiva da história natural, Leavell e Clark propuseram medidas de intervenção nos diferentes estágios da doença, em três diferentes níveis de aplicação de medidas preventivas: a Prevenção Primária, ou primeiro nível, que abrange promoção da saúde e medidas de proteção específica; Prevenção Secundária, com diagnóstico e tratamento precoce, e limitação da validez, e a Prevenção Terciária, que consiste na reabilitação (Leavell e Clark,1976).

O conceito de promoção da saúde aparece como um dos níveis da prevenção primária, definido como "medidas destinadas a desenvolver uma saúde ótima". Alguns procedimentos são apontados por eles como importantes, tais como: nutrição adequada, boa educação, prevenção de doenças sexualmente transmissíveis, lazer, boas condições de trabalho, boa moradia, realização de exames periódicos. Trata-se, portanto, de ações que visam o indivíduo, o que é exatamente o oposto do conceito atual de promoção da saúde que visa o coletivo, o bem comum (Buss, 2003; Westphal, 2006). 
Este conceito de promoção da saúde se modificou e se desenvolveu de forma mais vigorosa nos últimos 25 anos, nos países desenvolvidos, particularmente no Canadá, nos Estados Unidos e nos países da Europa Ocidental (Buss, 2003).

Em 1974, com o Informe Lalonde, surge o movimento moderno da promoção de saúde, no Canadá. Os conceitos de "campo de saúde" deste relatório são classificados em quatro partes: a biologia humana (fatores genéticos e função humana); ambiente (natural e social); estilo de vida e organização dos serviços de saúde (Lalonde, 1974). Apesar da evolução de conceitos, o foco deste relatório era a mudança de estilos de vida, com ênfase no indivíduo, o que nos indica perspectivas comportamentais, baseadas na prevenção.

A I Conferência Internacional sobre Promoção da Saúde, realizada em 1986, teve como principal resultado a Carta de Ottawa, que se tornou desde então, referência básica e fundamental no desenvolvimento dos preceitos de promoção da saúde em todo o mundo.

A Carta de Ottawa define PS como "o processo de capacitação da comunidade para atuar na melhoria da sua qualidade de vida e saúde, incluindo uma maior participação no controle deste processo", enfatiza a importância da promoção à saúde e considera, principalmente, a influência dos fatores sociais sobre a saúde dos indivíduos e população (WHO,1986).

Depois das várias conferências internacionais sobre Promoção da Saúde, a Organização Mundial de Saúde (OMS) preconizou os seguintes princípios caracterizadores de ações de PS: (1) Concepção holística de 
saúde: ações devem se voltar para múltiplas causas do processo saúdedoença, fomentando o indivíduo em sua saúde física, mental, social e espiritual, (2) Eqüidade: criação de oportunidades iguais para que todos tenham saúde, o que está diretamente relacionado com a distribuição dos determinantes de saúde na população (renda, habitação, educação), (3) Intersetorialidade: compreendida amplamente como a articulação dos serviços de saúde, (4) Participação social: juntamente com o "empowerment", são considerados elementos-chave, e a participação social efetiva e concreta estabelecida como objetivo primordial da promoção da saúde é compreendida como o envolvimento dos atores diretamente interessados - membros da comunidade e organizações afins, formuladores de políticas, profissionais de saúde no processo de tomada de decisões, implementação e avaliação de políticas públicas e (5) Sustentabilidade: refere-se à continuidade das políticas públicas, e que em promoção da saúde, seria especialmente importantes tendo em vista que as iniciativas dessa área dirigem-se a questões de natureza complexa, envolvendo processos de transformação coletivos, com impactos a médio e longo prazo (Sícoli e Nascimento, 2003 ; Westphal; 2006).

É importante revisitar os cinco campos de ação da Promoção da saúde inscritos na Carta de Ottawa. São eles:

1. Construção de políticas públicas saudáveis: A saúde deve ser prioridade na agenda de políticos e dirigentes, ação que aponta para a eqüidade em saúde, distribuição mais eqüitativa de renda e políticas sociais. No Brasil, podemos citar como exemplos de políticas saudáveis o Estatuto 
da Criança e do Adolescente, a Política Nacional de Trânsito e a Política Nacional de Promoção da Saúde.

2. Reforço da ação comunitária: Envolve a participação da comunidade, atores do Estado e sociedade civil, no desenvolvimento das prioridades, tomada de decisões, definição e implementação de estratégias de promoção da saúde que visem incrementar o poder das comunidades.

3. Criação de ambientes saudáveis: É necessário que exista uma preocupação com a saúde dentro de relações entre população e meio ambiente. A comunidade deve refletir sobre problemas e potencialidades nos espaços de convivência - escolas, hospitais, unidades de saúde, locais de trabalho e lazer - com o intuito de fazê-los mais produtivos e saudáveis.

4. Desenvolvimento de habilidades pessoais: Através da divulgação de informação, estratégias educativas e intensificação das habilidades vitais, possibilitando e capacitando os indivíduos a um maior controle sobre sua saúde.

5. Reorientação dos serviços de saúde: Representa a ampliação de acesso aos serviços de saúde, através do incremento das atividades preventivas através da abordagem e conceitos da promoção de saúde. 0 papel do setor saúde deve mover-se, gradativamente, no sentido de ampliar e promover a saúde dos indivíduos e pacientes, além de suas responsabilidades cotidianas, como provimento de serviços clínicos e de urgência.

O conceito de PS da Carta de Ottawa difere do conceito de Leavell e Clark na medida em que valoriza a autonomia e a participação do indivíduo e 
da comunidade no processo de alcance e melhora de sua saúde, e, também porque, segundo os campos de ação propostos pela Carta, diversos são os responsáveis pela promoção: o indivíduo, a comunidade, os serviços de saúde e o setor político.

Segundo Campos et al (2004), para falar de promoção da saúde no Brasil, é necessário fazer uma reflexão sobre a criação e luta contínua do campo da Saúde Coletiva pela melhoria do Sistema Único de Saúde (SUS). É também indissociável dentro deste contexto, o enfrentamento de iniqüidades históricas de grandes proporções no Brasil, que impõem desafios cotidianos não só ao setor saúde, mas a todos aqueles que constroem políticas públicas.

Em 2006, o Ministério da Saúde propôs a criação da Política Nacional de Promoção da Saúde (PNPS), que tinha como objetivo geral promover a qualidade de vida e reduzir vulnerabilidade e riscos à saúde, relacionados aos seus determinantes e condicionantes - modos de viver, condições de trabalho, habitação, ambiente, educação, lazer, cultura, acesso a bens e serviços essenciais (Brasil, 2006).

As ações específicas propostas pela PNPS para o biênio 2006-2007 foram voltadas a:

- divulgação e implementação da PNPS

- alimentação saudável

- prática corporal/ atividade física

- prevenção e controle do tabagismo 
- redução da morbi-mortalidade em decorrência do uso abusivo de álcool e outras drogas

- redução da morbi-mortalidade por acidentes de trânsito

- prevenção da violência e estímulo à cultura de paz

- promoção do desenvolvimento sustentável

A temática da PS é bastante atual, e cada vez mais vem ganhando espaço nas pesquisas e dentro do campo da Saúde Coletiva, procurando enfatizar ações positivas relacionadas à saúde, tanto individual como coletiva, diferentemente do modelo de atenção em saúde centrado na assistência individual e curativa.

A promoção de saúde constitui um instrumento promissor para enfrentamento dos diversos problemas de saúde que afetam as comunidades. Propõe a articulação e envolvimento de saberes entre profissionais e população, para enfrentamento e resolução de questões em busca de uma qualidade de vida cada vez maior.

O presente estudo utilizará como referencial teórico as definições e os conceitos preconizados pela Carta de Ottawa (1986) para análise e discussão dos dados. Daremos enfoque especial a um campo de ação da Promoção da saúde: o desenvolvimento de habilidades pessoais, na medida em que investigamos as percepções e o autocuidado dos pacientes que estão recebendo as atividades e a contribuição destas ações do hospital neste contexto. 


\subsubsection{EDUCAÇÃO EM SAÚdE E ESTRATÉGIAS DE INTERVENÇÃO E CONTROLE DE DOENÇAS CARDIOVASCULARES}

Entende-se por educação em saúde combinações de experiências de aprendizagem delineadas, que visam facilitar ações voluntárias que conduzem à saúde (Candeias, 1997).

A partir de 1960 no Brasil, algumas atividades de educação em saúde vêm sendo baseada na pedagogia da problematização, resgatando as idéias de Paulo Freire e outros educadores da mesma ideologia. Para Freire (1969), o propósito da educação é a libertação humana, ou seja, as pessoas passam a ser sujeitos do seu próprio aprendizado. Suas reflexões baseavam-se nos processos de educação participativa e emancipatória, nas quais as pessoas são capazes de pontuar problemas e criar soluções, transformando-se e modificando realidades opressoras.

A educação em saúde atendendo à perspectiva ampla da promoção da saúde precisa considerar a humanidade dos envolvidos, o conhecimento popular, o seu valor específico e sua potencialidade de transformar e ser transformado em contato com o conhecimento da ciência (Westphal,1998).

A educação em saúde é um importante instrumento que pode e deve ser usado com o intuito de aumentar o autocuidado e a saúde dos indivíduos. É importante que as ações de educação em saúde, para serem realmente eficazes, devam considerar as perspectivas e anseios dos indivíduos, devam ser problematizadoras e terem o diálogo como base, levando em conta a realidade na qual a população está inserida. 
Especificamente no combate às doenças cardiovasculares, aonde os fatores de risco modificáveis desempenham um papel determinante no seu aparecimento, a educação é uma importante ferramenta dos profissionais de saúde.

Pesquisas e experiências realizadas em diversos países, e com êxito na reversão e mudanças positivas nas tendências de morbi-mortalidade por DCV, demonstram que alguns aspectos são essenciais para 0 desenvolvimento de estratégias efetivas de promoção da saúde nesta área:

- a maioria dos fatores de risco influencia durante o curso de vida dos indivíduos, com intensidades variáveis;

- a aquisição de hábitos saudáveis de vida tem retorno direto sobre a saúde do indivíduo, em qualquer época da vida, e sobre qualquer condição preexistente de saúde;

- o ambiente físico, socioeconômico e cultural, tem ampla influência sobre comportamento e estilo de vida de indivíduos;

- as medidas de intervenção nas comunidades devem ter sustentabilidade a longo prazo, e devem incluir, especialmente, aqueles com menores possibilidades de escolha em razão da pobreza e da exclusão social; e

- a parceria entre atores sociais e econômicos, locais e nacionais, é necessária para intervenções sustentáveis (Marmot, 2001; Lenfant, 2001; Yusuf, 2002). 


\subsection{O FISIOTERAPEUTA COMO PROMOTOR DE SAÚDE}

A Fisioterapia no Brasil, reconhecida como profissão, é relativamente nova, quando comparada a outras áreas da saúde, como Medicina e Enfermagem.

Frente a acontecimentos mundiais, como as epidemias de poliomielite e as grandes guerras, com um grande número de seqüelados e deficientes físicos, houve uma necessidade de melhoria na formação dos fisioterapeutas, anteriormente considerados profissionais de nível técnico (Rebelatto e Botomé, 1999).

No Brasil, o curso de Fisioterapia é fundamentado pelas Diretrizes Curriculares Nacionais para o ensino de graduação em Fisioterapia, instituída pela resolução CNE/CES no 4 , de 19 de fevereiro de 2002. De acordo com estas diretrizes, o profissional fisioterapeuta egresso da universidade tem um perfil generalista, humanista, crítico e reflexivo, e é capaz de atuar em todos os níveis de atenção em saúde, com base no rigor científico e intelectual.

O objetivo universal da Fisioterapia é identificar e maximizar o potencial do movimento humano dentro das esferas de promoção, prevenção, tratamento e reabilitação. No entanto, existe uma tendência do ensino superior em Fisioterapia na valorização do individual, do tratamento e reabilitação, e na utilização de métodos e técnicas avançadas. Isto reflete no 
profissional que atua nos serviços de saúde, e o que vemos na prática clínica, são fisioterapeutas essencialmente reabilitadores.

Uma definição mais completa e moderna, da American Physical Therapy Association (APTA), diz que Fisioterapia é uma "profissão da saúde, cujo principal objetivo é a promoção da saúde e da função, por meio da aplicação de princípios científicos para evitar, identificar, avaliar, corrigir ou minimizar a disfunção aguda ou crônica dos movimentos" (Augustine, 2000).

Embora fisioterapeutas devam estar comprometidos em promover atividade física e o exercício, na prática os serviços de Fisioterapia geralmente focam na recuperação e manutenção da função e qualidade de vida nos indivíduos com perdas e distúrbios de movimento.

Existem áreas dentro da Fisioterapia, já consagradas como áreas de "prevenção" e "promoção da saúde", como por exemplo, a prevenção de lesões por esforços repetitivos (LER) e doenças osteomusculares relacionadas ao trabalho (DORT). O trabalho e especificidades do profissional da área estão bem estabelecidos dentro de empresas e locais de trabalho (Dias, 2001; Ruiz, 2003). Outra área que vem crescendo bastante dentro da Fisioterapia, e que tem destaque na promoção de saúde, é o trabalho dos fisioterapeutas com as gestantes antes, durante e após o parto.

$\mathrm{Na}$ área de Fisioterapia Cardiovascular o fisioterapeuta atua bastante na Reabilitação Cardíaca, durante a fase intra-hospitalar e ambulatorial. O seu papel como promotor de atividade física e como educador em saúde ainda é bastante tímido, e precisa ainda ser ampliado e explorado. Devido a 
sua formação e experiência, o potencial do fisioterapeuta para atuar preventivamente, antes das doenças cardiovasculares se instalarem é muito grande. E, mesmo na prevenção secundária e terciária, o papel do fisioterapeuta na manutenção da saúde através de exercícios e atividades de educação em saúde é indiscutível, porém pouco desenvolvido. 


\section{OBJETIVOS}

Geral:

- Identificar as ações relacionadas à Promoção da Saúde realizadas pelo serviço de Fisioterapia em uma instituição de referência em Cardiologia e verificar as percepções de profissionais e pacientes neste contexto

\section{Específicos:}

- Descrever as ações realizadas por fisioterapeutas relacionadas à Promoção da Saúde durante todo o atendimento do paciente cardiopata

- Propor um protocolo de ações de Promoção da Saúde em Cardiologia 


\section{MÉTODOS}

\subsection{Caracterização do estudo}

O presente estudo se caracteriza como uma pesquisa qualitativa, que possui como temática Práticas de promoção da saúde em uma instituição hospitalar de referência em Cardiologia. Nossa intenção inicial era fazer o estudo em três hospitais de referência em Cardiologia, mas em um contato inicial em um dos hospitais, conversamos com o chefe do setor que nos explicou como era a rotina de atendimento relacionada ao setor de Fisioterapia, e constatamos que os objetivos do estudo não seriam alcançados, visto que não havia ações de promoção de saúde oferecida pelo setor.

No outro hospital contatado, não nos foi permitido a realização da pesquisa, não nos sendo revelados os motivos. Desta forma, optamos pelo estudo de caso único da instituição, aprofundando o estudo através de mais de uma forma de coleta de dados, que descreveremos a seguir.

\subsection{Local do estudo}

O estudo foi realizado em um hospital de referência em Cardiologia, localizado no município de São Paulo - SP. Para que se entenda o porquê da escolha desta instituição como local de estudo, faz-se necessário entender alguns aspectos e números relativos ao funcionamento e importância no contexto de atendimento de Fisioterapia deste hospital no 
município de São Paulo. O nome da instituição foi preservado por motivos éticos.

\subsubsection{A instituição hospitalar}

A escolha da instituição foi justificada pela grande referência do hospital na área de Cardiologia, e em especial, porque o hospital se destaca na área de Fisioterapia Cardiovascular, e fazia-se necessário uma plena atuação do fisioterapeuta nesta área, visto que um dos objetivos era correlacionar a área de reabilitação com a promoção da saúde, focando ações de fisioterapeutas.

A instituição pertence à secretaria de saúde do estado de São Paulo, e atende pacientes da rede pública de saúde. São pacientes que necessitam de atendimento de urgência, cirurgias ou tratamento ambulatorial em Cardiologia. O perfil destes pacientes é bastante variável, variando de crianças a idosos, com diversas patologias (hipertensão arterial, insuficiência cardíaca, infarto do miocárdio, síndrome metabólica, e até transplantes cardíacos).

A grande maioria dos pacientes é de baixa renda, são pessoas carentes, que necessitam muito de atendimento médico e ambulatorial. Como veremos a seguir, o setor de Fisioterapia atende muitos pacientes ao mês, conta com poucos profissionais e a demanda é muito grande.

\section{Alguns números do serviço de Fisioterapia no mês de Julho/2008}

$\mathrm{Na}$ Unidade Coronariana foram realizados 126 atendimentos fisioterapêuticos (Gráfico 1), sendo 45 atendimentos de fisioterapia 
motora/reabilitação cardíaca e 81 atendimentos de fisioterapia respiratória. (Gráfico 2).

$\mathrm{Na}$ enfermaria de insuficiência cardíaca, foram realizados 786 atendimentos fisioterapêuticos (Gráfico 1), sendo 597 atendimentos de fisioterapia motora/reabilitação cardíaca e 189 atendimentos de fisioterapia respiratória (Gráfico 2).

No ambulatório de hipertensão arterial foram realizadas 154 sessões que incluem atividades com dois grupos de pacientes que realizam atividades físicas, e 42 consultas individuais com fisioterapeuta no ambulatório.

$\mathrm{Na}$ enfermaria do pós-operatório de transplantes cardíaco foram realizados 68 atendimentos fisioterapêuticos (Gráfico 1), sendo 23 atendimentos de fisioterapia motora/reabilitação cardíaca e 45 atendimentos de fisioterapia respiratória (Gráfico 2).

Gráfico 1: Número total de atendimentos do Serviço de Fisioterapia em julho/2008

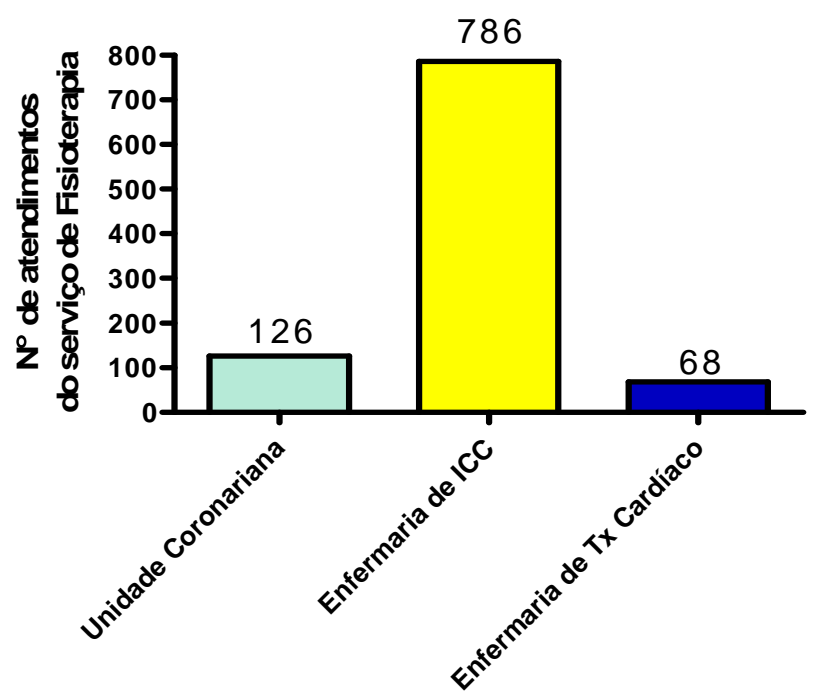




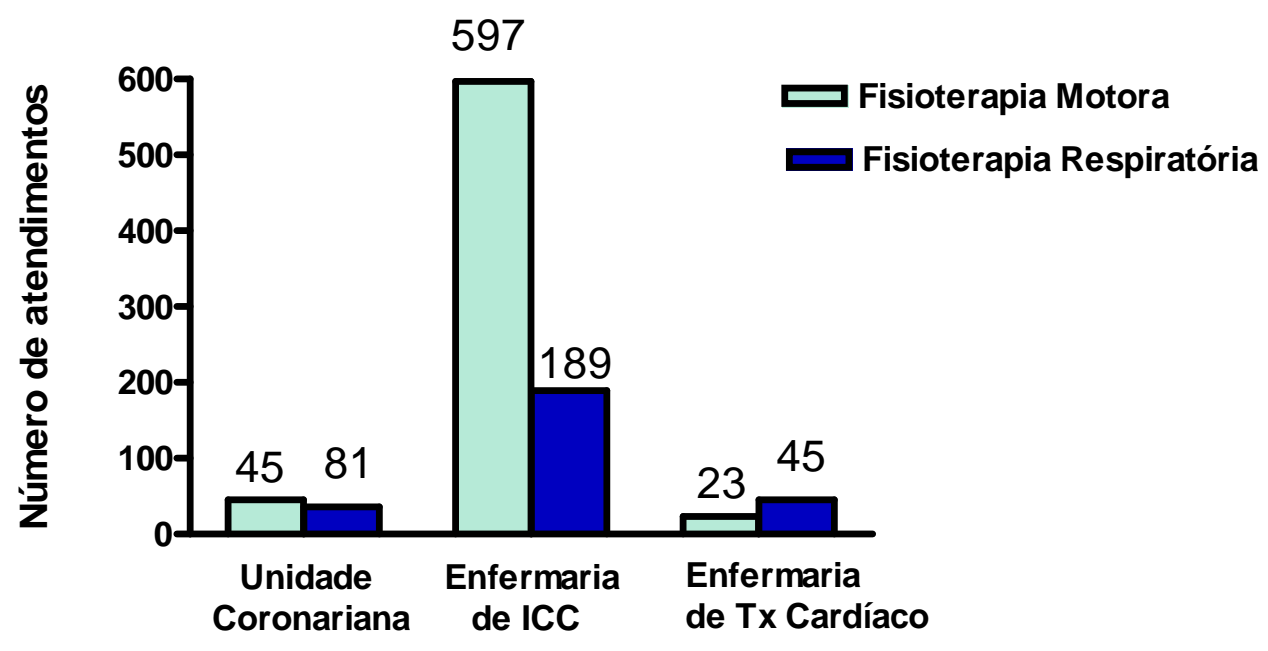

Existiam no quadro fixo do setor dez profissionais fisioterapeutas plantonistas, e o hospital recebia dez residentes de Fisioterapia Cardiovascular anualmente. Esses residentes eram supervisionados pelos fisioterapeutas fixos e passavam por treinamento em todos os setores do Departamento de Fisioterapia dentre os quais: Unidade Coronariana (UCO), enfermarias (pré e pós operatório de cirurgia cardíaca), ambulatórios de hipertensão arterial e de reabilitação cardíaca.

\subsection{Entrada no campo de estudo}

Antes de começar a pesquisa, e até mesmo para solicitar o consentimento do chefe do setor de Fisioterapia da instituição, foi realizada 
uma reunião inicial com o mesmo, na qual foram esclarecidos quais os objetivos da pesquisa e qual seria a forma de coleta de dados.

Nesta mesma reunião, foi realizada uma mini-entrevista, a qual se fazia necessária, para saber se o hospital oferecia ações de promoção da saúde aos pacientes e para a comunidade em geral, quais seriam elas e se o fisioterapeuta estava presente nestas ações. Desta forma, o projeto foi entregue ao chefe do setor de Fisioterapia, e encaminhado ao Comitê de Ética em pesquisa da instituição, com o devido consentimento do mesmo para a realização do estudo (Apêndice 04).

\subsubsection{Sujeitos da pesquisa}

Os sujeitos da pesquisa foram oito fisioterapeutas que trabalhavam na instituição, dentre estes o chefe do setor de Fisioterapia, e sete pacientes da instituição.

Os setes pacientes entrevistados faziam tratamento no hospital no momento da coleta de dados e foram selecionados através de um critério único de participar ou ter participado de uma ou mais ações de promoção de saúde. Deveriam estar dispostos e aceitarem responder a entrevista e possuir um nível de consciência e orientação adequadas . Estes pacientes foram identificados através dos números um a sete e serão apresentados no capítulo resultados e discussão. 
Os sete fisioterapeutas observados e entrevistados trabalhavam na instituição e participam ou já haviam participado de uma ou mais ações de promoção de saúde oferecidas pelo hospital.

\subsection{O trabalho de campo}

Para Becker (1994), o cientista social que realiza um estudo de caso de uma comunidade ou organização pode fazer uso do método de observação participante em uma de suas muitas variações, muitas vezes em ligação com outros métodos mais estruturados, tais como entrevistas. Foram utilizadas para a coleta de dados estas duas técnicas, a entrevista e a observação, que se complementaram e permitiram uma compreensão maior do caso em estudo.

O trabalho de campo foi realizado em aproximadamente três meses, com intervalos entre eles, devido à dinâmica do curso de mestrado (disciplinas, cursos, simpósios), e das próprias ações de atendimento do hospital. Iniciou-se em julho de 2008 e encerrou-se em abril de 2009.

Para a coleta de dados, realizamos a triangulação metodológica, que, segundo Denzin (1978), é a inserção de múltiplas técnicas, observadores e métodos para ampliar as referências e a visão sobre a realidade social em investigação.

A triangulação geralmente tem sido considerada um processo que utiliza múltiplas percepções para esclarecer os significados e verificar a reprodutibilidade de uma observação ou interpretação. Mas, reconhecendo que as observações ou interpretações não são perfeitamente reproduzíveis, 
a triangulação serve também para esclarecer significados através da identificação de diferentes maneiras do fenômeno que está sendo estudado. Em estudos de caso, isto pode ser feito utilizando várias fontes de dados (Yin, 1984).

\subsubsection{A observação}

Durante o trabalho de campo, foi realizada uma observação participante, na qual o expectador mantém certa distância do objeto, priorizando observação à participação (Cruz Neto, 1997). Em algumas ações era impossível passar despercebida, inclusive porque muitos pacientes já eram acostumados uns com os outros e com os próprios profissionais.

Cogitou-se inicialmente fazer somente uma entrevista com os profissionais e pacientes sobre as ações de promoção de saúde, mas para se aproximar do cotidiano, atendimento e realização destas ações, optou-se por realizar também a observação. Além disso, um dos objetivos da pesquisa foi propor um protocolo baseado no que foi visto e no que podia ou não ser melhorado, e nada substitui o contato com a realidade e possíveis mudanças da mesma.

Vale ressaltar que observamos as ações que eram realizadas em grupo, por uma equipe multidisciplinar, ou com a presença somente do fisioterapeuta com os pacientes. No caso dos atendimentos que o fisioterapeuta realizava individualmente, como por exemplo, na consulta individual com o paciente no ambulatório de hipertensão, estes não foram 
considerados, uma vez que podiam ser modificados no momento da observação.

A observação seguia um roteiro inicial, e seu registro foi feito em um diário de campo, que continha além de questões objetivas, questões de natureza reflexiva da pesquisadora.

\subsubsection{Entrevistas}

A entrevista semi-estruturada contém perguntas abertas e fechadas em seu roteiro, permitindo certa "liberdade" ao entrevistado, de forma que este pode se expressar sobre o tema, sem respostas pré-impostas por questões fechadas (Minayo, 2000).

Foram realizadas entrevistas semi-estruturadas, baseadas em dois roteiros prévios, um para a entrevista com os fisioterapeutas (apêndice 5) e o outro para entrevista com os pacientes (apêndice 6), contendo questões norteadoras ao tema e aos propósitos da pesquisa.

As entrevistas com os fisioterapeutas não foram agendadas previamente. Logo após a observação, o profissional era abordado e convidado a responder à entrevista. Os profissionais já sabiam da realização da pesquisa no setor, então esse contato foi tranqüilo e natural. As entrevistas foram realizadas na sala do chefe do setor de Fisioterapia e tiveram duração média de aproximadamente meia hora cada.

O roteiro da entrevista com os fisioterapeutas continha questões relacionadas às ações de promoção de saúde de um modo geral; ações de promoção de saúde que o hospital oferecia; barreiras ou obstáculos 
relacionados à realização destas ações; as dificuldades ou não, que os pacientes apresentavam para adesão ao seu tratamento, baseados em sua experiência, e como estava a percepção destes profissionais em relação ao autocuidado dos pacientes.

As entrevistas com os pacientes foram realizadas em duas situações distintas: na primeira, os pacientes estavam internados no hospital, então foram feitas à beira do leito; e na segunda situação, os pacientes faziam tratamento ambulatorial, portanto não estavam internados, e responderam à entrevista em uma sala do ambulatório de hipertensão arterial. Estas entrevistas tiveram uma duração média de aproximadamente quarenta minutos cada. É importante ressaltar que os pacientes internados e que responderam à entrevista estavam estáveis clinicamente, bem orientados, conscientes e todos esperam receber alta hospitalar brevemente.

O roteiro da entrevista com os pacientes continha questões relacionadas a seu tratamento, quais atividades participava ou participou no hospital, de que forma essas ações de promoção de saúde acrescentaram algo de positivo em sua saúde e seu tratamento, se existiam dificuldades em seu autocuidado e como estes pacientes percebiam as mudanças em seu estilo de vida, antes e após a entrada na instituição.

Todas as entrevistas foram gravadas em aparelho digital com a anuência dos sujeitos, armazenadas pela pesquisadora, e, logo após sua realização, transcritas pela mesma. 


\title{
3.5. Análise dos dados
}

Posteriormente à fase de trabalho de campo e coleta de dados, registros no diário de campo e transcrição das entrevistas, realizou-se uma leitura exaustiva de todo aquele material com o intuito de compreender aquele estudo de caso e suas peculiaridades, e aquele material das entrevistas foi analisado segundo a técnica da Análise Temática.

De acordo com Minayo (2000):

\begin{abstract}
Fazer uma análise temática consiste em descobrir os núcleos de sentido que compõem uma comunicação cuja presença ou freqüência signifiquem alguma coisa para o objetivo analítico visado. [..] a presença de determinados temas denota os valores de referência e os modelos de comportamento presentes no discurso.
\end{abstract}

Através de análise das leituras das falas e anotações da observação, procurou-se extrair os temas e situações de maior importância e que pudessem responder às questões iniciais da pesquisa.

A análise temática segue 3 etapas: A pré-análise, exploração do material e tratamento dos resultados obtidos e interpretação. Seguindo todo estes procedimentos metodológicos emergiram dois grandes temas: "A visão dos profissionais frente à promoção da saúde" e "As ações de promoção de saúde e o autocuidado dos pacientes: convivendo com uma doença crônica"

\subsection{Aspectos Éticos}

Os profissionais e pacientes foram abordados individualmente pelo pesquisador responsável. Foram explicados todos os procedimentos e 
objetivos, assim como os benefícios do estudo, que todo dado colhido ou fornecido por ele seria mantido em sigilo absoluto, e após sua autorização, eles assinaram o termo de consentimento (Apêndice 03). Dessa maneira, os direitos do profissional e paciente, e a ética da pesquisa foram preservados como preconiza a Resolução 196/96 do Conselho Nacional de Saúde (Conselho Nacional de Saúde,1996),órgão que rege a pesquisa em seres humanos no Brasil e a Declaração de Helsinki (World Medical Association, 1997).

O presente projeto de pesquisa foi encaminhado e aprovado pela Comissão de Ética para análise de projetos de pesquisa - CAPPesq do Hospital das Clínicas da Faculdade de Medicina da Universidade de São Paulo, cadastrado sob o número 1217/07, bem como aprovado pelo comitê de ética do hospital, cadastrado sob o número 3786 e o estudo só teve início após a aprovação por estes comitês. Optamos por preservar o nome da instituição hospitalar na qual foi realizada a pesquisa. 


\section{RESULTADOS E DISCUSSÃO}

\subsection{As ações de promoção de saúde oferecidas pela instituição}

Após entrevista com a coordenadora do serviço de Fisioterapia da instituição e estágio de observação e acompanhamento dos fisioterapeutas, verificamos que o setor possui sete atividades de promoção da saúde

oferecidas aos pacientes. Algumas atividades possuem uma equipe multidisciplinar, na qual o papel do fisioterapeuta está bem estabelecido, e em outras somente os fisioterapeutas estão envolvidos.

Dentre as atividades de promoção da saúde realizadas pelos fisioterapeutas estão:

1) Aula mensal: tratamento da hipertensão arterial

2) Aula quinzenal de pré e pós-operatório de cirurgia cardíaca

3) Grupos de atividade física (3x/semana)

4) Programa Anti-Tabagismo

5) Reabilitação Cardíaca

6) Dias temáticos (Combate ao Tabagismo e da Hipertensão)

7) Grupo GLPP * ( ${ }^{*}$ Glicemia, Peso, Lípides, Pressão e Peso)

Na página seguinte, o quadro 1 mostra um resumo das atividades de promoção de saúde oferecidas pelo hospital, qual o setor do hospital responsável pela atividade, quais os profissionais presentes em cada uma, qual o público-alvo e o objetivo de cada ação. 
Quadro1: Resumo das atividades de promoção da saúde realizadas por fisioterapeutas na instituição

\begin{tabular}{|c|c|c|c|c|}
\hline ATIVIDADES & $\begin{array}{c}\text { SETOR DO } \\
\text { HOSPITALQUE } \\
\text { PROMOVE }\end{array}$ & $\begin{array}{l}\text { PROFISSIONAIS } \\
\text { ENVOLVIDOS }\end{array}$ & $\begin{array}{l}\text { PÚBLICO- } \\
\text { ALVO }\end{array}$ & OBJETIVOS \\
\hline $\begin{array}{l}\text { Aula mensal: } \\
\text { tratamento da } \\
\text { hipertensão } \\
\text { arterial }\end{array}$ & $\begin{array}{c}\text { Ambulatório de } \\
\text { Hipertensão Arterial }\end{array}$ & $\begin{array}{l}\text { Cardiologista, } \\
\text { fisioterapeuta, psicóloga, } \\
\text { nutricionista e enfermeira }\end{array}$ & Hipertensos & $\begin{array}{l}\quad \text { Orientação } \\
\text { relacionada ao } \\
\text { controle e } \\
\text { tratamento dos } \\
\text { fatores de risco } \\
\text { para a } \\
\text { hipertensão } \\
\text { arterial }\end{array}$ \\
\hline $\begin{array}{l}\quad \text { Aula quinzenal } \\
\text { de pré e pós- } \\
\text { operatório de } \\
\text { cirurgia cardíaca }\end{array}$ & $\begin{array}{l}\text { Serviço de } \\
\text { Fisioterapia }\end{array}$ & Fisioterapeuta & $\begin{array}{l}\text { Coronariopatas, } \\
\text { valvopatas }\end{array}$ & \begin{tabular}{lr}
\multicolumn{3}{c}{ Orientações } \\
pré e pós \\
operatórias, \\
demonstrar os \\
benefícios e a \\
importância dos \\
exercícios físicos
\end{tabular} \\
\hline $\begin{array}{l}\text { Grupo de } \\
\text { atividade física } \\
(3 x \text { /semana })\end{array}$ & $\begin{array}{l}\text { Ambulatório de } \\
\text { Hipertensão Arterial }\end{array}$ & Fisioterapeuta & Hipertensos & $\begin{array}{l}\quad \text { Controle da } \\
\text { pressão arterial } \\
\text { através dos } \\
\text { exercícios }\end{array}$ \\
\hline $\begin{array}{l}\text { Programa Anti- } \\
\text { Tabagismo }\end{array}$ & $\begin{array}{l}\text { Ambulatório de } \\
\text { Hipertensão Arterial }\end{array}$ & $\begin{array}{l}\text { Cardiologista, } \\
\text { fisioterapeuta, psicóloga, } \\
\text { nutricionista e enfermeira }\end{array}$ & Tabagistas & $\begin{array}{l}\text { Ajudar os } \\
\text { tabagistas a parar } \\
\text { de fumar }\end{array}$ \\
\hline $\begin{array}{l}\quad \text { Dias temáticos } \\
\text { (Combate ao } \\
\text { Tabagismo e da } \\
\text { Hipertensão) }\end{array}$ & $\begin{array}{l}\text { Ambulatório de } \\
\text { Hipertensão Arterial }\end{array}$ & $\begin{array}{l}\text { Cardiologista, } \\
\text { Fisioterapeuta, } \\
\text { psicóloga, educador } \\
\text { físico, enfermeira, } \\
\text { nutricionista }\end{array}$ & $\begin{array}{l}\text { Comunidade em } \\
\text { geral }\end{array}$ & $\begin{array}{l}\text { Orientações } \\
\text { relacionadas à } \\
\text { prevenção e } \\
\text { tratamento da } \\
\text { hipertensão e } \\
\text { tabagismo }\end{array}$ \\
\hline $\begin{array}{l}\text { Reabilitação } \\
\text { Cardíaca }\end{array}$ & $\begin{array}{l}\text { Serviço de } \\
\text { Fisioterapia }\end{array}$ & $\begin{array}{l}\text { Fisioterapeuta e } \\
\text { educador físico }\end{array}$ & \begin{tabular}{l}
\multicolumn{1}{c}{ Pacientes com } \\
insuficiência \\
cardíaca, \\
coronariopatas, \\
valvopatas, \\
transplantados
\end{tabular} & $\begin{array}{l}\text { Promover a } \\
\text { reabilitação } \\
\text { através do } \\
\text { exercício físico }\end{array}$ \\
\hline Grupo GLPP & $\begin{array}{l}\text { Ambulatório de } \\
\text { Hipertensão Arterial }\end{array}$ & $\begin{array}{l}\text { Enfermagem, } \\
\text { Fisioterapeuta, psicóloga, } \\
\text { nutricionista }\end{array}$ & $\begin{array}{l}\quad \text { Pacientes com } \\
\text { síndrome } \\
\text { metabólica }\end{array}$ & $\begin{array}{l}\quad \text { Controle da } \\
\text { glicemia, lipídios, } \\
\text { peso e pressão }\end{array}$ \\
\hline
\end{tabular}

Fonte: Instituição, 2009 


\section{1) Aula mensal: tratamento da hipertensão arterial}

Realizada por uma equipe multidisciplinar composta por: enfermeira, psicóloga, nutricionista, cardiologista e fisioterapeuta. Esta aula foi oferecida para pacientes que estavam começando a fazer tratamento no hospital, e os acompanhantes também foram convidados a participar, visto que o cuidador tem um importante papel no tratamento do paciente hipertenso. Esta aula durou aproximadamente duas horas, foi realizada em um auditório do hospital, e ficou completamente lotada durante sua realização, com aproximadamente cem pessoas no total. No mês de Julho de 2008, por exemplo, estiveram presentes noventa e seis hipertensos nesta aula.

Os pontos abordados de uma forma geral diziam respeito ao funcionamento do hospital, marcação de consultas, cuidados ao realizar exames e orientações específicas com cada profissional da equipe.

O serviço de enfermagem abordou a parte prática de funcionamento do serviço do hospital, preparação do paciente para exames laboratoriais, importância do uso do cartão de identificação do paciente em cada procedimento realizado no hospital, marcação de consultas e retorno, uso da farmácia do hospital e necessidades eventuais sobre relatório para perícias de ida ao dentista e ao Instituto Nacional do Seguro Social (INSS).

O serviço de Psicologia falou da influência do estresse e ansiedade no controle da pressão arterial, sinais e formas de preveni-lo ou amenizá-lo. A depressão também foi um assunto abordado na palestra.

O serviço de Nutrição, essencial no acompanhamento e controle da pressão arterial do paciente, enfatizou a importância de uma alimentação 
saudável e a profissional indicou alimentos que deviam ser evitados, abolidos e aqueles que poderiam ser ingeridos.

O serviço de Cardiologia conceituou a hipertensão arterial, revelou as estatísticas da doença no Brasil, conseqüências da doença e a importância das mudanças no estilo de vida para um bom controle da cardiopatia. Abordou temas gerais, como alimentação, tratamento medicamentoso e atividade física.

O serviço de Fisioterapia abordou temas referentes à prática de atividade física: benefícios do exercício físico, tipos, recomendações em relação a uso de calçados e roupas adequados, precauções referentes a sintomas sentidos durante a atividade física, importância do alongamento antes e após o exercício. Ao final da palestra, o fisioterapeuta convidou os pacientes para fazerem parte de um programa do ambulatório de hipertensão que promove uma prática supervisionada de atividade física, durante três meses, no hospital.

Como dito anteriormente, esta aula era uma forma de apresentar aos novos pacientes do hospital como era o funcionamento da instituição e tinha o propósito também de promover orientações gerais sobre o tratamento medicamentoso e não-medicamentoso da hipertensão arterial. Conforme observado, a aula era bastante longa e cansativa, com duração aproximada de duas horas e com cinco profissionais diferentes. Uma vez que o auditório ficou completamente lotado, era difícil uma maior integração do profissional com o paciente, podendo até inibir um esclarecimento maior com possíveis dúvidas que poderiam surgir durante a palestra. 
Um programa de educação em saúde eficaz deve levar em consideração o contexto no qual aquele sujeito está inserido, e, acima de tudo, fazer com que haja uma comunicação entre profissional e sujeito, e não apenas uma transmissão de saberes.

O termo "educação em saúde" geralmente é utilizado de forma bastante limitada, focando suas ações de aprendizagem voltadas à mudança de comportamentos individuais (Pelicioni et al.,2008). Para Alves (2005) educar para a saúde significa ir além da assistência curativa, significa priorizar intervenções preventivas e promocionais.

Infelizmente, ainda hoje, os programas de promoção de saúde estão muito focados em mudanças de comportamento e de estilo de vida, no que o paciente pode e no que não pode fazer, e, especialmente quando falamos de doença cardiovascular, são baseados nos fatores de risco: não fumar, não beber, procurar levar uma vida com menos estresse, prática de atividade física, adesão a uma dieta saudável, controle do peso, pressão arterial e colesterol.

O que pudemos perceber nesta aula é que existiam muitas dúvidas entre os pacientes, os profissionais estavam muito preocupados em "passar" a informação correta, mas não havia uma interação maior com os pacientes, nem estímulo ao diálogo, e o foco maior era na doença e não na saúde.

Uma sugestão seria organizar esta palestra com uma duração menor, tornando a atividade menos cansativa e mais estimulante. Grupos menores facilitariam o diálogo e o tira-dúvidas dos pacientes. A palestra deveria abordar além de fatores de risco, outros temas relacionados à saúde de uma 
forma geral, como a importância de um bom relacionamento com a família, sugestões de lazer e atividade ocupacional.

\section{2) Aula quinzenal de pré e pós-operatório de cirurgia cardíaca}

Aula ministrada por residentes de fisioterapia cardiovascular do hospital, e supervisionada por um fisioterapeuta preceptor, efetivo do hospital, destinada a pacientes que fizeram intervenções cirúrgicas (coronariopatas, valvopatas) e acompanhantes, durante o período do pré e pós-operatório destes pacientes internados no hospital.

$\mathrm{Na}$ aula foram abordados quais os principais fatores de risco cardiovascular, definições de coronariopatias e procedimentos realizados na revascularização do miocárdio. $O$ fisioterapeuta deu ênfase aos benefícios dos exercícios físicos, a forma adequada de fazer os exercícios (tipo de roupa apropriada, tipo de calçado, horário), recomendações de atividades que poderiam ser feitas em casa, atividades de lazer e no trabalho e formas de alongamento. Também abordou a importância da reabilitação cardiovascular, seus benefícios e a possibilidade deste tratamento ser feito na própria instituição. Ao final, o fisioterapeuta convidou os pacientes presentes na aula a entrarem no programa de reabilitação cardíaca do hospital. Após o término da aula, o fisioterapeuta entregou quatro folhetos autoexplicativos para os pacientes relacionados à aula.

O primeiro folheto (anexo 02) possuía ilustrações de recomendação e procedimentos que foram feitos antes, durante e após a cirurgia, como por exemplo: não fumar, fazer jejum completo, anestesia, recuperação em UTI e retorno posterior à enfermaria, realização da fisioterapia pós-cirurgia e 
acompanhamento clínico. Continha também os benefícios da reabilitação cardíaca durante a fase hospitalar e pós-alta: melhora da qualidade de vida, redução do estresse, melhora da auto-estima, maior disposição para realização das atividades de vida diária, diminuição ou controle dos fatores de risco, melhora do condicionamento físico e melhora do desempenho sexual.

O segundo folheto (anexo 03) tinha como tema especificamente a caminhada. Recomendava que vinte minutos seria o tempo necessário para promover um aumento no condicionamento físico, com uma freqüência mínima de três a cinco vezes por semana. Falava da importância de começar a realizar os exercícios aos poucos para quem é sedentário. Fazia recomendações a respeito de o paciente ficar atento aos sinais de cansaço extremo e ritmo do coração, recomendava o uso de roupas leves e tênis confortável durante a caminhada, e recomendava a ingesta de líquido antes, durante e depois da caminhada. Por fim, o folheto mostrava ilustrações de alongamentos para membros superiores e inferiores.

O terceiro folheto (anexo 04) mostrava orientações de exercícios para serem feitos em casa. Enfatizava a importância da prática de atividade física nas pessoas com cardiopatias e seus benefícios como aumento da qualidade de vida, sensação de bem-estar e mais disposição para as atividades do dia-a-dia. A bicicleta ergométrica, esteira ou caminhada eram os tipos de exercícios mais recomendados, a duração devia ser de quarenta minutos à uma hora por dia com uma freqüência de pelo menos três vezes por semana. Recomendava também que o paciente devia aprender a checar 
seu pulso e ficar atento à sua freqüência cardíaca ideal. Orientava sobre os principais sintomas a serem observados durante a atividade: dor ou aperto no peito, palpitações, falta de ar, vertigem ou sinal de fraqueza, suor frio, náuseas. Lembrava que o paciente devia estar atento à percepção do esforço durante o exercício através da escala de Borg, na qual a nota 13 (ligeiramente cansativo) é a ideal, e ao final mostrava exercícios de alongamento para membros superiores e inferiores, e alertava para não "prender a respiração" durante os movimentos.

Por fim, foi entregue uma ficha (anexo 05), na qual os pacientes deviam fazer um controle diário de exercícios em casa, anotando a data de realização do exercício, qual a duração da caminhada, qual número na escala de Borg alcançou e qual foi a medida da pressão arterial antes da caminhada. Essa ficha serviria como monitorização da evolução do paciente e devia ser trazida toda vez que o paciente fosse para uma consulta com o fisioterapeuta, tanto no ambulatório de hipertensão ou na própria reabilitação cardíaca.

Esta aula foi realizada em uma sala pequena, próxima da enfermaria na qual estes pacientes estão internados. Durou aproximadamente uma meia hora, e nas duas atividades observadas, o grupo de pacientes era pequeno, em média cinco participaram de cada uma. Esta atividade, realizada especificamente pelos fisioterapeutas, é de grande importância, visto que pacientes que foram submetidos a cirurgias estão bastante frágeis, necessitando de uma atenção maior, e geralmente com muitas dúvidas de 
como será sua recuperação e adaptação e/ou readaptação aos novos hábitos de vida.

Foi observado mais uma vez, que o foco é na doença cardiovascular, e mudanças de estilo de vida. No caso, foi enfatizado a importância da prática de atividade física e estímulo à mesma. Como existia um grupo bem pequeno, era possível perceber que os pacientes se sentiam confortáveis em expor suas dúvidas e questionamentos, o que é bastante desejável em ações de educação em saúde.

A ficha de freqüência, na qual eles deveriam anotar os dias da caminhada, é de extrema importância como um estímulo inicial, porém na ocasião não foi explicado aos pacientes como deveria ser preenchida.

Em entrevista com o chefe do serviço, este nos relatou que muitos pacientes acabavam recebendo alta sem passar por esta aula na enfermaria, pois esta era realizada quinzenalmente, havendo uma necessidade maior de profissionais que pudessem atender os pacientes na enfermaria, e também participar de mais ações como esta, dentro de seu horário de trabalho.

A ressalva que gostaríamos de fazer está relacionada com a entrega de vários folhetos aos pacientes, e que muitas das vezes nem são lidos pelos mesmos. Em outras atividades os folhetos também estavam presentes, o que será apresentado mais adiante.

Sheedy et al (2000) realizaram um estudo que tinha como objetivo desenvolver e testar uma breve intervenção educacional para promover a atividade física entre pacientes de uma clinica de Fisioterapia. A intervenção 
consistia em um breve aconselhamento sobre atividade física (cinco minutos), um livreto com informações reforçando os benefícios dos exercícios e um diário que era entregue aos pacientes no qual eles colocariam objetivos a serem alcançados e o progresso gradativo de duração das caminhadas. Ao serem entrevistados posteriormente, somente $48 \%$ dos pacientes leram o livreto entregue no início da intervenção.

Para Santos (2005), em um trabalho educativo, o folheto é útil, pois reforça mensagens, fornece informações adicionais, auxilia na fixação dos conhecimentos e estimula a adoção de medidas que foram recomendadas. No entanto, o material em si não conduzirá a um comportamento mais saudável, principalmente se apresentar jargões e termos técnicos, ilustrações pobres, longos e complicados textos. Os folhetos das atividades possuíam linguagem clara, acessível, ilustrações simples e explicativas. Porém, não podemos garantir que tenham sido atingidos os objetivos de esclarecimento e informação.

\section{3) Grupos de atividade física (3x /semana)}

Correspondia aos grupos de atividade física do Ambulatório de Hipertensão: eram dois grupos formados por hipertensos que faziam acompanhamento ambulatorial no hospital, e tinha a duração de três meses, com freqüência de três vezes por semana. Cada grupo era formado por uma média de doze pacientes. Os pacientes que se interessavam em participar deste grupo passavam por uma seleção, e de acordo com a demanda eram chamados para fazer parte do grupo. 
Os pacientes eram avaliados na consulta com o fisioterapeuta e cardiologista no ambulatório de Hipertensão, e aqueles com a pressão arterial mais estável participavam do grupo que realizava caminhadas em um parque próximo ao hospital. Aqueles que possuíam a pressão mais difícil de controlar eram encaminhados para o grupo que fazia atividades na quadra esportiva do próprio hospital.

Cada grupo era supervisionado por um fisioterapeuta e eram realizados exercícios aeróbicos e resistidos na quadra do hospital e caminhadas no parque. Aqueles que não podiam participar desses grupos ou estavam esperando vaga para entrar, recebiam orientações individuais relacionadas à prática de exercícios físicos durante a consulta com o fisioterapeuta no ambulatório de Hipertensão. Para os pacientes mais estáveis, a consulta de retorno era marcada para cada seis meses, e para aqueles pacientes mais graves, ou com uma maior dificuldade de adesão ao tratamento nãomedicamentoso, a consulta de retorno era antecipada para cada três meses.

Estes grupos de atividade física, oferecidos aos hipertensos do hospital, são de fundamental importância, servindo como um estímulo inicial para a prática de atividade física, especialmente para aquelas pessoas que foram sedentárias a vida inteira. Da mesma maneira, estes pacientes necessitam além de uma motivação inicial, de uma orientação, um preparo para a correta realização dos exercícios, pois muitos deles são sedentários.

Sabemos que o sedentarismo é uma das principais causas de desenvolvimento de doenças cardiovasculares, e mesmo em pessoas com patologias instaladas, faz-se necessário a prática de exercícios para evitar 
uma progressão e promover uma manutenção da saúde de uma forma geral (Cobb et al.,2006; Zaho et al., 2008). Atividades em grupo possuem o benefício de promover interação, motivação e uma maior sociabilização entre os indivíduos (Song e Lee,2001).

Pacientes que convivem com doenças crônicas necessitam conviver com uma série de adaptações em sua vida, gerando muitas vezes estresse, ansiedade e depressão. Pacientes com doenças cardíacas ou que foram submetidos à cirurgias cardíacas, precisam de um acompanhamento e estímulos necessários para que as mudanças em seu estilo de vida possam vir com naturalidade, e não se tornem um peso a mais em suas vidas, acarretando conseqüências indesejáveis (Sundel et al., 2007).

No caso da hipertensão arterial, uma série de modificações é necessária, adoção de uma dieta saudável, prática de atividade física, controle do estresse e da ansiedade, não fumar, não beber, controle dos medicamentos, e estes pacientes necessitam ser acompanhados com toda atenção.

Condon e McCarhty (2006) chamam a atenção para o fato que pacientes cardiopatas, especialmente os hipertensos, precisam realizar mudanças de uma só vez em seu estilo de vida, o que pode comprometer a adesão destes hábitos a longo prazo. Para uma maior eficácia do tratamento destes grupos, seria interessante incorporar atividades de educação em saúde para um acompanhamento mais completo.

Estes grupos podem servir também como uma rede de apoio. Durante as observações, notou-se que os pacientes gostavam de estar participando 
das atividades, faziam a caminhada e os exercícios com prazer e não como uma obrigação, trocavam idéias, compartilhavam dúvidas, e esse relacionamento entre eles ajuda no decorrer do tratamento e na manutenção de sua saúde. O relacionamento com os profissionais também é um ganho positivo, uma vez que se forma um vínculo com o grupo. O processo de promoção da saúde deve envolver a participação dos indivíduos na tomada de decisões para manutenção de sua saúde, desta forma estas atividades contribuem de forma positiva para o desenvolvimento do autocuidado dos pacientes.

Convém salientar ainda, que o papel do fisioterapeuta além de promover um condicionamento cárdio-respiratório, promove também uma manutenção da saúde de uma forma geral, e o bem estar físico neste caso vem acompanhado também do bem-estar psicológico.

\section{4) Programa Anti-Tabagismo}

O ambulatório de hipertensão arterial da instituição promove anualmente um programa que visa ajudar um grupo de fumantes a pararem com o tabagismo. Cada grupo é formado por trinta pessoas, e o programa tem uma longa fila de espera. Este tratamento tem a duração de um ano, e têm sessões uma vez por semana, num período de seis semanas. As sessões tinham a duração de uma hora, e os participantes recebiam material de apoio referente ao assunto apresentado naquela determinada sessão. Após esses encontros iniciais, foram agendadas sessões de manutenção após quinze, trinta, três meses e um ano. O programa contava com uma 
equipe multidisciplinar, onde estava presente o cardiologista, psicóloga, nutricionista, enfermeira e fisioterapeuta.

Ao final da primeira sessão, os pacientes receberam três folhetos, um em relação à orientação de exercícios, o segundo relacionado aos benefícios de deixar de fumar, dicas de como controlar a ansiedade e o terceiro com orientações para parar de fumar. Em cada sessão um profissional era responsável por abordar um assunto específico de sua área. Na sessão específica da Fisioterapia, foi abordada a temática dos exercícios físicos, seus benefícios psicológicos e físicos, orientações em relação aos cuidados que devem ser tomados ao realizar caminhadas, como por exemplo: uso adequado de calçados e roupas leves, horário adequado, importância de observar sinais de alerta para interromper o exercício e foi entregue um folheto com orientações de exercícios de relaxamento para serem feitos em casa.

O primeiro folheto (anexo 06) continha orientações de exercícios, sua importância e principais benefícios, como prevenção e auxílio no controle da pressão arterial, redução dos níveis de colesterol, diminuição de risco de infarto, e melhora da função cardiopulmonar. Mencionava os sinais de alerta que deviam ser observados (dor/pressão no peito, palpitações, dispnéia, vertigem, suor frio, náuseas) durante o exercício, mostrava como avaliar a percepção de esforço através da escala de Borg e ilustrava os tipos de alongamentos que poderiam ser feitos.

O segundo folheto (anexo 07) apresentava dicas de como parar de fumar. Mostrava que existem diversas formas de parada do tabagismo e que 
cada um deveria escolher a sua: parada abrupta (mais eficaz segundo pesquisas), redução gradual ou adiamento gradual. Estavam presentes ainda, dicas de como evitar o cheiro e objetos associados ao cigarro, troca de roupas, lençóis, retirada de isqueiros e cinzeiros da casa e evitar hábitos que estejam associados ao fumo, como fumar e falar ao telefone, beber e tomar café.

Este folheto também abordava a questão de como o fumante deveria agir diante da chamada "fissura", ou seja, um grande desejo de fumar, uma reação forte que aparece e que deveria ser controlada com medidas simples, como beber água, respirar profundamente, comer frutas ou mascar cravo, gengibre, tentando dessa forma diminuir a ansiedade. Outra medida mencionada era a prática de atividade física, que ajuda na diminuição da ansiedade e controle do peso. As mudanças que ocorrem no corpo ao deixar de fumar são mostradas e o folheto terminava com uma mensagem de motivação para o fumante, para que continuasse tentando, mesmo que ocorresse uma recaída.

O terceiro folheto (anexo 08) apresentava mais orientações para parar de fumar. Apresentava estatísticas de fumantes no Brasil e no mundo, e taxas de mortalidade por doenças associadas ao tabaco. Demonstrava as conseqüências do fumo sobre a saúde, como risco de desenvolver diversos tipos de câncer, doenças broncopulmonares, diminuição dos sentidos como olfato e gustação, risco de infarto do miocárdio, acidente vascular cerebral e agravo da hipertensão arterial. 
O terceiro folheto mostrava ainda as vantagens de cessação do tabagismo e fornecia dicas de alimentação correta, com o objetivo de controle do peso, através de alimentos que deveriam ser consumidos e aqueles que deveriam ser evitados. A importância da realização e os benefícios dos exercícios físicos também foram enfatizados, orientando um plano de execução da atividade física (tipo de exercício, freqüência que devia ser feito, duração, uso de roupas e calçados adequados).

O quarto folheto (anexo 9) foi entregue no programa de exercícios de relaxamento na sessão específica realizada com o fisioterapeuta. $O$ folheto apresentava três exercícios de relaxamento para serem feitos em casa, com o objetivo de diminuir a ansiedade causada pela parada do tabagismo, especialmente nos primeiros dias.

A primeira técnica era um exercício feito basicamente com respirações lentas e profundas, alternando com pausa na respiração e expiração lenta. $\mathrm{O}$ segundo exercício usava o princípio de contração muscular seguida de relaxamento muscular. Dessa formas, recomendava que o indivíduo contraísse desde os pés, tornozelos, panturrilha, coxas, abdômen, tórax, braços, ombros, pescoço, face, boca, olhos e couro cabeludo. Após isso, o indivíduo deveria sentir um relaxamento como um todo do corpo. Na terceira técnica, chamada "exercício fantasia", recomendava-se que o indivíduo realizasse respirações profundas, seguidas de relaxamento, e começasse a ter pensamentos leves, imaginando-se no meio da natureza, tentando se colocar naquele ambiente. Ao final do relaxamento, mentalizasse uma data para parar de fumar. 
O cigarro é responsável por uma série de malefícios à saúde do ser humano, e, programas como este, especialmente oferecidos em um hospital especializado em doenças cardiovasculares é de fundamental importância. Tabagistas que fazem terapias e programas realizados em grupo têm uma chance maior de parar de fumar que aqueles que tentam parar por conta própria (Stead e Lancaster, 2005; Broszkiewicz et al., 2008).

Este programa é baseado nas recomendações do Instituto Nacional do Câncer (INCA) e apresenta uma abordagem congnitivo-comportamental. $\mathrm{O}$ papel do fisioterapeuta está bem definido, este promove a divulgação da importância dos benefícios do exercício físico para quem necessita parar com o cigarro, e também orienta sessões de relaxamento que devem ser feitas em casa.

A atividade física é um aliado importante para indivíduos que desejam parar de fumar, pois auxilia na síndrome de abstinência causada pela ausência da nicotina, e ajuda no manejo com o ganho de peso causado pela cessação do tabagismo (Ussher et al., 2008).

Nesta atividade uma série de folhetos foi entregue, e como foi observado anteriormente, pesquisam mostram que uma pequena porcentagem do grupo realmente lê os folhetos posteriormente. Outro ponto importante em relação à atuação específica do fisioterapeuta, é que o relaxamento deveria ser demonstrado e feito durante a sessão do programa, possibilitando às pessoas se acostumarem com aquele processo de relaxar, essencial para diminuir a ansiedade proporcionada pela abstinência. 


\section{5) Reabilitação Cardíaca}

É um programa que atende pacientes coronariopatas, valvopatas e pacientes com insuficiência cardíaca da instituição. Era realizado três vezes por semana, durante uma hora e durava um período de três meses. A reabilitação do hospital possui duas turmas, cada turma formada por dez pacientes. Aqueles mais graves são atendidos pelos fisioterapeutas e aqueles que estão estáveis clinicamente e mais condicionados fisicamente, são supervisionados pelo educador físico.

No começo da sessão, o fisioterapeuta aferiu a pressão arterial de todos, e a freqüência cardíaca dos pacientes era monitorada durante toda a atividade. Neste programa, as sessões duravam uma hora, e começava com exercícios de alongamento, aquecimento. Posteriormente, eram realizados exercícios resistidos para membros superiores, em postura sentada. Em bipedestação, eram realizados exercícios resistidos para membros inferiores, com o uso de caneleiras e auxílio de barras de apoio. Os exercícios aeróbicos vinham em seguida e eram realizados na bicicleta ergométrica ou em esteira. A escala de Borg de percepção de esforço era avaliada pelo paciente, após aproximadamente vinte minutos de bicicleta, e anotada pelo fisioterapeuta, na ficha individual de cada paciente. Finalizavase a sessão com exercícios de alongamento. Em anexo, estão as fotos de um determinado dia do programa (Anexo 10).

Vários autores já demonstraram os benefícios da reabilitação cardíaca (Lavie e Milani, 1995; Sanderson et al., 2007). Mesmo com toda a comprovação científica, muitos hospitais e clínicas não oferecem este tipo de 
atendimento que deveria ser direito de todo paciente cardiopata. Além dos benefícios físicos, a reabilitação promove a saúde do indivíduo de uma forma geral, enfatizando suas potencialidades e mantendo suas funções.

Resultados no tratamento de fatores de risco em pacientes com doença arterial coronariana no estudo European Action on Secondary and Primary Prevention through Intervention to Reduce Events (EUROASPIRE) demonstraram que a prevenção secundária da doença cardiovascular na prática clínica cotidiana é inadequada: a maioria dos pacientes não é indicada para programas de reabilitação cardíaca e menos que um terço deles entra neste tipo de programa (Wood et al., 2008).

Observamos que, da mesma forma que os pacientes dos grupos de atividade física do ambulatório de hipertensão, este grupo do programa de reabilitação cardíaca se sentia muito à vontade com os fisioterapeutas, podíamos perceber um vínculo entre eles e os profissionais, benéficos à manutenção da saúde através daquela atividade física e do tratamento em si.

Apesar da inegável importância do programa de Reabilitação Cardíaca, nos chamou atenção o fato que não existiam atividades de educação em saúde incorporadas ao programa. Os pacientes deste tipo de atividade necessitam também de mudanças nos seus hábitos de vida, e somente a prática de exercício físico não é suficiente para seu tratamento. Cabe ao fisioterapeuta, como profissional de saúde, proporcionar ao seu paciente um tratamento mais completo. 


\section{6) Dias temáticos (Combate ao Tabagismo e da Hipertensão)}

Duas vezes ao ano, vinculados ao Dia do combate ao Tabagismo e dia Nacional da Hipertensão, a instituição oferece um dia de atividade física. Participam neste evento o fisioterapeuta, o cardiologista, a nutricionista, a enfermeira, psicóloga e educador físico. O fisioterapeuta orienta em relação à prática de exercícios físicos, além de promover caminhadas em um parque próximo.

Nesta atividade específica não foi possível fazer a observação, pois no período de coleta de dados a instituição ainda não havia realizado essa ação no ano. O chefe do serviço de Fisioterapia, em sua entrevista, nos explicou que existiam esses dias temáticos, nos quais os fisioterapeutas da instituição participavam orientando a respeito dos benefícios do exercício físico e aferindo a pressão arterial da população que participava da ação.

Apesar de não ter presenciado a atividade, iniciativas como estas são válidas e aproximam a comunidade, especialmente a carente, dos profissionais de saúde. Da mesma forma, os profissionais podem atuar mais na promoção da saúde.

\section{7) Grupo GLPP}

Este grupo, cujas iniciais correspondem à glicemia, lipídeos, peso e pressão, tinha o objetivo de atender pacientes que estavam em tratamento no ambulatório de hipertensão arterial, e que possuíam a síndrome metabólica, que de acordo com a International Diabetes Federation (IDF), é uma síndrome caracterizada pela prevalência conjunta de diabetes ou pré- 
diabetes, obesidade abdominal, alterações do colesterol e pressão arterial elevada.

Este grupo era composto geralmente por vinte pacientes, e foi assistido por uma equipe multidisciplinar composta por enfermeira, nutricionista, psicóloga e fisioterapeuta. Os pacientes, selecionados pela equipe de enfermagem, foram convidados a participar do grupo, em encontros quinzenais, durante um tempo indeterminado, que dependerá de sua evolução clínica, durante os atendimentos com cada profissional.

Os pacientes inicialmente foram divididos em quatro grupos de cinco pessoas cada, e recebiam orientações de cada profissional, cada um abordava temas específicos de sua profissão. No caso do fisioterapeuta, o debate estava focado na prática de exercícios físicos e exame físico.

Como existia uma subdivisão, então eram formados pequenos grupos que permitiam uma maior interação paciente-profissional, possibilitando uma aproximação maior da realidade de cada um. O que pude observar também durante a sessão do grupo, é que os pacientes se sentiam mais à vontade para tirar dúvidas com os profissionais, para falar abertamente do que os aflige, quais suas dificuldades e entre eles havia interação, contribuindo também para um estímulo a mais para continuar com seu tratamento.

Torres et al (2009) realizaram um estudo que visou comparar a efetividade de estratégias, em grupo e individual, de um programa educativo em diabetes. Os resultados demonstraram que as duas estratégias foram eficazes, porém a educação em grupo apresentou melhores resultados de controle glicêmico que a individual. 
De todas as ações de educação em saúde observadas nesta instituição, esta é a que mais se aproximaria dos pressupostos ideais de uma educação libertadora e transformadora, na medida em que aproxima educador do educando, e, além disso, proporciona um contato com a realidade de cada indivíduo. Desta forma, possíveis dificuldades ou problemas poderiam ser resolvidos especificamente para cada paciente, e não com discursos generalizados, como se todos vivessem da mesma forma e na mesma realidade.

Uma questão interessante é que a maioria das atividades oferecidas está direcionada somente ao paciente hipertenso. Existe no hospital uma diversidade de pacientes atendidos e que necessitariam de atividades de promoção de saúde específicas, como por exemplo, coronariopatas e os pacientes com insuficiência cardíaca.

Um obstáculo encontrado na instituição, relatado pelo chefe do setor de Fisioterapia, é a falta de profissionais diante da grande demanda de pacientes, o que pode comprometer inclusive o funcionamento pleno das atividades existentes. Porém, incluir outros tipos de pacientes nas próprias atividades de educação em saúde seria uma forma de inclusão importante.

Durante as atividades observadas, nas quais existia uma equipe multidisciplinar, pudemos perceber a falta de interdisciplinaridade entre os profissionais. Cada profissional se permitia apenas debater e colocar assuntos dentro de sua área. Essa fragmentação das disciplinas limita o atendimento ao paciente, prejudicando o comprometimento dos profissionais diante da resolução de problemas em saúde. 


\subsection{A visão dos profissionais acerca da promoção da saúde}

Um dos objetivos do fisioterapeuta, segundo o código de ética da Fisioterapia é "promover e manter a saúde do indivíduo e reabilitá-lo". Tradicionalmente o fisioterapeuta está distante da promoção da saúde em sua prática clinica, pois segundo Ceccato et al (1992), na Fisioterapia o profissional parece estar voltado para uma pequena parcela do objeto em saúde: a doença e suas seqüelas.

Muitos profissionais têm dificuldade em definir a promoção da saúde, confundindo com a prevenção, e ainda tem a visão estrita de pensar a saúde como "ausência de doença", ocasionando conseqüências em suas ações com foco na doença e no pensar promoção de saúde como mudanças de estilo de vida e nos fatores de risco.

"Eu acho que atividades de promoção da saúde seriam atividades pra, no nosso caso, controle dos fatores de risco. O que mais a gente atuaria seria no sedentarismo, promovendo atividade física, e é o que mais a gente atua aqui, a gente orienta eles a fazer a caminhada controlada, de pelo menos vinte a trinta minutos, no mínimo três vezes por semana"

"Na parte da Fisioterapia e em outras áreas também, porque ainda vê muita essa parte de medicamento, tratamento, não sei, a indústria farmacêutica ainda é muito forte ainda, vê só a parte do tratamento, não tanto da prevenção" (Fisioterapeuta 1) 
"São atividades de caráter educacional, que você educa o paciente. Diferença entre promoção e educação em saúde? Eu sempre aprendi promoção de saúde" "É interessante, é um campo [promoção da saúde] que tende a crescer, e se crescer é muito bom, porque se você trata o paciente antes dele desenvolver tal doença, você tenta prevenir ali, mesmo que ele desenvolva vai ser mais fácil tratar mais pra frente. [...] Então, se o fisioterapeuta atua desde cedo, é importante a promoção da saúde, educar o paciente, elucidar os fatores, acho que é muito interessante, é muito interessante, pra mim é o futuro, é o futuro"

"Aqui na Reab [Reabilitação Cardíaca] são pacientes que estão há muito tempo, então a gente faz a promoção no dia a dia sabe, ah, a alimentação, a caminhada, eles perguntam, a gente vai respondendo. A parte que a gente faz um pouco educativa é que tem alguns pacientes que estão em acompanhamento, então eles tem retorno de 6 em 6 meses, então a gente orienta, olha tem que caminhar, fala da importância do exercício físico, aí ensina toda a etapa, é praticamente isso. É mais um acompanhamento. No dia a dia a gente já atua [...] Por exemplo, o que a gente mais vê são pacientes transplantados, como ele já passou por "poucas e boas" vamos dizer assim, aquele que é bem consciente, que é bem educado, ele leva muito à risca as coisas, e o que tem que ser feito pra ter um prognóstico melhor, ele tem que seguir o que é orientado a ele" (Fisioterapeuta 2) 
"Então, eu acredito assim, que em promoção de saúde, o ideal era você tá naquela prevenção primária, então, na questão da alimentação, de até questões de cuidado com a higiene, um cuidado com a água. Que às vezes eles pensam assim "se a água tá gelada, a água tá limpa", pelo menos lá no Ceará era assim. Você partir lá da base, da questão da alimentação, dos cuidados pessoais, eu acredito que você já tá promovendo saúde" "Educação em saúde? Não sei, talvez o educar seria você tentar conscientizar a pessoa. Tentar fazer com que, não só você falando, tal e tal,mas na verdade você não tá vendo se a pessoa tá se conscientizando, tá se reeducando, em relação a isso. Talvez a educação em saúde tivesse que ser uma coisa mais repetitiva, não sei. E a promoção é tipo aquelas, talvez aquelas campanhas, aleitamento materno, AIDS, são coisas talvez pontuais, não sei"

"Se você conscientiza a pessoa do problema dela de base, se ela entende que a doença dela veio por uma determinada razão, ela vai tentar eliminar aquela causa da vida dela, como uma alimentação muito gordurosa, ou sedentarismo, ou então uma obesidade, e vai tentar evitar problemas futuros. E se você pegar uma população que talvez tenha fatores de risco, mas que ainda não desenvolveu a doença cardíaca, talvez você consiga eliminar os fatores de risco e diminuir a incidência da patologia" "Em relação à minha experiência eu acredito que a Fisioterapia ainda não está muito voltada para a promoção da saúde. Às vezes até de vez em quando a gente dá um puxão de orelha nos pacientes "como é que vocês 
estão se alimentando?", "gente, olha esse peso", sabe, a gente ainda dá uns puxões, mas podia ser visto isso daí" (Fisioterapeuta 3)

"São as práticas, sejam elas preventivas ou não, que visam orientar o paciente a ter uma qualidade de vida melhor" (Fisioterapeuta 4)

"É você fazer tanto a prevenção, quanto esclarecer a população sobre os fatores de risco da doença, como prevenir as doenças. E mesmo no tratamento, quando a pessoa tá com a doença tratar de forma adequada, acho que isso é promoção da saúde" (Fisioterapeuta 5)

"Eu vejo isso como uma ação, em que os profissionais de saúde se movem para tentar, de certa forma, fazer com que essas pessoas, sejam elas pacientes ou não, pra que elas possam ter um conhecimento do que é necessário pra ser saudável, dentre todos os aspectos [...] atividades que você pode trabalhar tanto com orientação, que eu acho que é um fator muito importante, que é a orientação, a forma verbal de se explicar, pode ser a forma também didática, de demonstrações, de figuras, e também algumas atividades que você pode propor a essa pessoa, dentro da atividade física e mudança de estilo de vida" (Fisioterapeuta 6)

Para Heidmann et al (2006) é necessário reconhecer que a maioria dos profissionais de saúde desconhece o verdadeiro significado da promoção à saúde, confundido conceitos de prevenção e promoção. O enfoque 
comportamental de mudança de estilo de vida é predominante, e o conceito de saúde é sinônimo de ausência de doença.

Outro ponto que foi abordado na entrevista dentro desta temática dizia respeito à importância destas ações de promoção de saúde no cotidiano dos pacientes, e como os fisioterapeutas percebiam como estava o autocuidado dos pacientes, seja devido às ações realizadas no hospital, ou de uma maneira geral.

"É importante, você vê que eles melhoram mesmo, incentiva eles a fazerem as atividades, eles mesmo relatam melhora ,e você vê que com essa ação você consegue até, como eles vão melhorando a parte de capacidade [funcional], até as vezes a dosagem do medicamento [diminui], e chegou a ter caso de tirar paciente da fila de transplante aqui"

[...] Sim, sim, tem retorno. Você vê que tem paciente que traz direitinho aquela ficha que a gente pede pra preencher a freqüência da pressão arterial, da caminhada, o Borg também. Quando acaba a ficha tem paciente que fez em casa, anotado tudo" (Fisioterapeuta 1)

"Eles entram na Internet, fuçam tudo e chegam "olha, eu vi que na troca de válvula tem a metálica, a biológica”. Então, eles estão sabendo sim. Tem uns que menos, mas pra maioria a Internet ajuda bastante, pra pesquisar, ler mesmo, eles tão sabendo muito mais. E também os veículos de comunicação hoje em dia falam bastante sobre doenças”(Fisioterapeuta 2) 
"Acho que eles estão se cuidando mais. Ainda acho que é difícil aqueles que realmente incorporam na rotina, de tornar aquilo um hábito de vida, é difícil ainda, é complicado, mas acho que pelo menos no começo muitos deles tentam" (Fisioterapeuta 4)

"Os próprios pacientes sentem a vontade de buscar, conhecer um pouco mais da doença que eles têm, saber o que eles têm, até mesmo pra eles se controlarem. Então muitos sabem, às vezes você tá atendendo um paciente e muitos deles falam; "ah, eu sei medir a minha pressão", até sabem medir a pressão deles, como eles devem agir com relação à doença deles. Eles vão atrás de pesquisas, muita gente vai na Internet procurar, eles vão atrás" "Dá impressão que depois que eles vêm pra cá, que eles têm um acontecimento na vida deles, um problema, aí eles dão um pouquinho mais de valor, então muitos falam "ah, o que eu fazia antes, não vou mais poder fazer", sabe? Eles tomam bem mais cuidado, às vezes até mais com medo de fazer coisas que eles faziam antes na rotina, e ficam com medo de começar a fazer de novo. Mas é o tal cuidado que eles querem ter, pra não ter de novo aquilo" (Fisioterapeuta 5)

"Se eles estão sabendo mais? Eu acredito que sim, principalmente dependendo da classe econômica que você conversa. Eu acho que isso ainda é algo que a classe econômica influencia por demais, a classe econômica um pouco mais alta com certeza tem um conhecimento muito 
maior, mas acho que assim, comparativo em relação há tempos atrás eu acho que mudou sim"

"Acho que o hospital trabalha com muitas palestras, com muitas orientações, com grupos, que montam pra poder dar orientações. Nós mesmos aqui da Fisioterapia fazemos parte de um grupo que trabalha com palestras, tanto a nível de paciente ambulatorial, como também a nível de paciente hospitalar, enfermarias, tanto pré-operatório quanto pós-operatório, então acredito que os pacientes daqui têm um maior autocuidado sim. A tendência é melhorar mais" (Fisioterapeuta 6)

Em estudo realizado por Lima e Araújo (2005), objetivou-se correlacionar ações de autocuidado desenvolvidas por pacientes que realizaram revascularização do miocárdio $(\mathrm{RM})$ com as variáveis: gênero, idade, ocupação, estado civil e antecedentes familiares para alterações cardiovasculares. Os resultados do estudo demonstraram que em relação ao gênero, as mulheres tendem a ter muito mais cuidado com sua saúde; quanto maior a idade, maior o autocuidado, e aqueles que tinham algum familiar com doença cardiovascular possuíam um menor autocuidado. Sugere-se que uma maior atenção seja oferecida aos mais jovens, aos homens e a participação da família nas atividades de promoção de saúde, pois a família, além de ser um ponto de apoio ao paciente, pode ser vulnerável a ter doenças cardíacas também.

Goldmeier e Castro (2005) realizaram um ensaio clínico randomizado em uma população de 74 pacientes internados em uma UTI cardiológica 
após terem sofrido um primeiro infarto agudo do miocárdio. Eles procuraram avaliar a efetividade na redução de fatores de risco para doença arterial coronariana (DAC) através de uma intervenção de enfermagem: a intervenção (Grupo A) constituiu-se de um programa de ações educativas de enfermagem. O grupo controle (Grupo B) foi tratado convencionalmente, sem a intervenção de enfermagem. Os fatores de risco (FR) analisados e submetidos foram obesidade, hipertensão arterial e tabagismo. Os resultados da pesquisa mostraram que após a intervenção de enfermagem (Grupo A), os pacientes tiveram uma redução no número dos fatores de risco, comparados ao Grupo B $(p<0,014)$. O número de fumantes no grupo A foi significativamente menor $(p<0,003)$ que no grupo $B$, observando-se redução de $85 \%$ e $33,33 \%$, respectivamente. Ou seja, as intervenções de educação em saúde são necessárias e importantes no momento da internação, além de possuir baixo custo e metodologia simples.

Segundo os profissionais, os pacientes procuram muitas informações a respeito de sua patologia na internet. $E$ com os recursos atuais de informação, atualmente a internet é um meio bastante comum de pesquisa por "leigos". Seria interessante a instituição utilizar este interesse dos pacientes na rede, como ferramenta de educação em saúde. Além de proporcionar aulas mais estimulantes, os profissionais indicariam quais endereços eletrônicos são mais confiáveis e qualificados, pois nem toda informação lida na internet é correta. No endereço eletrônico da Sociedade Brasileira de Cardiologia existe uma sessão específica destinada para pacientes. 
Nota-se na fala de alguns profissionais que os termos "pode" e "não pode" está muito presente, e isto em educação em saúde poderia transmitir uma sensação de obrigações ou, de certa forma, afastar o diálogo, como se não houvesse possibilidades de negociações entre paciente e profissional.

"É incrível, eles sabem tudo da doença deles, tudo o que podem fazer e o que não podem. Às vezes não pode, mas eles fazem, mas eles têm interesse em saber. E a gente vê aqui, eles buscam, tem interesse em saber. Eles já vêm sabendo. Alguns não, mas outros sim, se você for ver, muitos sabem" (Fisioterapeuta 3)

"É importante pra deixar ele ciente do que ele pode fazer, do que ele não pode fazer, e das coisas que ele pode fazer, ele continuar fazendo o que ela já fazia antes, nas atividades diárias dele, ele fazer com mais consciência, né? Porque muitos deles às vezes não sabem o que podem ou não fazer, às vezes até quando a gente fala "ah, pode fazer tal coisa", "ah, posso?", eles ainda perguntam se pode. Aí até orientar a nova conduta dele, se pode aumentar o ritmo [na caminhada], quando pode, acho que é importante" (Fisioterapeuta 4)

$\mathrm{Na}$ entrevista outro ponto importante abordado dizia respeito às dificuldades que pacientes relatavam a respeito de mudanças em seu estilo de vida ou de adesão ao tratamento. 
"O que eles falam muito quando tu fala de caminhada é que, não a maioria, mas tem uma porcentagem grande que fala "ah, mas eu trabalhei o dia inteiro andando na rua já, vou andar mais?" Eu escutei isso hoje. Na aula de tabagismo a gente foi perguntar e ouvimos isso: "Mas eu ando de quatro da manhã até sete horas da noite, porque eu trabalho na rua andando, vendendo roupa", aí você tem que dar uma outra alternativa, tipo assim, no caso dessa paciente devia ser utilizado o relaxamento, para acalmá-la" (Fisioterapeuta 1)

"Aqui no hospital, dificuldade financeira, entendeu? Tem gente que fala: "ah, eu quero vir", mas é limitado por causa de ônibus, não sei o que, não tem dinheiro pra pagar"

“De alimentação é um pouco de, falta de educar. Tem gente que fala: "ah, mais é tão difícil", sabe fica botando um monte de empecilho? "Ah, mas não vai dar pra comprar isso, não vai dar pra comprar aquilo". Ah, mas eu acho que, assim, mesmo com uma renda baixa, dá pra fazer uma alimentação mais direcionada, mais adequada, podia diminuir o sal, o óleo, é barato, não é uma coisa cara. Caro é carne” (Fisioterapeuta 2)

"O que eu vejo assim, que os pacientes têm mais dificuldade, pra entrar no grupo da reabilitação, ou é a distância, porque moram muito longe, ou a questão financeira mesmo, que eles olham e falam "vai sair muito caro", "três vezes na semana vai sair muito caro, não dá pra eu ficar vindo sempre”. Eles até tem vontade, mas não tem condições” (Fisioterapeuta 3) 
"Com relação à atividade física, muito deles relatam é falta de tempo: "ah, não tenho tempo de reservar aquele horário e tal". Com relação à dieta eu sei pouco, mas eles reclamam "não vou poder comer nada", "não pode comer nada". Alguns reclamam que alguns alimentos "light" ou "diet" são um pouco caros, tem tudo isso. Mas eu acho que no início, assim, logo depois do pós-operatório eles aderem mais" (Fisioterapeuta 4)

"Eu acho que é mais o costume. É que nem a gente. Às vezes a gente se acostuma com certas alimentações, ou determinado tipo de atividade, com aqueles horários, então, pra sair da rotina se torna um pouco difícil, se você trabalha de tal hora a tal hora, então, tem até um horário pra fazer um exercício, mas aí chega em casa, tá com sono, tá com vontade de fazer outra coisa, aí você acaba não fazendo. Ou então, por outro motivo. Mesmo a alimentação, né, todo mundo gosta de comer comida com muito sal, aí se você vai tirar um pouquinho do sal, lógico que todo mundo vai achar muito ruim, não vai ficar a mesma coisa. Mas é só questão de costume. Eu acho que se a pessoa começar, acho que acaba aderindo" (Fisioterapeuta 5)

A dificuldade de adesão a mudanças em estilo de vida, essencial para pacientes cardíacos, é um desafio para todos os profissionais de saúde que convivem com este tipo de paciente. É necessário dar suporte e investigar quais as necessidades, aspirações e motivos pelos quais essa adesão pode estar sendo dificultada. 
Esta dificuldade de adesão pode culminar com o abandono do tratamento, e este é um fator de preocupação e merece ser investigado. No caso da hipertensão arterial, além das dificuldades inerentes do seguimento médico (dificuldade financeira, reações adversas aos medicamentos, dificuldade de acesso aos serviços de saúde), esta patologia caracteriza-se por ser silenciosa e crônica, o que pode ocasionar um "relaxamento" no tratamento por parte do paciente.

Em um estudo observacional com 120 hipertensos realizado por Medeiros (2006) com o objetivo de estudar a adesão ao tratamento da hipertensão arterial em pacientes acompanhados em Unidade Saúde da Família (USF), mostrou que a adesão às recomendações não medicamentosas foi de apenas $30,8 \%$. O abandono do tabagismo obteve a melhor taxa de adesão (72,8\%), seguido pela dieta hipossódica $(47,5 \%)$, aumento na ingestão de frutas e verduras (36,7\%), atividade física $(20,5 \%)$ e controle do peso (4,6\%). O sucesso da adesão esteve relacionado ao melhor conhecimento sobre a doença e a um bom relacionamento com a equipe de saúde.

Busnello et al (2001) investigaram as características associadas ao abandono do seguimento do tratamento da hipertensão arterial em um ambulatório de Cardiologia. Dos 945 pacientes estudados, $56 \%$ abandonaram o tratamento, e identificaram um grupo de risco para abandono de seguimento: pacientes com menor nível de escolaridade, diagnóstico recente e tabagistas. 
Dois profissionais chamaram a atenção em relação às dificuldades de ida ao hospital e a própria questão física decorrente da patologia cardíaca. Pacientes cardiopatas, especialmente os mais graves, têm uma limitação física decorrente da própria patologia, dificultando sua freqüência aos programas oferecidos e também de certa forma funcionando como uma barreira para um acompanhamento maior por parte do profissional.

"Tem paciente que anda cinco metros e já se cansa. Até ele chegar aqui, ele tem que sair, sei lá, com duas horas de antecedência pra ele poder chegar na hora certa. Ele tem várias limitações, anda, tem que parar, anda,tem que parar. Às vezes vem sozinho, e se passa mal, é alguém que tem que socorrer na rua. Se nós pudéssemos atuar no local dele, não eles vindo até nós, seria uma forma interessante também. Falar com a família, orientar também a família, entendeu, não só o paciente” (Fisioterapeuta 5)

"Na sua grande maioria por não conseguirem ser assíduos. A maioria é assim ou é o lado financeiro, que é a experiência que eu tenho, ou às vezes a própria dificuldade de se movimentar até o local. Aí é a gravidade do paciente, muito grave, muito desconforto, dores abdominais, dificuldade de locomoção. Tanto do lado financeiro, como do lado físico mesmo" (Fisioterapeuta 6)

As visitas domiciliares poderiam ser um grande aliado dos profissionais de saúde deste hospital para obter um maior sucesso no tratamento e promoção da saúde, especialmente com os pacientes mais graves. Como 
vimos, existe uma série de obstáculos que podem dificultar a ida deste paciente ao hospital, e conseqüentemente comprometer o resultado final das atividades de promoção de saúde.

$\mathrm{Na}$ instituição apenas os pacientes transplantados recebem visitas em casa pela equipe de enfermagem e pelas assistentes sociais. Inserir o fisioterapeuta também no cronograma destas visitas para este tipo de paciente, como para outros pacientes igualmente graves, pode amenizar as conseqüências maléficas da falta de atividade física e o profissional pode proporcionar outras orientações que dizem respeito à saúde de uma forma geral.

Vejamos nas falas seguintes a questão da importância da família no sucesso de adesão do tratamento, enfocada por dois profissionais.

"Se você orienta o filho, aí o filho fala: "Olha pai, lembra do que a fisioterapeuta falou". É que nem falam, se uma família inteira entra de dieta, você consegue emagrecer, se você tá de dieta e vai todo mundo comer um monte de coisa, um monte de guloseima, não vai funcionar, ele vai ver aquilo e vai querer comer aquilo" (Fisioterapeuta 3 )

"Eu acho, pelo que eu vejo lá fora, parentes mais próximos, que moram na mesma casa, não sei se pai ou a mãe ou irmão, que às vezes pode pensar de um modo diferente, ou às vezes não colabora com o tratamento, que também o paciente precisa disso, então acho que tem que ter uma 
colaboração tanto assim, do paciente principalmente, quanto da família dele, pra ajudar no tratamento" (Fisioterapeuta 5)

Os antecedentes familiares para doença cardiovascular é um fator de risco não-modificável e bastante considerado na anamnese de um cardiopata. Faz-se necessário, desta forma, além de envolver a família no tratamento do paciente, investigar outros familiares no intuito de fazer um rastreamento de outros possíveis casos dentro do núcleo familiar.

Para Lima et al (2001) cabe aos profissionais de saúde a tarefa de desenvolver programas de educação em saúde que envolvam os familiares, já com o intuito de tentar minimizar os fatores de riscos para cardiopatias, incentivando a família a adoção de hábitos saudáveis juntamente com o paciente, favorecendo a prática do autocuidado e melhorando a qualidade de vida de todo o grupo familiar.

Uma questão que foi investigada na entrevista as percepções que os profissionais tinham sobre os obstáculos para realização de ações de promoção de saúde baseadas em seu cotidiano profissional e quais seriam as soluções possíveis.

"Na parte burocrática nem tanto, porque muito daqui é voltado pra isso, a própria instituição é voltada pra isso. O que poderia ser às vezes é falta de espaço físico, a demanda é muito grande, e a gente não tem um número de profissionais suficientes pra poder dar mais atenção pra todo mundo" "Eu acho que precisaria de mais profissionais, pra gente poder ter, abrir mais grupos, ter mais dois grupos na semana. Você vê, por exemplo, o GLPP. 
Deveria ter um grupo a cada 30 dias. No momento a gente atende um grupo, aí depois de 15 dias eles retornam, então a gente tem que dar um tempo, pra ver se já tem condições de dar alta, e só então começar outro grupo" (Fisioterapeuta 1)

"Por exemplo, tem muita gente que vem de longe, faz uma palestra, não sei, eu penso mais ou menos assim, ter um coffe break pros pacientes, ou sei lá, incentivar eles de alguma forma. Incentivar, não sei de que forma. Por que $o$ ser humano é assim,né, eu vou lá porque eu vou ganhar isso, incentivar de alguma forma. Tem muitos [pacientes] que falam: "ah, eu vou lá, escutar a mesma coisa", sabe, tentar modificar, tentar inovar, entendeu?" (Fisioterapeuta 2)

"Talvez fosse interessante, porque só foca o grupo da hipertensão na questão dos fatores de risco, e no grupo da reabilitação, que é um paciente que já ta lá dentro, seria até interessante, separar uma vez a cada 15 dias, já que eles já vem [pro hospital fazer a reabilitação], fazer uma palestra, tipo tira-dúvidas. Poderia abranger mais pacientes" (Fisioterapeuta 3)

"Às vezes a gente vai chamar um paciente pra aula, e ele tá no banho, tá na consulta, paciente tá no raio- $X$, no exame, no soro. Então é mais a rotina do hospital. Alguns deles parecem ter receio de fazer exercício" (Fisioterapeuta 4) 
Olivi e Oliveira (2002) realizaram um estudo com o objetivo de avaliar a dimensão educadora do enfermeiro que atua em unidade hospitalar e analisar sua capacitação para o exercício de educar. Após entrevistar 18 enfermeiros, estes relataram como obstáculos para a atividade de educação em saúde: número de pacientes; complexidade das patologias; muita atividade administrativa; limitações do paciente; exercício de atividades no período noturno; falta de trabalho em equipe; falta de tempo e a filosofia do serviço.

No caso desta pesquisa, os obstáculos seriam a rotina do atendimento, muitas vezes prejudicando o desenvolvimento de atividades paralelas ao atendimento fisioterápico tradicional, a grande demanda, falta de tempo e falta de valorização por parte de outros profissionais do hospital.

Dois profissionais comentaram a respeito de falta de reconhecimento e valorização destas ações de promoção de saúde. O primeiro relatou que alguns pacientes até acham que o profissional não está trabalhando naquele momento da palestra e das orientações. O segundo profissional comentou a respeito da visão que outros profissionais de saúde do hospital têm acerca das ações. Infelizmente ainda constatamos muito, especialmente em um ambiente hospitalar, a valorização do tratamento e reabilitação, em detrimento à promoção da saúde.

"E às vezes, assim, como é muita coisa assim de palestra, orientação, eles acham que você [o profissional] não tá tratando, você tá enrolando. Você sente um pouco disso ainda" (Fisioterapeuta 1) 
"Olha, eu acho que um dos principais obstáculos seria o próprio reconhecimento de todos os profissionais do hospital, eu acredito, dessa necessidade de ações de promoção de saúde. Porque assim, muitas vezes, o próprio profissional, não o que dá a palestra, o próprio profissional em geral, de saúde, ele mesmo não confia e acredita que isso dá certo [...] Então, reconhecer, valorizar a promoção da saúde, pelos profissionais mesmo, acho que é isso. Porque isso acontecendo, aí vem investimento" (Fisioterapeuta 6)

\subsection{As ações de promoção de saúde e o autocuidado dos pacientes: convivendo com uma doença crônica}

Na página seguinte, no quadro 2, segue a apresentação dos pacientes entrevistados, com dados pessoais como sexo, idade, profissão, patologias e/ou tratamento que realizou no hospital no momento da entrevista e quais ações participa e/ou participou na instituição. 
Quadro 2: Apresentação dos pacientes entrevistados:

\begin{tabular}{|c|c|c|c|c|c|}
\hline Entrevistado & Sexo & Idade & Profissão & $\begin{array}{l}\text { Patologia e/ou } \\
\text { tratamento }\end{array}$ & $\begin{array}{l}\quad \text { Ações } \\
\text { que } \\
\text { participa } \\
\text { ou } \\
\text { participou }\end{array}$ \\
\hline Paciente 1 & Masculino & $\begin{array}{r}52 \\
\text { anos } \\
\end{array}$ & Cinegrafista & $\begin{array}{l}\text { Revascularização } \\
\text { do miocárdio }\end{array}$ & $\begin{array}{l}\text { Aula do } \\
\text { pós- } \\
\text { operatório }\end{array}$ \\
\hline Paciente 2 & Masculino & $\begin{array}{r}36 \\
\text { anos } \\
\end{array}$ & Balconista & Valvoplastia & $\begin{array}{l}\text { Aula do } \\
\text { pós- } \\
\text { operatório }\end{array}$ \\
\hline Paciente 3 & Feminino & $\begin{array}{r}58 \\
\text { anos }\end{array}$ & Psicóloga & Troca valvar & $\begin{array}{l}\text { Aula do } \\
\text { pós- } \\
\text { operatório }\end{array}$ \\
\hline Paciente 4 & Feminino & $\begin{array}{r}54 \\
\text { anos } \\
\end{array}$ & $\begin{array}{l}\text { Dona de } \\
\text { casa }\end{array}$ & $\begin{array}{l}\quad \text { Hipertensão, } \\
\text { Diabetes } \\
\text { Obesidade }\end{array}$ & $\begin{array}{l}\text { Grupo } \\
\text { GLPP }\end{array}$ \\
\hline Paciente 5 & Masculino & $\begin{array}{r}63 \\
\text { anos }\end{array}$ & Aposentado & $\begin{array}{l}\quad \text { Hipertensão } \\
\text { Diabetes } \\
\text { sobrepeso }\end{array}$ & $\begin{array}{l}\text { Grupo } \\
\text { GLPP }\end{array}$ \\
\hline Paciente 6 & Masculino & $\begin{array}{r}68 \\
\text { anos }\end{array}$ & Aposentado & \begin{tabular}{l}
\multicolumn{2}{c}{ Hipertensão, } \\
Diabetes e \\
hipercolesterolemia
\end{tabular} & $\begin{array}{l}\text { Grupo } \\
\text { GLPP }\end{array}$ \\
\hline Paciente 7 & Feminino & $\begin{array}{r}57 \\
\text { anos }\end{array}$ & $\begin{array}{l}\text { Dona de } \\
\text { casa }\end{array}$ & $\begin{array}{l}\text { Hipertensão } \\
\text { diabetes }\end{array}$ & $\begin{array}{l}\text { Grupo } \\
\text { GLPP }\end{array}$ \\
\hline
\end{tabular}

Fonte: Instituição,2009

Quando ações e/ou atividades de promoção de saúde são realizadas, um dos objetivos principais deve ser o desenvolvimento da autonomia e habilidades pessoais com a participação das pessoas na construção desse processo (Santos et al., 2006).

Em pacientes com doenças crônicas, como doenças cardiovasculares e diabetes, onde existe uma necessidade de conviver com diversas adaptações na vida diária, o autocuidado deve ser estimulado, proporcionando um aumento da qualidade de vida.

Podemos perceber pelas falas que se seguem que os pacientes relatam sim, uma melhora em seu conhecimento de como viver com as novas adaptações que devem ser incorporadas em seu dia a dia. 
"O que eu aprendi? Bom, de um modo geral, que a gente pode melhorar a nossa vida evitando muitas coisas. Eu não tenho esse problema, graças a Deus, mas cigarro, bebida, atrapalha muito. Nunca fumei, nunca bebi [...] Não aprender, mas voltar a rever o que é bom, o que não é, o que pode ser feito, procurar fazer um exercício específico, pensando nisso .Que nem a fisioterapeuta falou, com roupas adequadas, sapato, um local adequado. Perto da minha casa tem bastante lugar. Não é uma praça, mas tem uma rodovia bem reta que dá pra andar. É mais alimentação que eu vou ter que me reeducar" (Paciente 2)

"Muita coisa eu já sabia. Acrescentou porque eu me senti mais segura pra fazer as coisas. [...] Agora eu tenho uma bagagem bem maior. Se eu não tivesse, eu ia continuar carregando peso, e agora eu sei que eu não posso pegar peso, que hoje eu aprendi lá [na aula do pós-operatório]. Eu vou ter mais cuidado. E é bom pra não ir com tudo. E agora não, eu vi que eu tenho que respeitar o limite do meu corpo" (Paciente 3)

"Acrescentou, porque a gente tá tomando conhecimento do que pode e do que não pode fazer. [...] Na parte de alimentação, na parte de medicamento, na parte de orientação de caminhada, essas coisas tudo ajuda, né?" (Paciente 5) 
"A gente vai observando as palestras, as conversas assim, e é vivendo que a gente vai aprendendo "(Paciente 6)

"Ah, aprendi muito, a gente aprende muito. Aprendi a controlar a pressão aqui, aprendi a comer, quando eu vou comer uma coisa que tem gordura eu penso no que os médicos falam, e tiro a gordura. Aprendi que a caminhada faz muito bem, e realmente eu me sinto muito bem, quando eu saio pra caminhar, três vezes por semana é sagrado" (Paciente 7)

Em torno das doenças cardiovasculares existem diversos mitos e verdades, e através de um maior esclarecimento para a população, podemos fazer com que esta esteja capaz de identificar limites e possibilidades inerentes à sua saúde. A ansiedade é um fator importante que deve ser controlado e minimizado o máximo possível nestas pessoas. A fala da paciente 4 nos mostra o quanto a informação correta e precisa é capaz de proporcionar um maior bem estar nos pacientes:

"Antigamente eu ficava nervosa por qualquer coisa, e agora não. Pelas palestras, pelo menos pra mim, me acalmou muito mais [...] Pelo diabetes, eu não sabia nada. Nos diabetes eu não sabia de nada. Passava no médico, às vezes, um explicava uma coisa, outro explicava outra, e a gente nunca tinha uma coisa certa. Agora não. Aqui com elas, elas explicam direitinho. Antigamente eu não sabia o que comer, pra mim, tudo que eu comia era lucro, não tava nem aí, eu não sabia. Mas agora não, eu já tô sabendo, 
como que eu me trato, como eu tomo os remédios, os, sintomas de muita coisa que eu sentia eu não sabia explicar, agora eu sei, eu tô vivendo melhor com as explicações que eu tive,né?" (Paciente 4)

Outro ponto importante e que fez parte da entrevista dizia respeito aos hábitos ao longo da vida destes pacientes, relacionados aos fatores de risco cardiovascular. Para a maioria, a mudança para hábitos mais saudáveis só aconteceu realmente após tomar conhecimento de sua patologia, tornandose muito mais difícil uma adaptação.

"Nunca fiz dieta, sempre comia o que tinha na frente. Gostava muito de gordura, gostava não, gosto. Bife, costela, o que tiver gordura eu preferia. E exercícios, não fazia. Não fazia exercício não. Que nem hoje na palestra, ter aquela rotina de levantar, fazer alongamento. O que eu fazia era meu dia a dia bem agitado mesmo. Eu levantava, ando bastante pra chegar na primeira condução, de onde eu moro, depois pra voltar a mesma coisa, no serviço é corrido, então o exercício era esse" (Paciente 2)

"A ginástica deve fazer um ano e seis meses que eu faço. Antes eu não fazia nada. Fazia uma caminhadinha aqui, outra ali, mas não levava a sério. E a dieta, foi desde quando começou essa diabetes, que eu comecei aqui [o tratamento], foi que eu fiquei sabendo o que era um diabetes, eu não sabia. Já tem uns três pra quatro anos. Graças a Deus não fumo, não bebo" (Paciente 4) 
"Não bebo, não fumo, e faço tudo que tem que fazer. Regime de alimentação, eu faço há tempos, já, por causa do diabetes, tem que fazer, mas tô fazendo caminhada, uma vez ou outra, tô melhorando sim. Hoje eu não faço extravagância, levo uma vida mais moderada, levo a vida mais tranqüila" (Paciente 5)

“Já faz uns dezenove anos que eu não fumo. Eu parei de fumar porque com esses problemas aqui, é melhor parar de fumar de uma vez, aí deixei de fumar mesmo. Deixei de fumar, deixei de beber pinga porque não vou beber mais, não adianta Na firma lá que eu trabalhava, tinha os médicos. Um dia eu cheguei lá, o cardiologista disse pra mim assim: "o senhor sabe que tem problema de pressão alta", aí eu disse: "saber eu sei, porque eu vivo tomando comprimido que dizem que é pra controlar a pressão". Aí eu larguei mesmo, larguei de fumar, de beber a pinga, pra acabar com a vida de vez, é melhor deixar pra lá. O cara gosta de fazer as coisas dele, e não pode fazer, então larga de uma vez mesmo, já que é tão prejudicial, larga de uma vez. Ou já morre, ou fica bom de uma vez" (Paciente 6)

Em um estudo qualitativo realizado por Condon e McCarthy (2006) foram investigadas quais as perspectivas dos pacientes ao fazer mudanças em seu estilo de vida. Os pesquisadores entrevistaram 10 pacientes que sofreram infarto agudo do miocárdio após seis semanas de alta hospitalar. Os pacientes apresentavam como dificuldade a implementação de diversas mudanças ao mesmo tempo em seu estilo de vida, ocasionando um aumento do estresse, bem como a falta de suporte profissional no manejo de 
seu tratamento. Curiosamente, a maioria dos pacientes relatou frustração, incômodo e irritação com os excessos de proteção por parte da família.

A adoção de hábitos saudáveis somente após a ocorrência de um evento cardíaco (como infarto), ou a descoberta de uma doença crônica (como diabetes), torna esta adaptação mais complexa e dificultosa.

A paciente 3 , submetida a uma troca de válvula devido a uma febre reumática que a acometeu na infância, contou que sempre se cuidou a vida inteira, procurou ter uma alimentação saudável, sempre se manteve ativa, praticando sua atividade física. Curiosamente, de todos os pacientes entrevistados, ela é a única com formação superior e parece ter uma vida economicamente melhor.

"Eu tenho o meu hábito alimentar, não ultrapasso ele. Faz dezesseis anos que eu mantenho o mesmo peso. Eu evito gordura. Faço bastante caminhada, busco alimentos naturais, tudo que é alimento saudável. Nunca fumei, nunca bebi, não tenho vício nenhum. Eu sempre tive hábitos saudáveis" (Paciente 3)

As políticas de promoção de saúde, especialmente quando focamos na medicina cardiovascular, devem estar presentes durante toda a vida de uma pessoa, começando com as crianças, desde o começo da vida, direcionando a participação da população na tomada de decisões em direção a um viver mais saudável, com aumento da qualidade de vida.

O paciente 1 estava internado no hospital há uma semana, e foi submetido pela segunda vez à uma cirurgia de revascularização do 
miocárdio. Ele relata que a primeira cirurgia foi realizada há dezessete anos, e que logo após a alta hospitalar seguia o tratamento de forma rigorosa, e que aos poucos voltou aos maus hábitos alimentares e ao descuido com a saúde.

"No começo você segue à risca. Aí num dia você pega um salame, aí no outro dia você pega duas fatias, aí você avacalha tudo, foi o que eu fiz. É que nem o médico falou na época: "olha, de vez em quando você pode comer". E aí eu de vez em quando comecei a ter que viver de vez em sempre! Fazia nove anos que eu não freqüentava o médico, então eu avacalhei mesmo. Mas durante nove anos, eu tomei a medicação. Não parei nenhum dia. Durante nove anos eu não fui ao médico, acho que se tivesse ido como no começo, eu não estaria aqui hoje. Começou naquela: "semana que vem eu marco, semana que vem eu marco", aí se passou nove anos. $A$ única coisa que eu fiz de bom mesmo, foi que eu deixei de fumar. Faz dezessete anos que eu não fumo" (Paciente 1)

Já foi comprovada a importância de um acompanhamento dos pacientes que foram submetidos a cirurgias cardíacas, como por exemplo, a revascularização do miocárdio. Alguns maus hábitos de vida podem retornar ou permanecer após a cirurgia, ocasionando mau prognóstico e podendo acarretar na necessidade de uma nova cirurgia (Pinheiro et al., 2007).

Um estudo clínico randomizado realizado por Strömberg et al (2003) tinha o objetivo de fazer um acompanhamento de pacientes com insuficiência cardíaca até um ano pós alta hospitalar. As variáveis avaliadas 
eram mortalidade, morbidade e autocuidado dos pacientes. Durante um ano, a equipe de enfermagem realizou visitas periódicas, e nestas visitas os profissionais avaliavam a condição clínica decorrente da insuficiência cardíaca, o tratamento em si, orientavam sobre o manejo da patologia através de educação em saúde e davam suporte social ao paciente e à família.

Os resultados deste estudo mostraram que neste grupo que recebeu visitas, houve uma diminuição de 55\% em admissões e idas ao hospital, e o autocuidado dos pacientes era três vezes maior em relação ao grupocontrole. Isto demonstra que o acompanhamento destes pacientes pós alta é imprescindível, e pode melhorar a sobrevivência e o autocuidado, bem como diminuir o número de eventos negativos, readmissões e custos aos serviços de saúde.

O relacionamento entre os profissionais de saúde e os pacientes é um fator importante para aumentar a eficácia de ações de promoção e educação em saúde, pois permite a abertura do diálogo e cria oportunidades de troca de saberes. O profissional que escuta seu paciente consegue se aproximar da realidade na qual ele está inserido, desta forma criando oportunidades de reais mudanças e sucesso em seu tratamento.

Um ponto focado na entrevista era a linguagem usada pelos profissionais e quão acessíveis estes eram na ótica dos pacientes. As falas expressam que os pacientes estavam bem satisfeitos com os profissionais e, em relação a esta temática, não relataram nenhum conflito. 
"Ah, eles falam com a gente de uma maneira bem clara.Até conversei com meu amigo aqui de quarto, que eu já passei por outros hospitais. É aquele negócio deles conversarem entre eles, numa linguagem que a gente não entende, então a gente fica meio..tem palavras que eles falam que a gente pensa: "poxa vida, o que é isso? Deve ser grave". Aqui não, a gente não teve esse problema. Conversam normal, falam o que é pra falar: "você tem a válvula ruim, colocamos a válvula de porco, um tecido". Foi bem claro mesmo. A explicação deles não deixou dúvida nenhuma. E a aula também, foi muito boa. Apesar de ser muito rápida, né, foi muito boa" (Paciente 2)

"Ah, nessa parte eu dou sorte. Os médicos me explicam muito bem. Todos. Só não entra mais, porque eu sou uma cabeça muito dura. Mas eles explicam muito bem as coisas" (Paciente 4)

"Não, pra mim tá tudo bom, não tenho do que reclamar não. Pra mim o que eles falam, pra mim tá bom" (Paciente 6)

Em duas pacientes foram observadas co-morbidades que dificultavam a prática da atividade física. A paciente 4 relatou que, apesar das dores piorarem depois da ginástica, ela continuava a fazer. Durante o atendimento que acompanhei o profissional não apresentou alternativas a ela, e ao final da entrevista, sugeri que ela procurasse fazer uma atividade de baixo impacto nas articulações e se adequaria melhor às suas limitações: a hidroginástica. 
"Eu tenho osteoporose, artrite, artrose, bursite, tendinite. Tenho no joelho, nos dois joelhos, tenho osteoporose no calcanhar, e quando eu movimento um pouquinho mais, em vez de melhorar, faz é doer mais. Aí é o que eu faço por dia, três vezes por semana que eu vou e faço a ginástica. Ah, eu gosto, só que me prejudica muito, porque eu tenho problema nos ossos, me prejudica muito. Depois eu sinto dor. Nossa, eu fico imprestável, sem poder andar, sem poder levantar os braços, fico parecendo um robô" (Paciente 4)

"Fazia hidroginástica. Não faço mais porque eu tive um problema muito feio na perna, é por isso que eu to indo pra lá [após a entrevista, a paciente ia para uma consulta com um ortopedista]. Tô aguardando há três meses esta consulta. Ficou toda preta a minha perna, e os meus dedos estão pro lado. Apesar do meu pé tá desse jeito, eu continuo minha caminhada. Mas isso é agora. De uns três meses pra cá os dedos estão se entortando" (Paciente 7) A prática de atividade física é um importante componente no tratamento de doenças cardíacas. A artrite e outras doenças ortopédicas são comorbidades comuns entre cardiopatas, e a dor nas articulações, aliada ao medo de piora no dano articular, pode ser pouco reconhecido pelos profissionais como uma barreira para a prática de atividade física nestes pacientes (Centers for Disease Control and Prevention, 2009).

Com o avançar da idade, surgem alterações fisiológicas inerentes ao envelhecimento. Ter uma vida com qualidade é o principal objetivo do envelhecimento saudável (Lebrão e Laurenti, 2005; Mota e Aguiar, 2007). 
Infelizmente nem sempre as pessoas se preocupam em preservar a saúde, facilitando o surgimento das doenças crônicas e alterações patológicas na velhice.

Um paciente com doença cardíaca, em sua grande maioria, possui uma idade avançada, podendo apresentar vários co-morbidades. O que vemos muito na prática clínica são obstáculos à prática de atividade física: pacientes com problemas ortopédicos, posturais e de equilíbrio. Como profissionais de saúde, nosso olhar deve ser direcionado de uma forma holística, proporcionando alternativas inerentes a cada sujeito, desta forma restabelecendo sua saúde. É importante que estejamos atentos ao todo.

Dentre as entrevistas com os fisioterapeutas, somente um enfatizou esta questão de enxergar o paciente de forma integral:

"Se ele tem uma osteoartrose, já é hipertenso, tem um monte de fator de risco, é obeso e tem uma osteoartrose, então além dele ter que perder peso por causa da parte cardiovascular, tem que perder peso por causa da parte ortopédica, entendeu? É um todo. Tratar não só uma parte, aqui tem muita gente que fala assim: "a gente vai reabilitar só a parte cardiovascular". Um bom fisioterapeuta não quer que um paciente infartado desenvolva alterações posturais, que pode vir a prejudicar a minha reabilitação no futuro, entendeu? Apesar da gente ser da parte cardiovascular, mas a gente tem uma formação pra isso. Então será se a gente não der uma atenção maior [pro paciente com osteoartose], "olha o senhor vai ficar no cantinho, vamos trabalhar mais os músculos que estão enfraquecidos e tudo, depois o 
senhor entra no grupo", então, você tá reabilitando a pessoa da mesma forma. E às vezes inserir ela nunca coisa que ela não conseguia fazer e melhorando as duas coisas ao mesmo tempo [parte cardiovascular e ortopédica]" (Fisioterapeuta 2)

Ao final da entrevista, quando indagados sobre interesses em saber algum tema sobre saúde, e dúvidas de uma forma geral, os pacientes eram enfáticos em demonstrar interesse somente sobre sua patologia e/ou tratamento.

"De momento assim, nada. O que eu vou questionar assim com o médico é o que eu vou poder fazer realmente, né, relacionada à minha cirurgia, o que pode me prejudicar, porque ainda não sei assim, com certeza até que ponto eu posso fazer um esforço. Por enquanto a minha dúvida é só essa. Eu quero tirar dúvidas com o médico, é mais isso daí" (Paciente 2)

"Acho que nada, porque da minha parte, a parte que eu preciso, eu tô sabendo" (Paciente 4)

"Não, porque a gente cuida do que tem, e não se preocupa com o restante, né? Eu tenho diabetes, pressão alta, problema gástrico, então a gente cuida dessas três partes, são as principais pra gente, as que mais interessam. $E$ não tenho nenhuma informação pra saber de outro campo" (Paciente 5)

Este comportamento poderia ser interpretado como uma conseqüência das próprias atividades estarem focadas em patologias específicas e fatores 
de risco. Cabe ao serviço de saúde e aos profissionais procurarem aumentar o escopo das atividades e ações, promoverem a saúde de uma forma plena, e trazerem estes pacientes para uma realidade estabelecida no alcance da saúde em sua forma plena e em ações positivas em busca de qualidade de vida.

Um dos objetivos desta pesquisa era propor um protocolo de ações de promoção da saúde em Cardiologia, baseado nos resultados do estudo.

A seguir, a tabela 1 mostra o resumo do protocolo: 
Tabela 1: Sugestão de Protocolo de ações de promoção de saúde em Cardiologia

\section{Ações de Promoção de Saúde em Cardiologia}

- Formação de grupos pequenos nas aulas de educação em saúde

- Palestras com menor duração

- Atividade somente com tira-dúvidas com pacientes e sugestão de temas de palestras ou encontros pelos próprios pacientes

- Promoção do envolvimento da família nas atividades

- Atividades de educação em saúde para outros pacientes da instituição, e não somente para os hipertensos

- Visitas domiciliares ou acompanhamento via telefone

- Acompanhamento de pacientes internados que não podem eventualmente participar de atividades oferecidas no hospital

- Uso da Internet como instrumento de promoção de saúde 


\section{CONCLUSÕES}

O fisioterapeuta é um profissional extremamente importante no tratamento de pacientes com doenças cardiovasculares, e seu potencial como promotor de saúde ainda está sendo pouco explorado.

Destaca-se na instituição a presença do fisioterapeuta em atividades além da tradicional reabilitação, exercendo seu papel como promotor de saúde, e desta forma, ampliando as possibilidades de oferecer um atendimento mais integral e completo.

Identificamos sete atividades de promoção de saúde oferecidas pela instituição pesquisada, nas quais o fisioterapeuta está inserido e tem seu papel bem definido.

Apesar de ser inegável a importância das atividades, podemos observar que os profissionais procuram enfatizar bastante somente na mudança de estilos de vida e comportamento, muitas vezes reduzindo o foco destas atividades a fatores de risco cardiovascular. As atividades relacionadas à prática de atividade física supervisionada e realizadas em grupo proporcionam uma motivação inicial, especialmente para pacientes sedentários, e possuem o benefício de promover interação, motivação e uma maior sociabilização entre os eles.

Muitos profissionais têm dificuldade em definir a promoção da saúde, confundindo com a prevenção, e ainda tem a visão estrita de pensar a saúde como "ausência de doença", ocasionando conseqüências em suas ações 
com foco na doença e no pensar promoção de saúde como mudanças de estilo de vida e nos fatores de risco.

Um outro ponto que foi observado dizia respeito à importância destas ações de promoção de saúde no cotidiano dos pacientes, e como os fisioterapeutas percebiam como estava o autocuidado dos pacientes, devido às ações realizadas no hospital e de uma maneira geral. E segundo a percepção dos profissionais, existe um maior autocuidado por parte dos pacientes, eles são interessados e procuram saber a respeito de sua doença, através da Internet, televisão, e mesmo com perguntas no dia a dia do tratamento.

A Internet poderia funcionar como uma ferramenta eficaz nas atividades de educação em saúde da instituição, proporcionando aulas e/ou palestras mais estimulantes e os profissionais indicariam endereços eletrônicos mais confiáveis como fonte de busca de conhecimento para os pacientes.

Em relação às dificuldades que os pacientes relatavam a respeito de mudanças em seu estilo de vida ou de adesão ao tratamento, a falta de tempo aparecia como um empecilho à prática de atividade física. Um outro fator dizia respeito à dificuldade financeira que pacientes relatavam para comparecer a atividades promovidas pelo hospital e a distância entre a casa de alguns pacientes e o hospital dificultava a presença em algumas atividades. Em relação à alimentação, profissionais disseram que existiam reclamações por parte de alguns pacientes que alguns alimentos "light" ou "diet" eram caros. 
Foi observado nas falas de alguns profissionais as alterações físicas decorrentes da patologia cardíaca como fatores limitantes às dificuldades de ida ao hospital, funcionando como uma barreira para um acompanhamento maior por parte do profissional. Neste caso, o ideal seria a realização de visitas domiciliares a estes pacientes mais graves, proporcionando um acompanhamento mais próximo deste paciente e melhora no prognóstico.

A importância da participação da família no sucesso de adesão de tratamento é uma questão que também foi discutida nas entrevistas, e mostra que é a presença de um familiar mais próximo durante algumas atividades poderia otimizar e multiplicar o benefício das ações.

Os obstáculos para a realização das atividades de promoção de saúde na instituição destacados pelos fisioterapeutas foram a falta de espaço físico do hospital, a falta de profissionais para a grande demanda de pacientes e a própria rotina de internamento dos pacientes, que muitas vezes dificulta a participação em algumas atividades.

Dois profissionais comentaram a respeito de falta de reconhecimento e valorização destas ações de promoção de saúde. O primeiro relatou que alguns pacientes até acham que o profissional não está trabalhando naquele momento da palestra e das orientações. O segundo profissional comentou a respeito da visão que outros profissionais de saúde têm acerca das ações. Infelizmente, ainda constatamos muito, especialmente em um ambiente hospitalar, a valorização do tratamento e reabilitação, em detrimento à promoção da saúde. 
Observamos que após a participação das atividades de promoção de saúde no hospital, os pacientes relataram uma melhora em seu conhecimento de como viver com as novas adaptações que devem ser incorporadas em seu dia a dia. Os pacientes relataram melhora no controle da pressão arterial, nos cuidados com a alimentação e ao realizar as caminhadas diárias. Os pacientes internados que foram submetidos a cirurgia cardíaca tiraram dúvidas quanto ao tipo de atividade física a ser realizada, o que deveria ser evitado nas tarefas do dia-a-dia, e principalmente, foram orientados a respeitar os limites do próprio corpo.

Alguns pacientes apontaram a importância da informação correta na diminuição da ansiedade e aumento do bem-estar, pois muitas vezes por não entender os sinais e sintomas de sua patologia, se sentiam nervosos e apreensivos por não saber o que estava acontecendo consigo.

Para a maioria dos pacientes, a aquisição de hábitos saudáveis só existiu após saberem que possuía uma patologia cardíaca, o que torna a adaptação na dieta e atividade física mais difícil. É necessário um acompanhamento de pacientes que foram submetidos à cirurgia, pois após um tempo depois da cirurgia, à volta a maus hábitos de vida podem comprometer o prognóstico e até mesmo causar necessidades de uma nova intervenção cirúrgica.

Um ponto investigado na entrevista estava relacionado à linguagem utilizada pelos profissionais, e, segundo os pacientes, é acessível e clara, facilitando e estimulando o diálogo e o entendimento entre pacientes e profissionais. 
Geralmente pacientes cardíacos têm uma idade mais avançada, facilitando a presença de co-morbidades. E na entrevista com pacientes alguns relatam problemas ortopédicos que dificultavam a prática da caminhada.

Nossa investigação foi relevante para vivenciarmos que pacientes cardíacos possuem múltiplas e complexas necessidades, fazendo com que uma equipe bem estruturada, integrada, possa proporcionar um atendimento completo. Da mesma forma, é imprescindível escutar as necessidades e aspirações dos pacientes, como ele enxerga sua patologia, sua saúde, e desta forma, realmente promover saúde.

O profissional que trabalha com atividades de educação e promoção de saúde precisa olhar com mais cautela seu paciente, buscando conhecer e compreender o mundo em que vivem, e, a partir daí, saber fazer um manejo de estratégias de cuidado para atingir melhores resultados no decurso do tratamento de saúde.

É de grande significância a atuação do fisioterapeuta no hospital, desenvolvendo as práticas no sentido de promoção de saúde, desenvolvendo grandes benefícios tanto para a instituição, como para a sociedade em geral, que passará a ter um profissional mais completo e integrado aos novos desafios dos serviços de saúde no que concerne à busca da integralidade e equidade em saúde. 
ANEXOS 


\section{ANEXO 01 - APROVAÇÃO COMITÊ DE ÉTICA HCFMUSP}

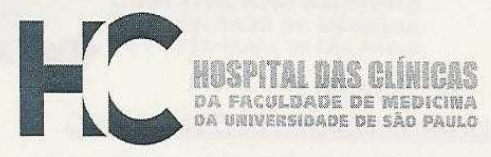

\section{APROVAÇÃO}

A Comissão de Ética para Análise de Projetos de Pesquisa CAPPesq da Diretoria Clínica do Hospital das Clínicas e da Faculdade de Medicina da Universidade de São Paulo, em sessão de 30/01/2008, APROVOU o Protocolo de Pesquisa n 1217/07, intitulado: "CARACTERIZAÇĀO DAS PRÁTICAS DE PROMOÇĀO DA SAÚDE NO ATENDIMENTO FISIOTERAPÊUTICO A PACIENTES COM DOENÇA ARTERIAL CORONARIANA." apresentado pelo Departamento de MEDICINA PREVENTIVA, inclusive o Termo de Consentimento Livre e Esclarecido.

Cabe ao pesquisador elaborar e apresentar à CAPPesq, os relatórios parciais e final sobre a pesquisa (Resolução do Conselho Nacional de Saúde n 196, de 10/10/1996, inciso IX.2, letra "c").

Pesquisador (a) Responsável: Herácliło Barbosa de Carvalho

Pesquisador (a) Executante: Denise Gonçalves Moura Pinheiro

CAPPesq, 11 de Fevereiro de 2008
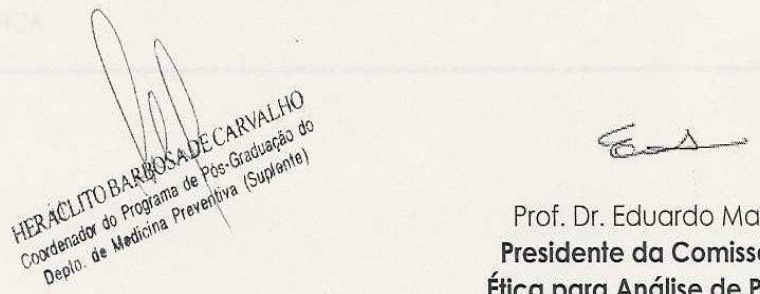

Prof. Dr. Eduardo Massad Presidente da Comissão de Ética para Análise de Projetos de Pesquisa

Comissão de Ética para Análise de Projetos de Pesquisa do HCFMUSP e da FMUSP Diretoria Clinica do Hospital das Clinicas da Faculdade de Medicina da Universidade de São Paulo Rua Ovídio Pires de Campos, 255, 50 andar - CEP 05403010 - São Paulo SP Fone: 01130696442 Fax: 01130696492 e-mail: cappesq@hcnet.usp.br/ secretariacappesq2@hcnet.usp.br

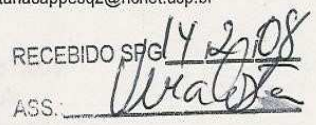


ANEXO 02- Folheto 1 da Atividade (2): Aula Pré e Pós- operatório.
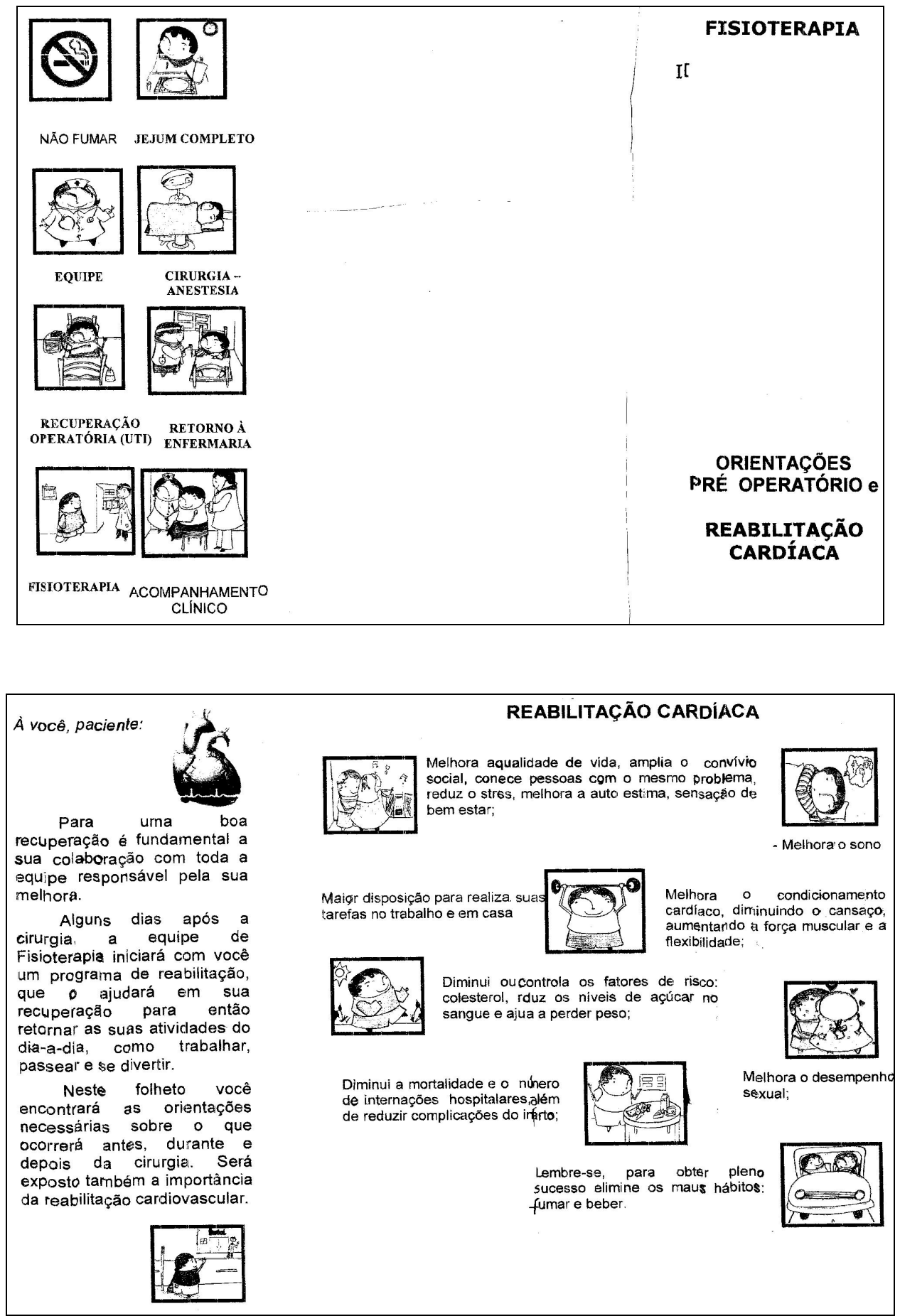
ANEXO 03 - Folheto 2 - Atividade (2): Aula do pré e pós-operatório Recomendações específicas para caminhada

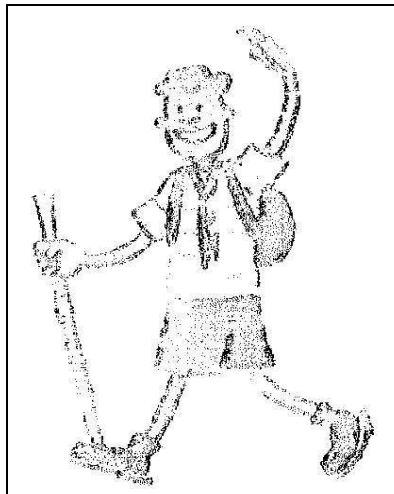

CAMINHADA

o custo dessa atividade física é muito baixo e pode ser realizada em praticamente qualquer lugar. Seja na rua, nos parques, na praia, no campo, ginásios, ou na área interna dos grandes centros comerciais, realmente qualquer lugar serve para quem quer dar uma boa caminhada. Como todo exercício aeróbico, é importante que a caminhada se prolongue por pelo menos 20 minutos. Isso é necessário para promover a melhora no condicionamento físico.

Para quem não tem o hábito de exercitar, comece aos poucos, porém de três a cinco vezes por semana:

- Após o alongamento; comece caminhando na primeira semana 5 minutos;

- 2a.Semana, aumente para 10 minutos;

- 3a. Semana caminhe 15 minutos;

- 4a. Semana caminhe 20 minutos;

- 5a. Semana caminhe 30 minutos.

- OBSERVACÃO: Durante os alongamentos e caminhada, observe o ritmo de seu coração e seu cansaço. Use roupas leves e um tênis macio. Beba líquido antes, durante e depois da caminhada.

$\longrightarrow$ Sem cansaço $\longrightarrow$ Prossiga

$\longrightarrow$ Pouco cansado $\longrightarrow$ Prossiga mas fique atento

$\longrightarrow$ Quando cansativo $\longrightarrow$ PARE

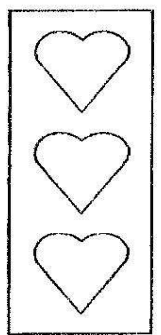


- Estique um dos braços para frente e puxe o dorso da mão no sentido do antebraço com a ponta dos dedos para cima. Em seguida, puxe a palma da mão para baixo. Repita os dois movimentos com o outro braço.
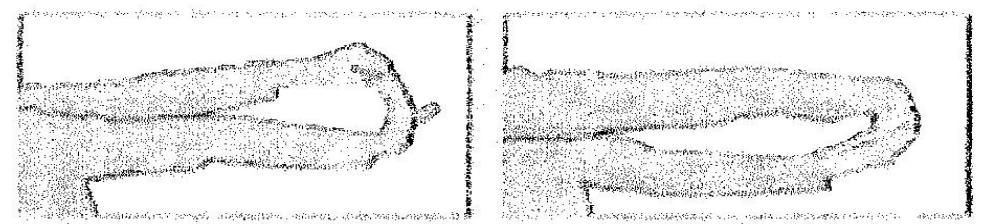

- Apóie uma das mãos na parede e a outra segure a ponta do pé. Repita com a outra perna. Caso você não alcance o pé, peça ajuda a alguém ou apóie o pé numa cadeira.

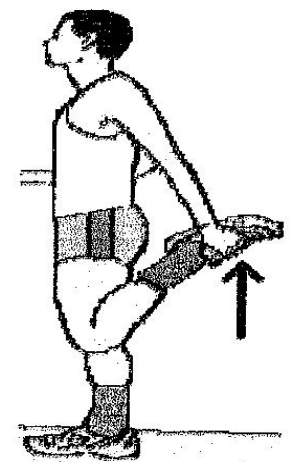

- Com as mãos apoiadas na parede, coloque uma das pernas na frente e deixe a perna de trás bem estendida; dobre a perna da frente e sinta a perna de trás alongando. Repita do outro lado.

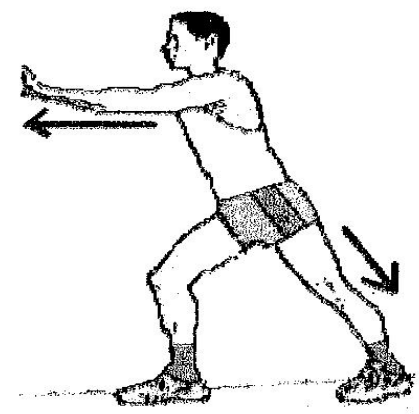




\section{ANEXO 04 - Folheto 3 - Atividade (2): Aula do pré e pós-operatório - Orientações de exercícios para casa}

\section{ORIENTACÕES DE EXERCÍCIOS PARA CASA}

A seguir seguem-se instruções para se realizar exercícios físicos em casa de uma maneira segura eficaz. Hoje em dia sabe-se da importância de praticar atividade física para pessoas com problemas cardiacos, hipertensão, diabetes, entre outros. Com os exercicios você melhora sua qualidade de vida, obtém sensação de bem estar e mais disposição para realizar todas as suas atividades diárias.

\section{Instrucões para iniciar suas atividades:}

- Os exercícios mais recomendados são: bicicleta ergométrica, esteira ou caminhada. Escolha o qual for mais conveniente e de sua disponibilidade. A caminhada deve ser realizada em local plano e seguro. De preferência realize os exercícios sempre no mesmo horário para que a mesmo se torne um hábito. Pratique os exercícios por 40 minutos à 1 hora por dia, pelo menos 3 vezes por semana.
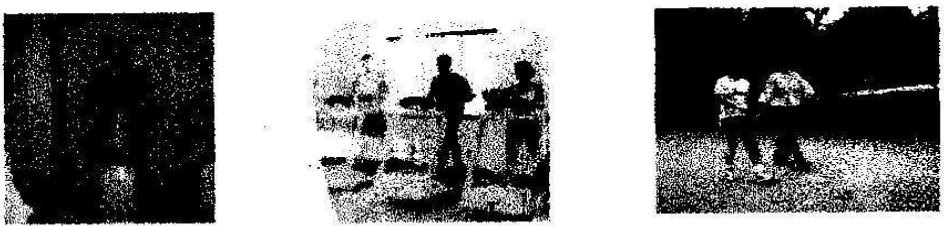

- Aprenda a checar o seu pulso e habitue-se a avaliá-lo logo após o exercicio
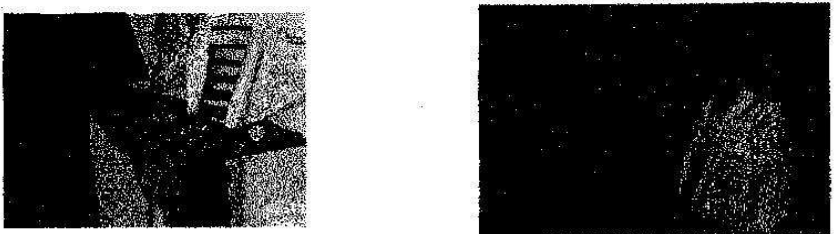

- A sua frequência cardíaca ideal para treinamento é de

\section{ATENCX̃O: SUSPENDA OU DIMINUA A INTENSIDADE DA ATIVIDADE SE VOCÊ SENTIR :}

- Dor ou pressão no peito, no pescoço, no maxilar ou no braço esquerdo.

- Palpitações: sensação de batimentos fortes do coração on "batedeira".

- Dificuldade para respirar.

- Vertigem ou sensação de desmaio e fraqueza.

- Suor frio no rosto, visão embaraçada ou escurecida.

- Náuseas (sensação de vomitar)

- A escala de Borg é importante para que você avalie seu cansaço durante o exercício. 0 ideal ó mantó a núta 13 (ligoiramente cansativo). 


\begin{tabular}{|c|c|}
\hline 6 & $\Leftrightarrow$ \\
\hline 7 & $\Rightarrow$ muito,muito fácil \\
\hline 8 & $\Rightarrow$ \\
\hline 9 & $\Rightarrow$ muito lácil \\
\hline 10 & $\Leftrightarrow$ \\
\hline 11 & $\Rightarrow$ fácil \\
\hline 12 & $\Leftrightarrow$ \\
\hline$\$ 3$ & $\begin{array}{l}\rightarrow \text { ligeiramente } \\
\text { cansativo }\end{array}$ \\
\hline 1:4 & $\Leftrightarrow$ \\
\hline 15 & - cansativo \\
\hline 16 & $\Leftrightarrow$ \\
\hline 17 & $\Rightarrow$ muito cansativo \\
\hline 18 & $\Rightarrow$ \\
\hline 19 & $\Leftrightarrow$ exaustivo \\
\hline 20 & $\Leftrightarrow$ \\
\hline
\end{tabular}

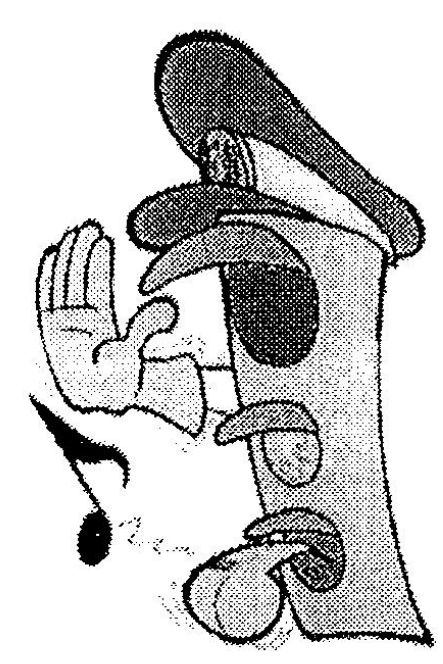

- Realize os seguintes alongamentos para os braços e pernas antes e depois da atividade fisica. Permaneça em cada posição por 10 segundos. Conforme sentir facilidade, aumente lentamente o tempo do alongamento para 20 seguntos. Cuidado para não prender a respiração durante os alongamentos.
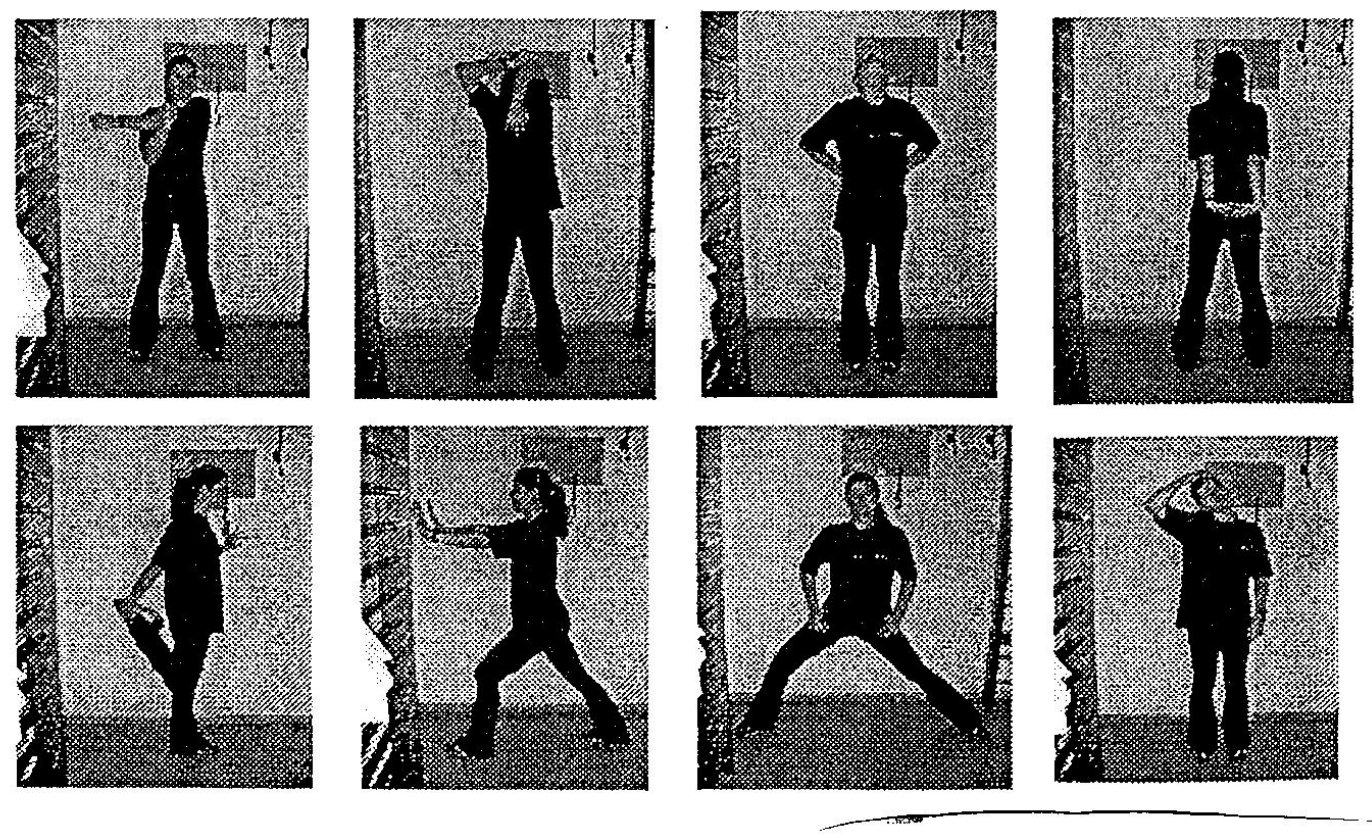
ANEXO 05 - Ficha de controle diário de exercícios em casa . Atividades (2) e (7): Aula do pré e pós-operatório e grupo GLPP

\section{CONTROLE DIÁRIO DE EXERCÍCIOS EM CASA}

\begin{tabular}{|c|c|c|c|}
\hline DATA & $\begin{array}{c}\text { CAMINHADA } \\
\text { (minutos) }\end{array}$ & CANSACO & $\begin{array}{c}\text { PRESSĂO } \\
\text { ARTERIAL }\end{array}$ \\
\hline & & & \\
\hline & & & \\
\hline & & & \\
\hline & & & \\
\hline & & & \\
\hline & & & \\
\hline & & & \\
\hline & & & \\
\hline & & & \\
\hline & & & \\
\hline & & & \\
\hline & & & \\
\hline & & & \\
\hline & & & \\
\hline & & & \\
\hline & & & \\
\hline & & & \\
\hline & & & \\
\hline & & & \\
\hline & & & $\theta$ \\
\hline & & & \\
\hline & & & \\
\hline & & & \\
\hline & & & \\
\hline & & & \\
\hline & & & \\
\hline & & & \\
\hline & & & \\
\hline & & & \\
\hline & & & \\
\hline & & & \\
\hline
\end{tabular}

OBS: Trazer em todas as consultas do setor e mostrar ao fisioterapeuta Pressão arterial = marcar toda vez que verificar. Se você tem aparelho em casa, verifique antes do exercício. Se sua PA estiver acima de 170 X 100 não faça exercícios nesse dia. 


\section{ANEXO 06 - Folheto de orientação de exercícios - Programa Anti- Tabagismo}

Lembre-se

Está provado que exercícios leves são muito eficientes para melhorar o humor e para aliviar o estresse.

Exercícios aeróbicos três vezes por semana ajuda a aliviar os sintomas da TPM.

Exercícios moderados ajudam a melhorar o sono, e você se sente mais descansado no dia seguinte.

Exercícios aeróbicos regulares ajudam a manter elásticos os vasos sangüíneos, o que por sua vez contribui para a saúde do coração.

Exercícios diminuem o colesterol (não somente o LDL, o mau colesterol, mas os triglicérides).

Um treinamento balanceado aumenta a densidade dos ossos.

Exercícios geralmente aumentam a tolerância à glicose, que é a capacidade do seu corpo de usar glicose para energia em vez de armazená-la talvez como gordura. Esta é uma das razões pela qual aqueles que se exercitam têm menos tendência a ficar acima do peso do que a pessoa sedentária.

\section{Orientação de Exercícios}

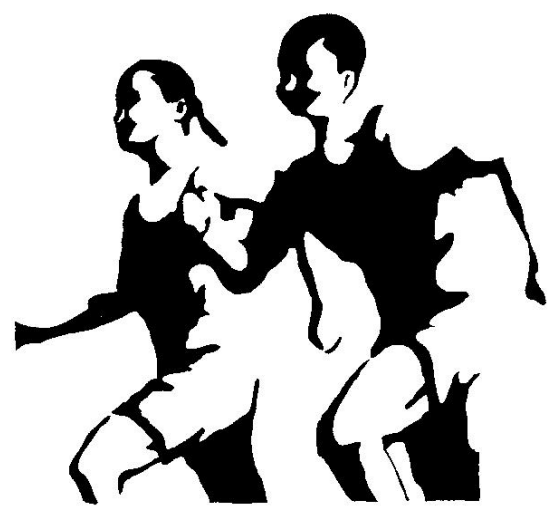


Imporkância da Prática de Exercícios

Hoje sabemos que é muito importante fazer exercícios físicos. Com eles você pode meIhorar sua qualidade de vida, obter sensação de bem estar e mais disposiçāo para realizar todas as suas atividades diárias.

A seguir instruções para fazer exercícios de maneira segura e eficaz.

Os exercícios mais recomendados são:

- Bicicleta Ergométrica;

- Esteira ou Caminhada;

\section{Pratique ao menos 30 minutos por dia} no mínimo 3 vezes por semana.

Benefícios: Previne e auxilia no controle a hipertensão, reduz os níveis de colesterol, ativa a circulação sanguínea, diminui o risco de infarto, melhora a capacidade cardiopulmonar e melhora também a freqüenencia cardíaca.

\section{Atenção}

Nāo iniciar ou diminuir a intensidade do exercício se você sentir:

- Dor ou pressão no peito, pescoço, maxilar ou no braço esquerdo:

- Palpitações (sensação de batimentos fortes do coração ou "batedeira").

- Dificuldade para respirar.

- Vertigem ou sensaçāo de desmaio e fraqueza. - Suor frio no rosto, visão embaçada ou escurecida.

- Náuseas (Vontade de vomitar)

\section{Avaliando seu Nivel de Cansaço}

A escala de Borg é muito importante para que você avalie seu cansaco durante o exercício.

$\mathrm{O}$ ideal é manter a nota $4 \mathbf{2}$. (Ligeiramente cansativo),

Escala de Borg

\begin{tabular}{|l|l|}
\hline 0 & Nenhuma \\
0,5 & Muito, muito leve \\
1 & Muito leve \\
2 & Leve \\
3 & Moderada \\
4 & Um pouco forte \\
\hline 5 & Forte \\
6 & \\
7 & Muito forte \\
8 & \\
9 & Muito, muito forte \\
10 & Máxima \\
\hline
\end{tabular}

Alongamentos

Realize os seguintes alongamentos para os braços e pernas antes e depois da atividade. Permaneça em cada posição 20 segundos e não prenda a respiração durante os alongamentos.
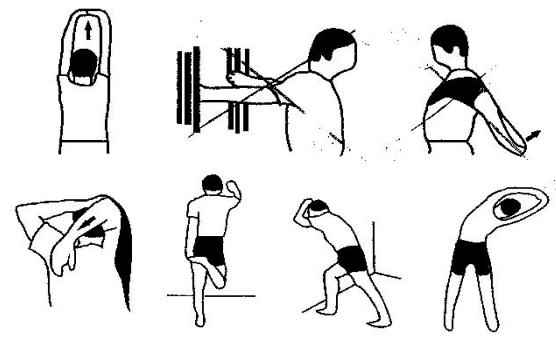

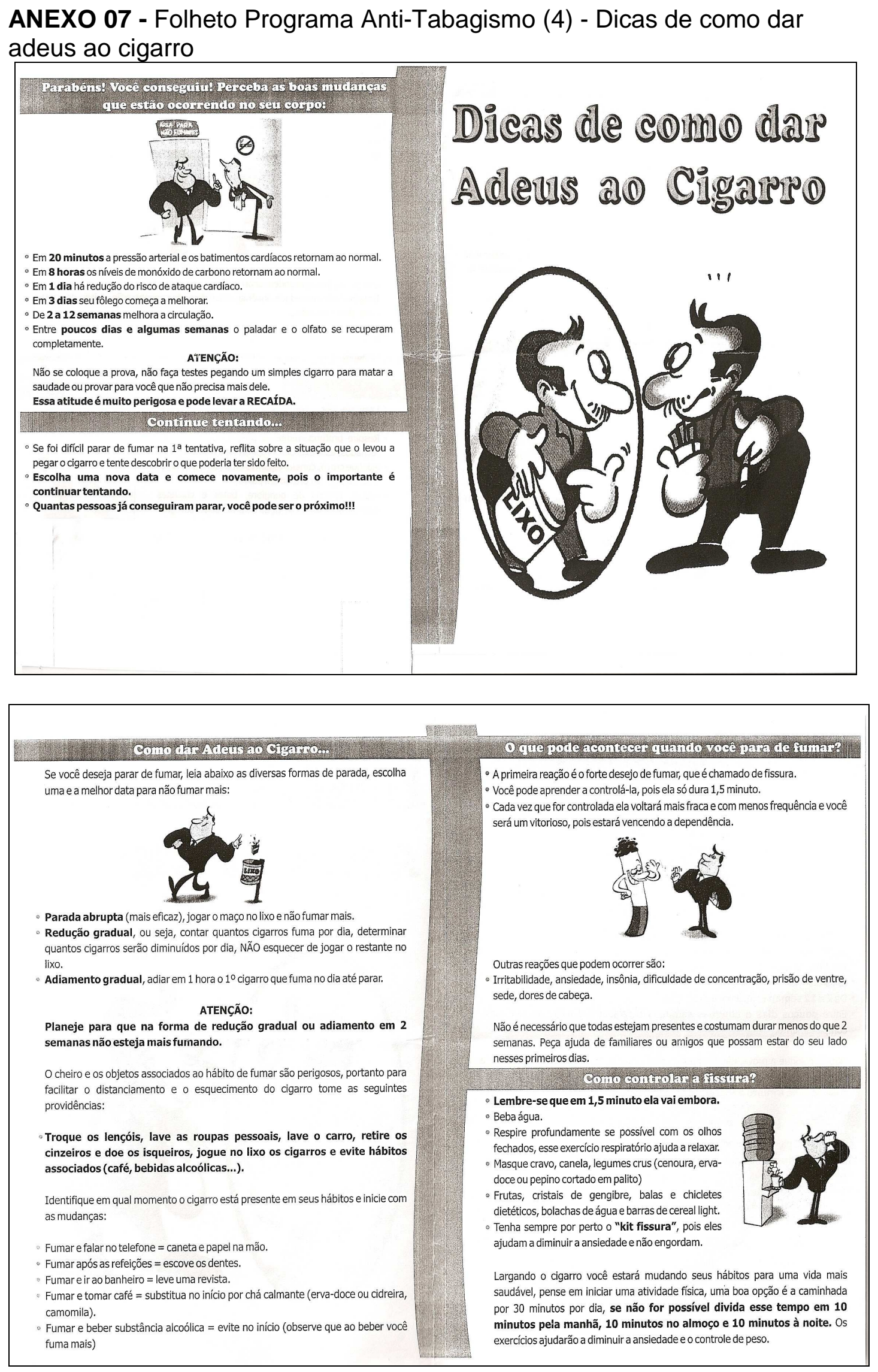
ANEXO 08 - Folheto do Programa Anti-Tabagismo (4) - Orientações para cessação do tabagismo

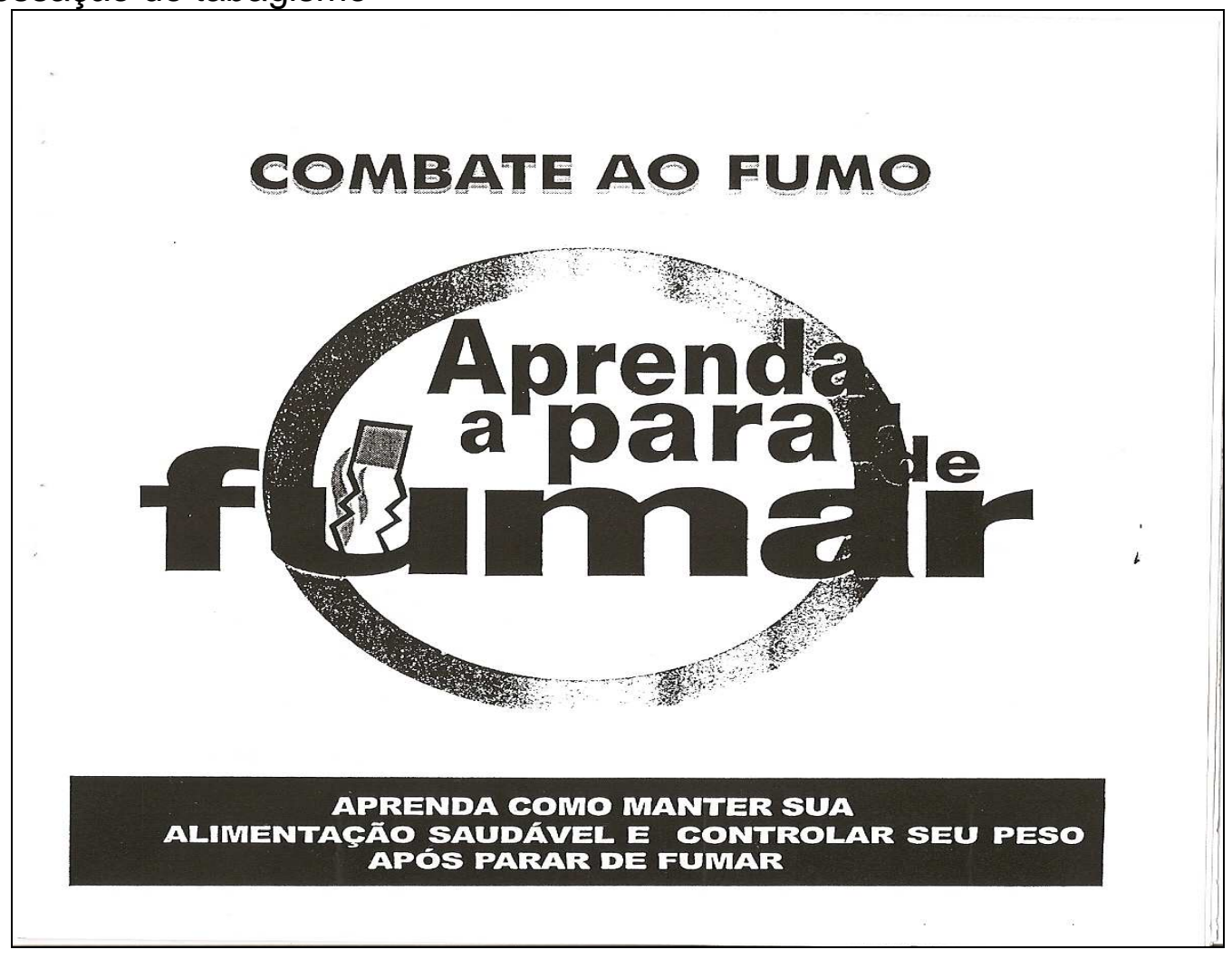




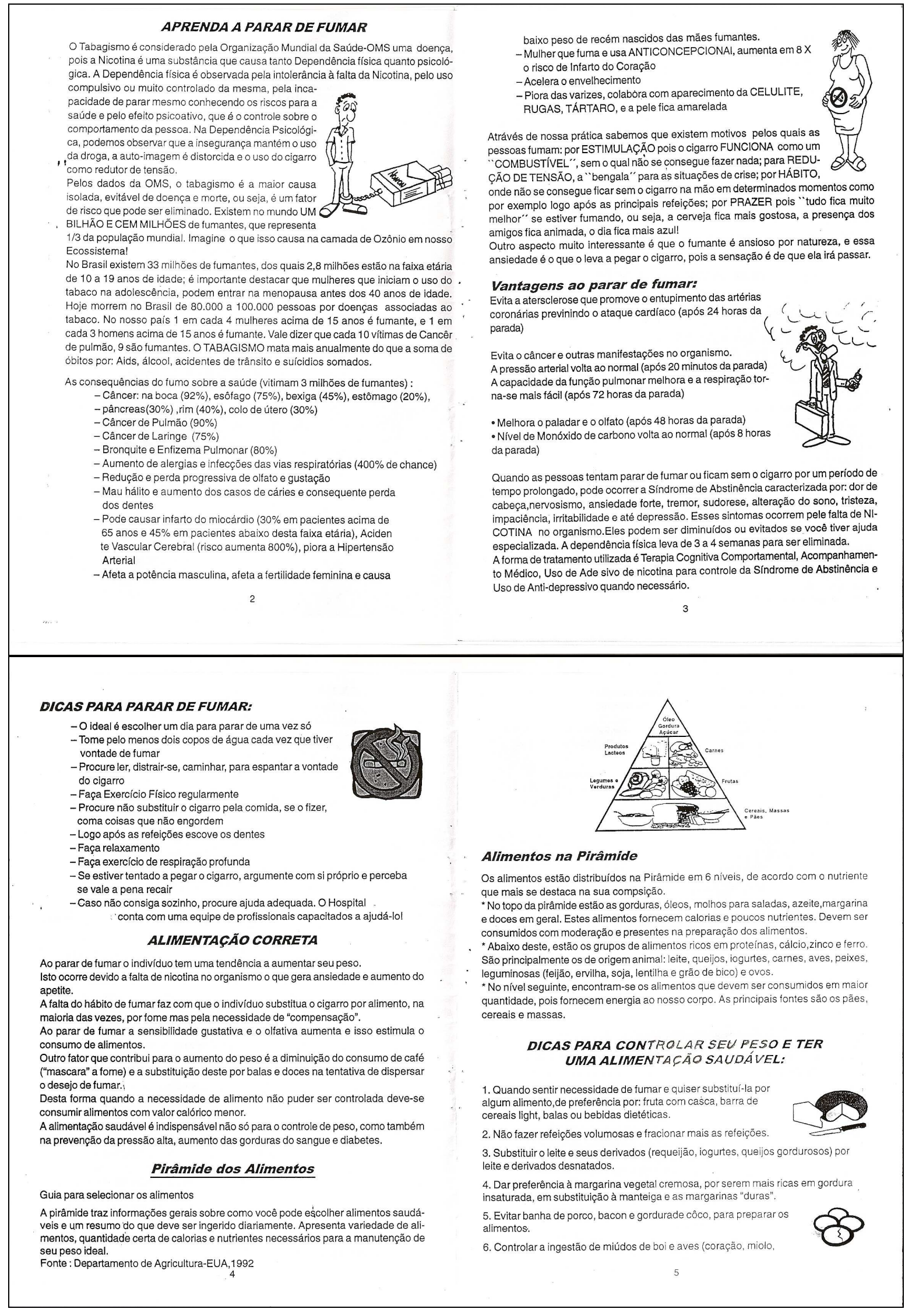


tigado).

7. Evitar o consumo de carnes gordurosas, como picanha,cupim, contrafile, linguiça e também os embutidos (presunto, salame, mortadela,

salsicha)

8. Retirar a pele do frango antes do cozimento.

9. Controlar a ingestão de frutos do mar (camarão, ostra, lula, marisco,

polvo), devido ao alto teor de colestero.

10. Preparar as carnes, aves e peixes ensopados, grelhadas ou

assadas, grelhadas ou assadas

11. Dar preterência aos óleos vegetais: soja, milho, girassol, canola

e oliva, utilizar o mínimo necessário para refogar alho e cebola. no controle do colesterol. As principais fontes são: farelo de aveia, cereais matinais,

13. Evitar molhos de maioneses, queijos gordurosos, creme de leite,

azeite de dendê.

14. Controlar a ingestão de chocolates, doces com cremes e chantilly, lothados e mousses.

15. Consumir alimentos dietéticos com moderaçăo.

16. Consumir maior quantidade de leguminosas ( feijão, lentilha, ervilha, grão de bico), frutas, verduras e cereais,

17. Quando "comer fora", avaliar e selecionar os alimentos e pratos, antes de fazero pedido, esclarecendo modo de preparo e quais ingredientes compõe o prato escolhido.

\section{EXERCICIO E TABAGISMO}

O hábito de fumar freqüentemente está associado à ocorrência de doenças do aparelho cardiovascular (liberaçāo de substâncias que promovem alteração da viscosidade do sangue, aumento da frequência cardiaca e contração dos vasos sanguineos) e do pulmão (câncer e enfisema pulmonar). Geralmente vem acompanhado de sedentarismo e diminuição da porcentagem de massa muscular no corpo.

Quando se analisou individuos fumantes, sedentários e obesos em relação ao risco de ocorrência de doença arterial coronariana, atestou-se que as mulheres tem o risco aumentado em dez vezes, quando comparadas com não fumantes. No caso de homens, o risco fica aumentado em até cinco vezes.

O Benefícios do exercicio tísico: 1) melhora a força e flexibilidade dos músculos, melhorando a tolerância aos estorços; 2) Quando associado a dieta favorece a perda de peso; 3) Melhora a sensação de bem estar; 4) Protege quanto a evolução de osteoporose; 5) Melhora a flexibilidade e a mobilidade articular; 6) Diminui os valores da pressăo arterial em repouso e duran do colesterol "ruim", aumentando o "bom" colesterol; 8) Melhora a sensibilidade a insulina; 9) Favorece a dilatação dos vasos pulmonares, melhorando as trocas gasosas; 10) Diminui a incidência de câncer.

Odano cardiovascular do cigarro supera todos os benefícios provocados la atividade física. Um indivíduo que deixa fumar tem sua capacidade física pela atividade fisica. Um individuo que deixa fumar tem sua capacidade fisica
significativamente aumentada com cerca de sete dias de abstinência dos cigarros.

\section{Plano de Execução de exercícios}

- Selecione atividades que Ihe sejam agradáveis e que utilizem grandes grupos

musculares( ciclismo, natação, caminhada e corrida).

- Decida quando, onde e com que frequeencia elas serão realizadas, Inicie com

cerca de $30^{\prime}$, após parar de fumar a atividade física realizada diariamente auxilia na

perda de peso.

- Aumente a intensidade dos exercícios gradativamente, exercícios muito intensos

podem predispor a lesões

- Faça uma tabela : tipo de exerć́cio/duração/dia da semana e registre o seu

a

- Utilize roupas e calçados confortáveis(tênis)

.Beba áqua antes, durante e após a realizaçăo dos exercicios.

Cada indivíduo deve ter a sua programação de exercício individualizada, levandose em conta as preferências individuais, fatores de risco e estado inicial de condicionamento físico.

O exercício físico precipita a fadiga física e produz efeitos relaxantes podendo ter um efeito facilitador do sono, sendo indicado para individuos que relataram distúrbios de sono com a abstinência ao cigarro.

Encare o exercício com um hábito diário que deve ser executado por toda a 
ANEXO 9 - Folheto do Programa Anti-Tabagismo (4) - Exercícios de
relaxamento

\section{EXERCÍCIOS DE RELAXAMENTO}

O objetivo deste exercício é ajudá-lo a aprender como relaxar seu corpo voluntariamente. É uma técnica para se praticar sempre, mas é especialmente valiosa para os primeiros dias sem cigarros. Pode-se selecionar uma das três técnicas ou até mesmo praticar as três, porém é importante que seja praticada diariamente.

Você pode ler os exercícios ou pedir para alguém ler para você, porém precisa ser de maneira calma e devagar.

\section{EXERCÍCIO DE RESPIRAÇÃO PROFUNDA}

Fique em pé, com os pés afastados, joelhos ligeiramente flexionados, ombros bem colocados, porém relaxados, colocando-se de maneira mais confortável possível. Em seguida feche os olhos e deixe a cabeça pender para frente.

Deixando sua cabeça pender um pouco mais agora, sem tensionar o pescoço, inspire pelo nariz lentamente. Respire profundamente deixando o abdômen se expandir enquanto você inspira. Prenda um pouco sua respiração e agora expire devagar.

Coloque o ar para fora através de seu nariz. Não se apresse e repita esse exercício quatro vezes em seu próprio ritmo. Faça isso lentamente. Pare por alguns instantes se você se sentir tonto. Não se apresse $e$, quando se sentir pronto, abra seus olhos devagar.

\section{EXERCÍCIO DE RELAXAMENTO MUSCULAR}

Fique em pé com os pés firmemente plantados no chão, joelhos ligeiramente flexionados, ombros soltos, postura correta. Agora, feche os olhos. Pressione seus pés a faça um movimento com os pés como se fosse agarrar o chão. Aperte mais. 
8. Os nervos e músculos de seu corpo agora querem comente descansar

9. Tudo em você, agora quer descansar:

10. Você está totalmente relaxado.

Imagine-se agora caminhando calma e lentamente, descendo por uma trilha na relva de um morro, em direção a um riacho de águas límpidas e tranqüilas. É se manhã cedor e o sol morno está brilhando. $O$ ar é fresco e perfumado. Você pode sentir o cheiro gostoso do capim. Às vezes um peixe pula no riacho; o riacho brilha na claridade da manhã, transparente e muito tranquiilo. Você se senta lentamente na relva, à beira do riacho, e sente-se tranqüilo. Uma brisa suave balança o capim levemente, e você olha para o céu azul, onde há nuvens bem brancas flutuando. Você se deita na relva, olha as nuvens e começa a flutuar ao encontro delas. Você é capaz de andar sobre as nuvens, e isso é divertido.

A temperatura está agradável, e o ar é limpo e fresco; o céu é azul, e as nuvens são macias, brancas e fofas. Você sente o sol morno $e_{r}$ quando respira, sente todo o seu corpo se encher com ar fresco e limpo. Você está totalmente relaxado. Nesse momento, reafirme seu desejo de parar de fumar. Pense no seu compromisso em atingir essa meta. Você tem certeza de que irá conseguir. Aproveite para mentalizar uma data para deixar de fumar. Pense nela novamente. Você vai conseguir. Mantenha essa sensação de conquista consigo. Agora lentamente, comece a despertar.

Você está aqui, sentado em sua cadeira, e ainda se sente bem. Muito relaxado e com muita energia. Aproveite essa sensação e procure mantê-la consigo durante todo o dia. Quando estiver pronto, abra lentamente os olhos e sorria. 
ANEXO 10- Fotos do Programa de Reabilitação Cardíaca

Figura 1: Exercícios de alongamento

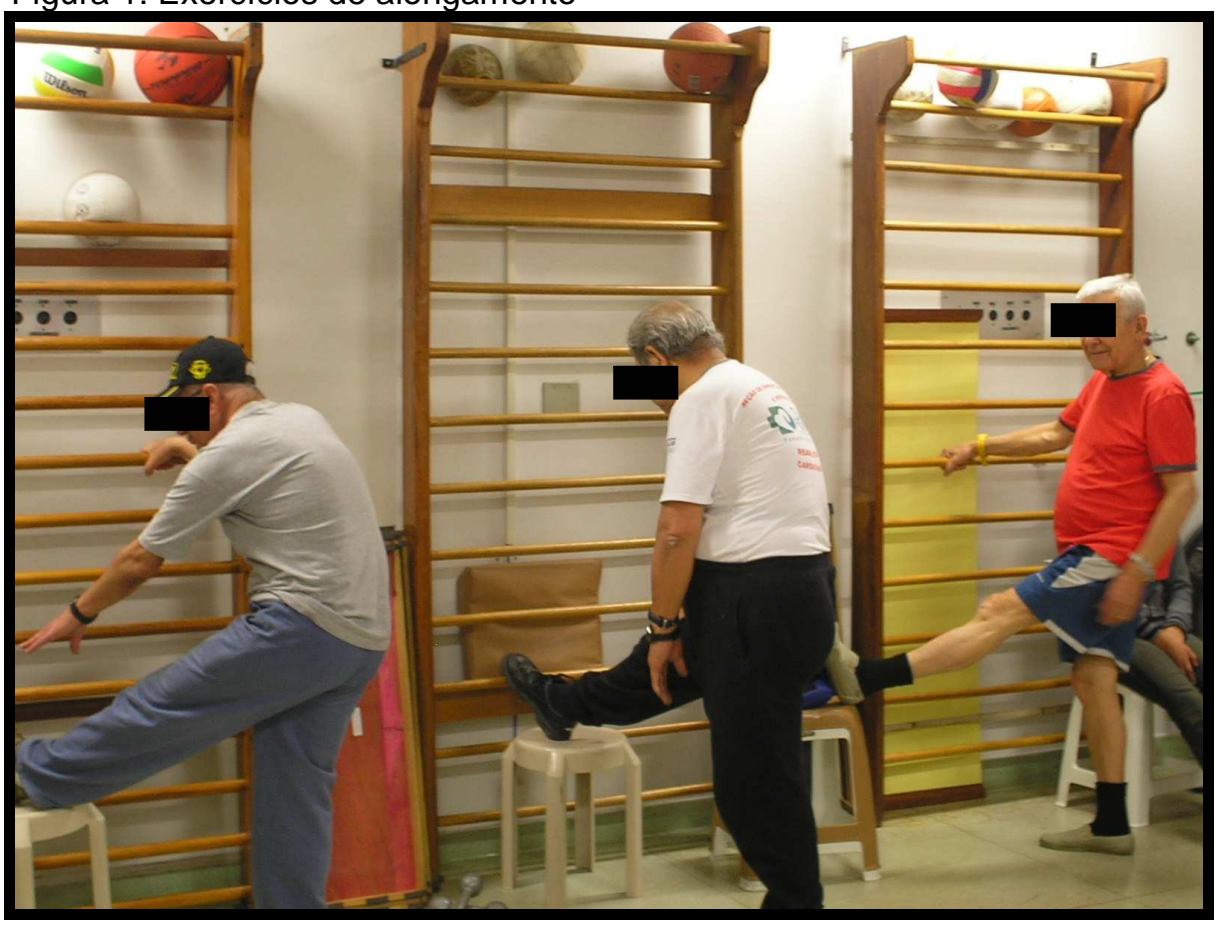

Figura 02: Exercícios de aquecimento

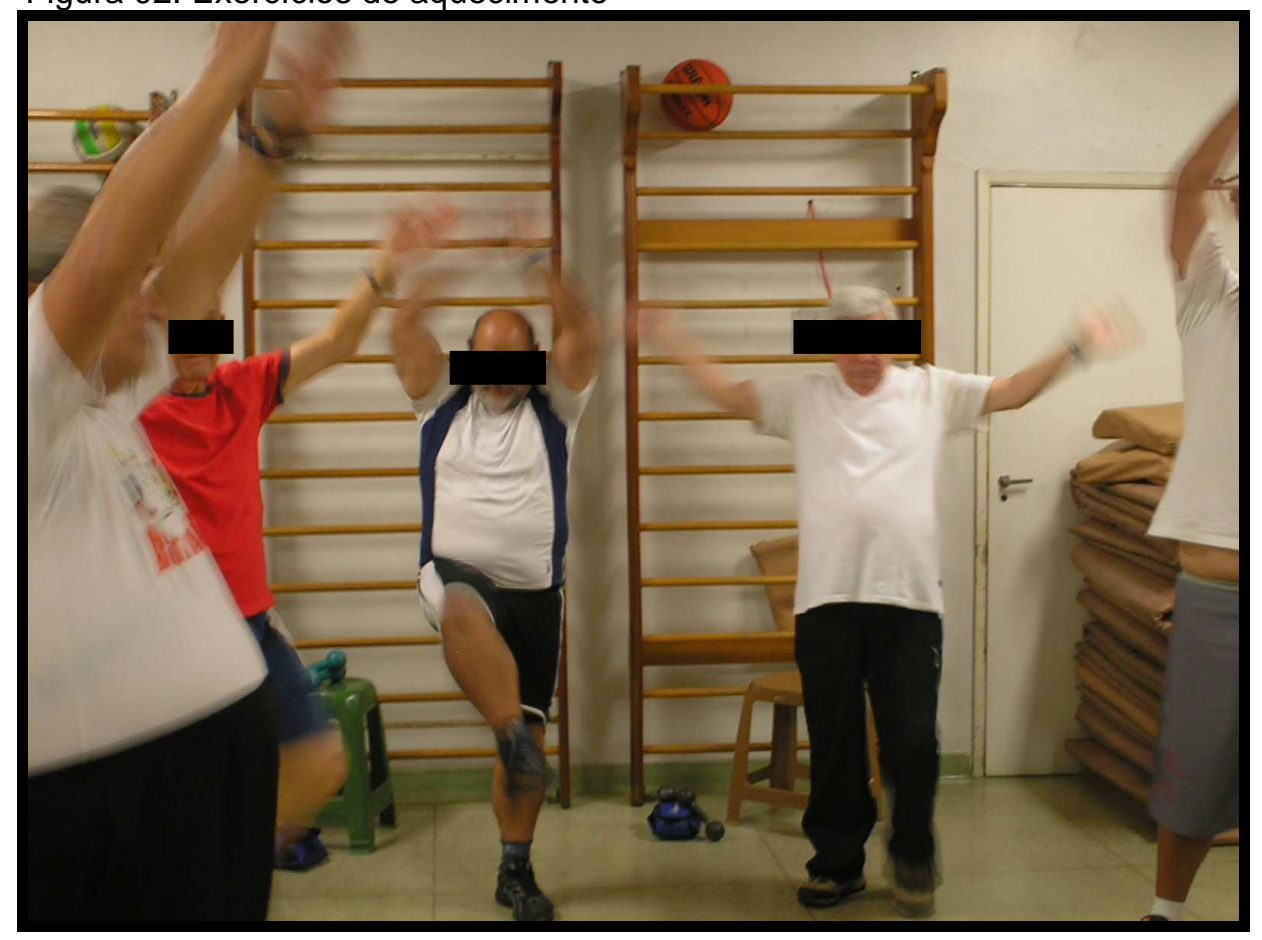


Figura 03: Exercícios resistidos para membros superiores

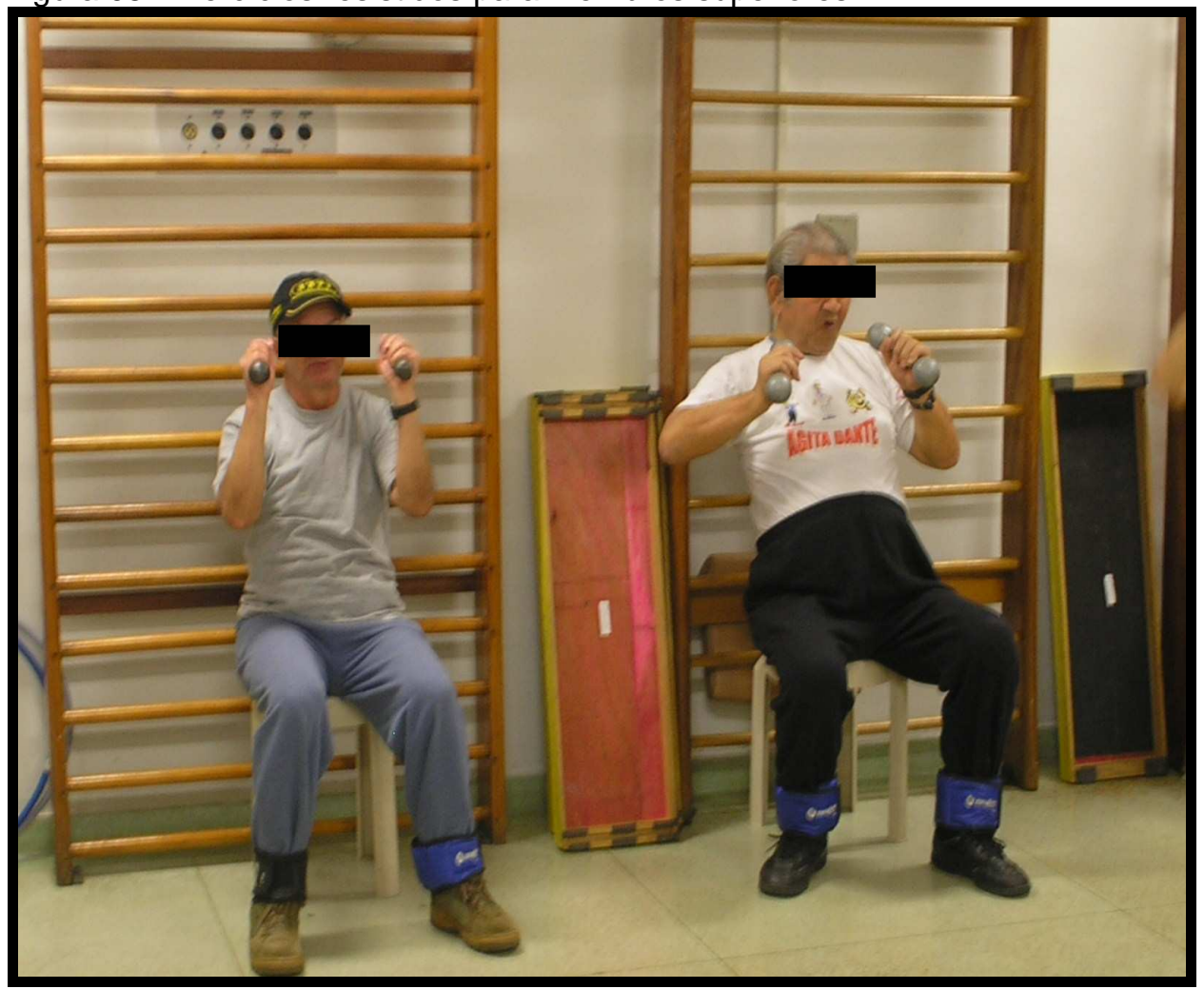

Figura 04: Os pacientes são constantemente monitorados em sua freqüência cardíaca

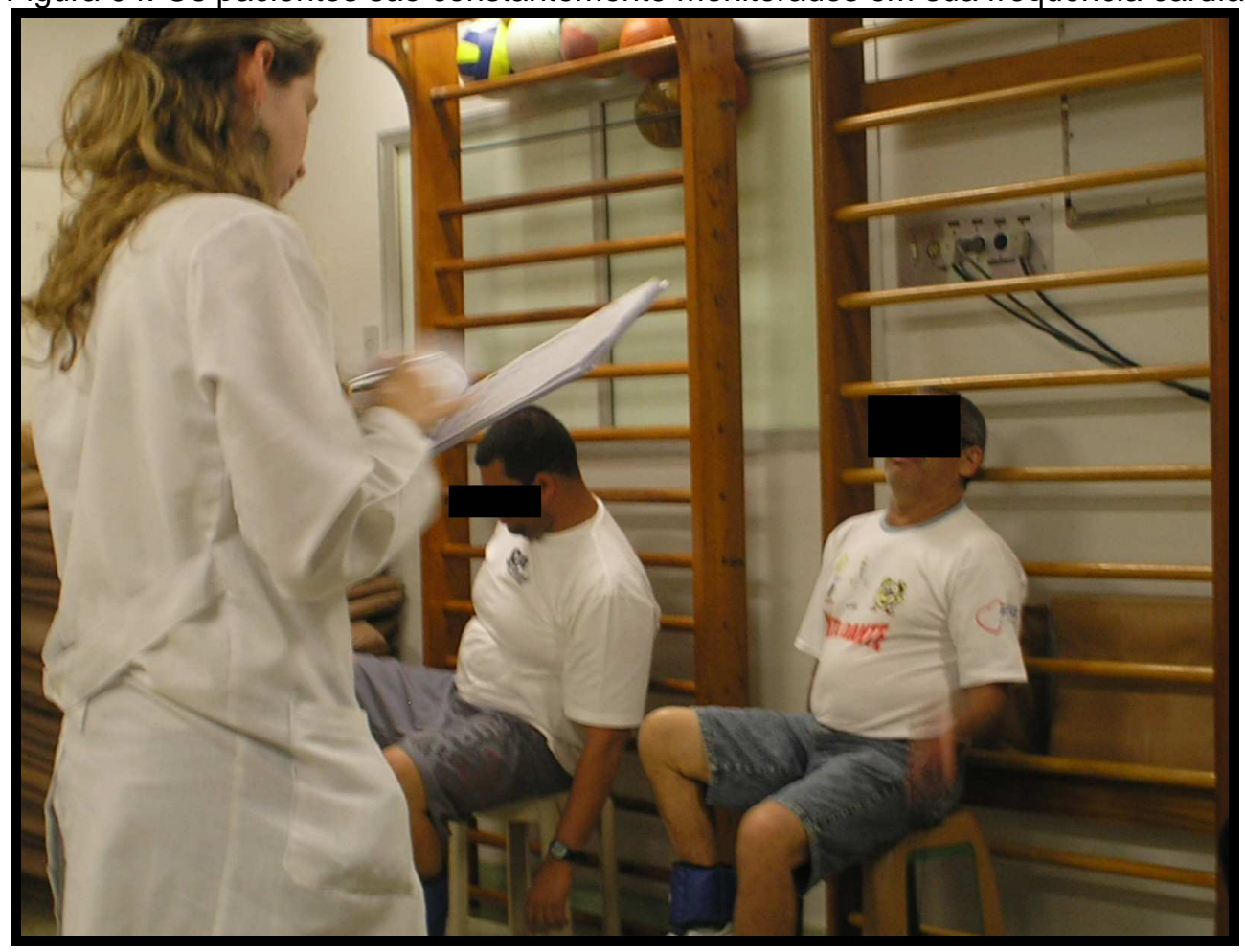


Figura 05: Exercícios resistidos para membros inferiores com auxílio da barra

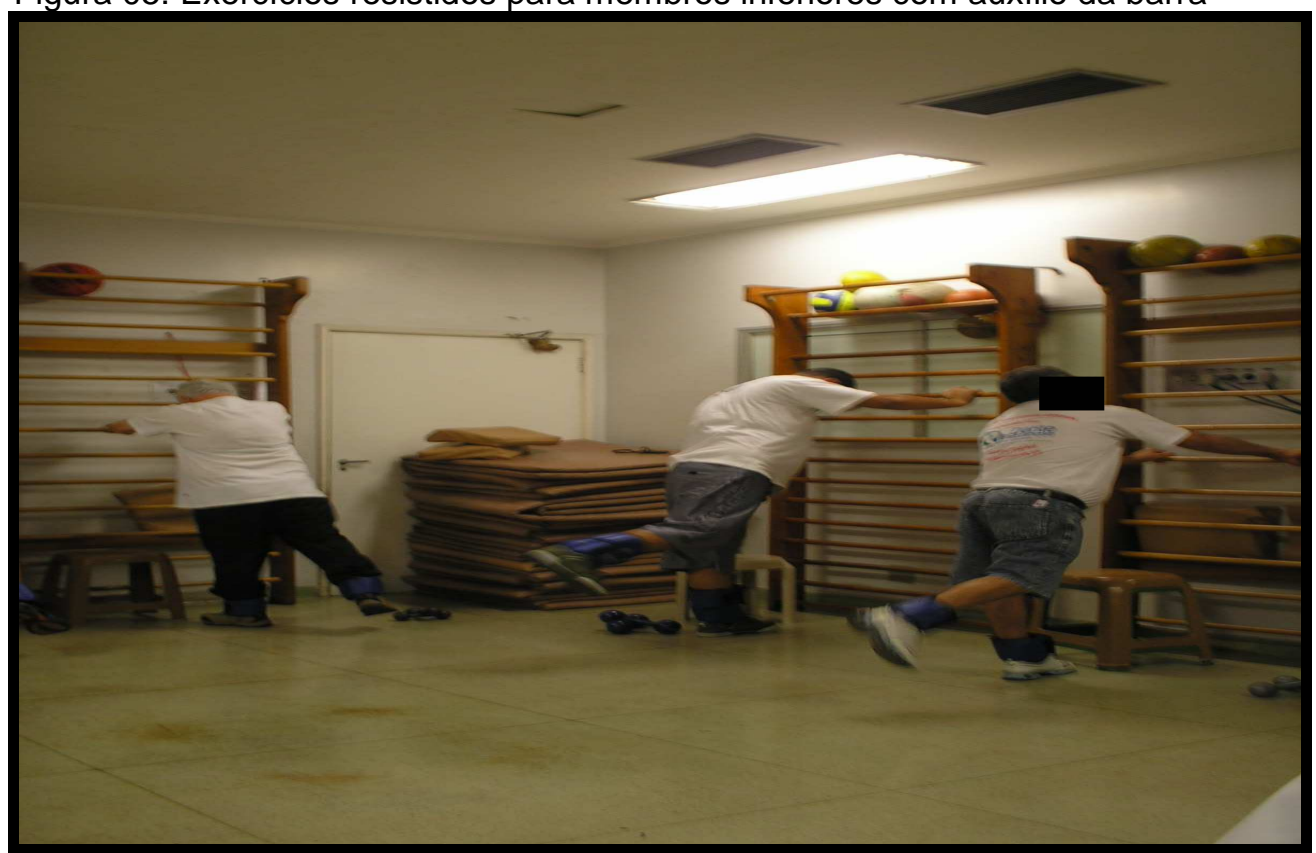

Figura 06: Exercícios aeróbios na bicicleta ergométrica

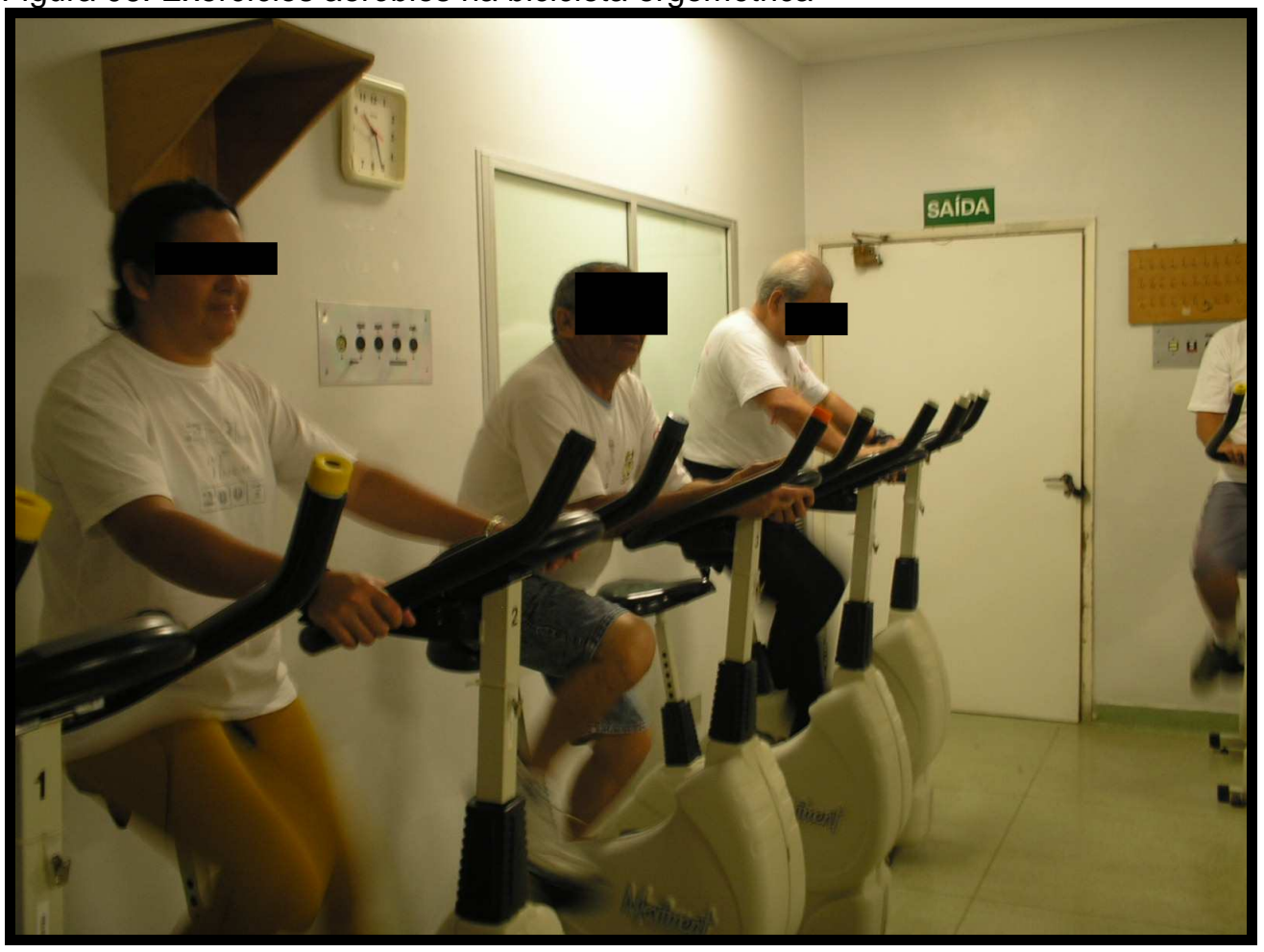


Figura 07 : Alongamentos finais

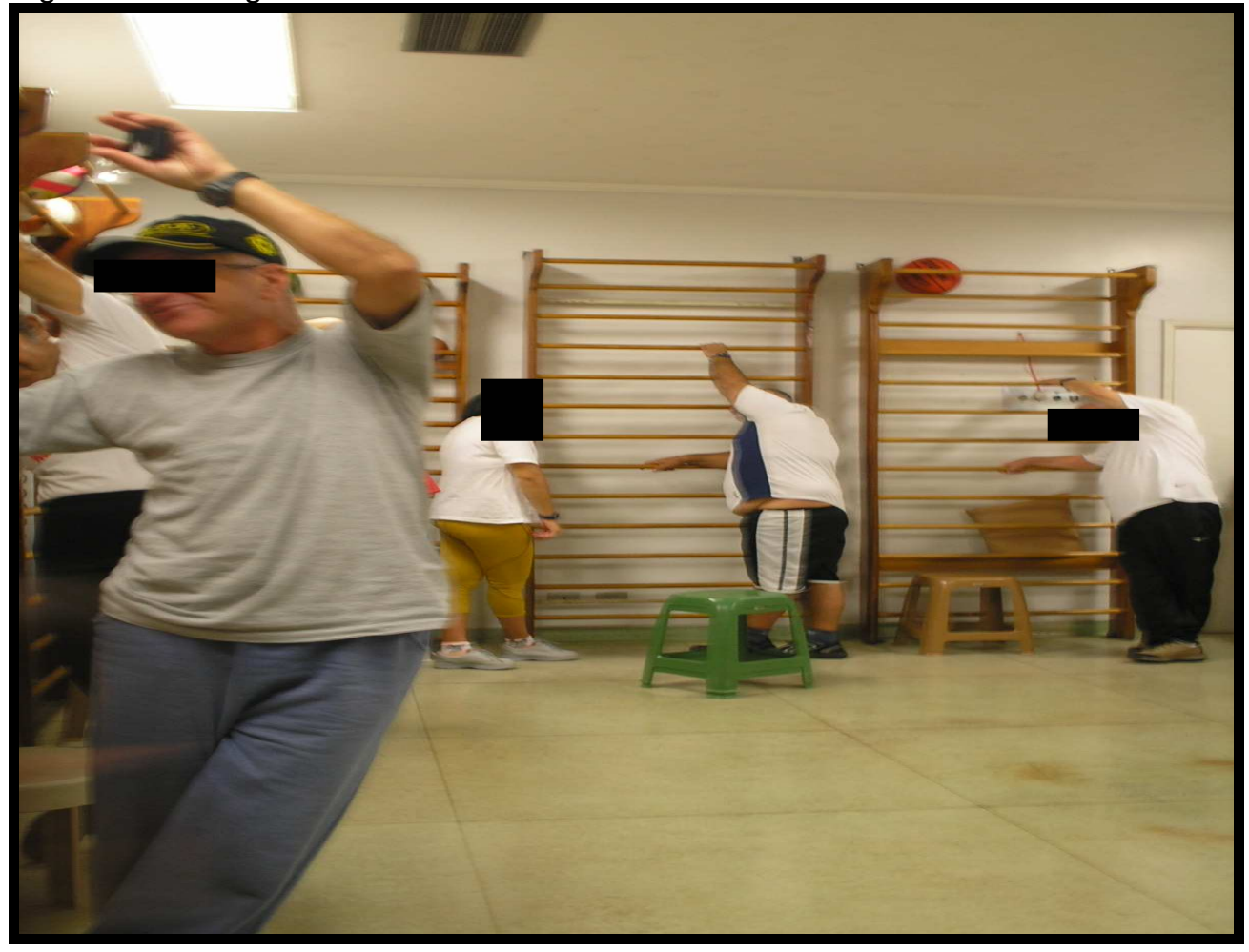

Figura 08: Alongamento sob supervisão do fisioterapeuta

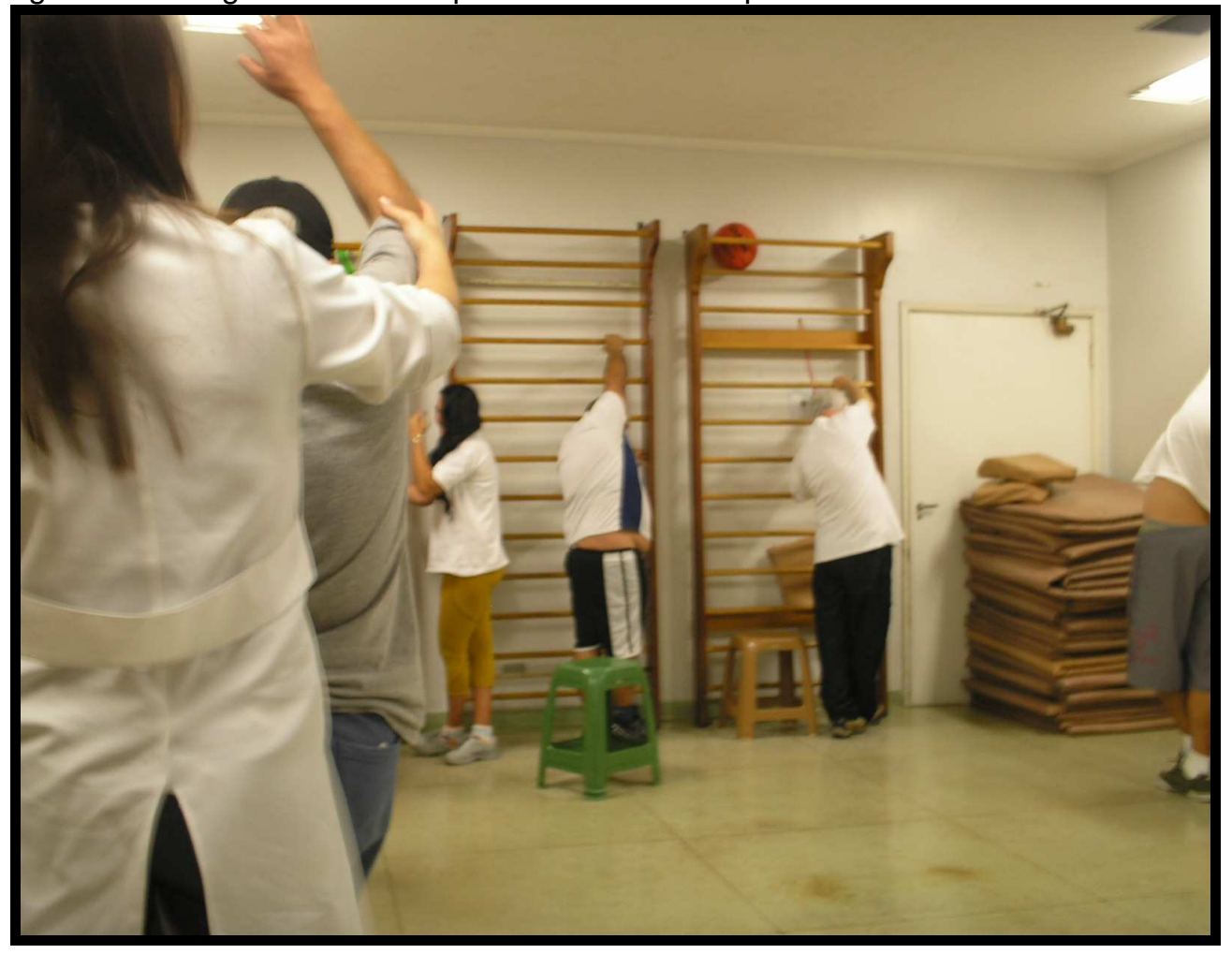


APÊNDICES 


\section{APÊNDICE 01 - TERMO DE CONSENTIMENTO LIVRE E ESCLARECIDO (Para Chefe do Setor de Fisioterapia)}

São Paulo, de 2008

Prezado Sr,

Estamos desenvolvendo um estudo sobre as práticas de promoção da saúde realizadas por fisioterapeutas no atendimento a cardiopatas nesta instituição hospitalar. Esta atividade refere-se à Dissertação do Curso de Mestrado em Medicina Preventiva, da Faculdade de Medicina da Universidade de São Paulo.

Para a realização deste estudo, precisamos da colaboração de $\mathrm{V} . \mathrm{Sr}^{\mathrm{a}}$, no que se refere à permissão para acompanhar os profissionais fisioterapeutas que atuam nesse hospital, com o objetivo de levantar dados para a presente pesquisa.

Da mesma forma, solicitamos a V.Sr ${ }^{\mathrm{a}}$ que nos conceda uma entrevista sobre as ações de promoção da saúde realizadas pelo serviço de Fisioterapia deste hospital.

Comprometemo-nos a manter sigilo sobre a identificação dos participantes do estudo e instituição. O nome do hospital e dos profissionais serão fictícios.

Contando com vossa preciosa colaboração e apoio, antecipamos os agradecimentos.

Atenciosamente,

Denise Gonçalves Moura Pinheiro

Aluna da Faculdade de Medicina da USP
Heráclito Barbosa de Carvalho

Prof ${ }^{\circ}$ Orientador da

Faculdade de Medicina - USP

IImo Sr, 


\section{APÊNDICE 02 - TERMO DE CONSENTIMENTO LIVRE E ESCLARECIDO (Para Fisioterapeutas)}

Título da pesquisa: Práticas de Promoção da Saúde no atendimento fisioterapêutico em uma instituição hospitalar de referência em Cardiologia Pesquisadora Responsável: Denise Gonçalves Moura Pinheiro Orientador: Heráclito Barbosa de Carvalho

A pesquisadora Denise Gonçalves Moura Pinheiro, fisioterapeuta, com o $R G n^{\circ}$ , inscrita no CREFITO-SP sob o número , está realizando um estudo que tem por objetivo caracterizar as práticas relacionadas à promoção da saúde dos fisioterapeutas que trabalham com cardiopatas. Este estudo refere-se a uma pesquisa de mestrado em Medicina Preventiva da Faculdade de Medicina da Universidade de São Paulo. Fui convidado a participar da pesquisa, permitindo que a pesquisadora me acompanhe durante as atividades com os pacientes e respondendo a uma entrevista. Minha participação na pesquisa não é obrigatória, mas será de grande importância se desejar fazê-lo.

Minhas informações serão tratadas com o mais absoluto sigilo, não sendo publicado meu nome e nem qualquer outro dado colhido que possa me identificar. A qualquer momento posso pedir informações e esclarecimentos a respeito da pesquisa, bem como retirar minha autorização para participação na mesma, o que não acarretará nenhum prejuízo a mim.

$\mathrm{Eu}$, recebi os devidos esclarecimentos a respeito da pesquisa acima, aceito participar de forma livre e espontânea, estou livre para em qualquer momento, desistir de colaborar com a pesquisa, sem nenhuma espécie de prejuízo. Recebi uma cópia deste termo, assinando este documento com a garantia de ter minha identidade preservada.

São Paulo, de de

Assinatura:

Assinatura do Pesquisador Responsável

\section{Dados do Pesquisador Responsável:}

Denise Gonçalves Moura Pinheiro

E-mail: denisep@usp.br 


\section{APÊNDICE 03 - TERMO DE CONSENTIMENTO LIVRE E ESCLARECIDO (Para os pacientes)}

Título da pesquisa: Práticas de Promoção da Saúde no atendimento fisioterapêutico em uma instituição hospitalar de referência em Cardiologia Pesquisadora Responsável: Denise Gonçalves Moura Pinheiro Orientador: Heráclito Barbosa de Carvalho

A pesquisadora Denise Gonçalves Moura Pinheiro, fisioterapeuta, com o $R G n^{\circ}$ inscrita no CREFITO-SP sob o número , está realizando um estudo que tem por objetivo caracterizar as práticas relacionadas à promoção da saúde dos fisioterapeutas que trabalham com cardiopatas. Este estudo refere-se a uma pesquisa de mestrado em Medicina Preventiva da Faculdade de Medicina da Universidade de São Paulo. Fui convidado a participar da pesquisa, respondendo a uma entrevista com a pesquisadora. Minha participação na pesquisa não é obrigatória, mas será de grande importância se desejar fazêlo.

Minhas informações serão tratadas com o mais absoluto sigilo, não sendo publicado meu nome e nem qualquer outro dado colhido que possa me identificar. A qualquer momento posso pedir informações e esclarecimentos a respeito da pesquisa, bem como retirar minha autorização para participação na mesma, o que não acarretará nenhum prejuízo a mim.

$\mathrm{Eu}$, recebi os devidos esclarecimentos a respeito da pesquisa acima, aceito participar de forma livre e espontânea, estou livre para em qualquer momento, desistir de colaborar com a pesquisa, sem nenhuma espécie de prejuízo. Recebi uma cópia deste termo, assinando este documento com a garantia de ter minha identidade preservada.

São Paulo, de de

Assinatura:

Assinatura do Pesquisador Responsável

\section{Dados do Pesquisador Responsável:}

Denise Gonçalves Moura Pinheiro

E-mail: denisep@usp.br 


\section{APÊNDICE 04 - FORMULÁRIO PARA ENTREVISTA (Para Chefe do Setor de Fisioterapia)}

1.Como é a rotina do paciente que se interna aqui no hospital? Qual tipo de morbidade cardiovascular mais prevalente na instituição? Quais os procedimentos de promoção da saúde realizados tanto na UTI quanto na Enfermaria?

2.Como funciona a assistência fisioterapêutica no ambulatório? Há ambulatório de hipertensão arterial? E de insuficiência cardíaca? Há algum programa anti-tabagismo? Se sim, como funciona? Há algum programa direcionado a pacientes com diabetes mellitus e obesidade? Se sim, qual é e como funciona? Se não, por quê não há?

3.Que tipos de atividades em promoção da saúde o hospital oferece a seus pacientes? Como o fisioterapeuta participa nessas ações?

4.Há algum programa oferecido à comunidade em geral, ou seja, para pacientes que não são do hospital?

5.Há um setor de reabilitação cardíaca no hospital? Se sim, como ele funciona? Para que tipo de morbidade cardiovascular ele é indicado, isto é qual é o tipo de pacientes mais prevalente nesse programa?

6.E em relação àqueles pacientes que recebem alta do hospital, ou que terminaram seu tratamento no ambulatório, existe um acompanhamento desses pacientes, visitas domiciliares, por exemplo?

7.O hospital promove campanhas de prevenção? Se sim, há dias temáticos? Que tipo de prevenção é desejada, primária ou secundária? Como o fisioterapeuta da instituição participa nessas campanhas?

8. As atividades de promoção em saúde, educação em saúde e o programa de reabilitação cardíaca são direcionados apenas à pacientes da instituição ou aqueles de outras instituições públicas/privadas também podem participar? Isso ocorre de fato? Se sim, como os pacientes são indicados ou tomam conhecimento desses programas?

9.Para você, o que são atividades de promoção em saúde?

10.Você considera as atividades de promoção importantes na fisioterapia cardiovascular? Por quê?

11. Você acha que dos últimos anos para cá algo mudou em relação à prática do fisioterapeuta cardiovascular relacionado à promoção da saúde dos pacientes? Como? 
12. Você acha que atualmente os pacientes com doenças cardiovasculares estão sabendo mais a respeito de sua patologia, formas de tratamento e prevenção? Você avalia um melhor autocuidado por parte dos pacientes da instituição? Por que?

13. Há projetos novos do setor de fisioterapia em relação ao atendimento dos pacientes, atividades de promoção em saúde?

14.De acordo com sua experiência, quais os principais obstáculos à implantação dessas atividades de promoção em saúde com pacientes cardiovasculares nesse tipo de instituição (hospitalar)?

15.Gostaria de acrescentar algo? Fazer mais alguma consideração? 


\section{APÊNDICE 05- FORMULÁRIO PARA ENTREVISTA (Para}

Fisioterapeutas)

1- Para você, o que são atividades de promoção em saúde?

2- Você considera as atividades de promoção importantes na fisioterapia cardiovascular? Por quê?

3- Você acha que dos últimos anos para cá algo mudou em relação à prática do fisioterapeuta cardiovascular relacionado à promoção da saúde dos pacientes? Como?

4- Você acha que atualmente os pacientes com doenças cardiovasculares estão sabendo mais a respeito de sua patologia, formas de tratamento e prevenção? Você avalia um melhor auto-cuidado por parte dos pacientes da instituição? Por que?

5- De acordo com sua experiência, quais os principais obstáculos à realização dessas atividades de promoção em saúde com pacientes cardiovasculares aqui no hospital?

6 - Gostaria de acrescentar algo? Fazer mais alguma consideração? 


\section{APÊNDICE 06 - FORMULÁRIO PARA ENTREVISTA (Para pacientes)}

Sexo:

Idade:

Tratamento que realiza no hospital:

1) O que o senhor(a) entende sobre saúde?

2) No momento, o senhor(a) se considera uma pessoa com saúde?Por que?

3) Qual o motivo pelo qual freqüenta o hospital?

4) Quais as atividades que participa no hospital?

5) Gosta destas atividades?Tem dificuldade em vir $p /$ estas atividades?

6) O que aprendeu de novo sobre saúde aqui no hospital?

7) Quais as dificuldades que o senhor(a) sente ao fazer seu tratamento?

8) Antes de freqüentar o hospital, o que o senhor(a) sabia sobre sua doença/tratamento?Já participou de alguma atividade que falasse sobre saúde em outro local?

9) O senhor(a) se sente capaz de realizar seu tratamento? Por que?

10)O que gostaria de saber sobre saúde ? E o que gostaria de aprender sobre saúde aqui no hospital? 


\section{APÊNDICE 07: ROTEIRO DE OBSERVACÃO E ACOMPANHAMENTO DOS FISIOTERAPEUTAS}

\section{1) Atendimento UTI / Enfermaria}

a)Orientações pré-operatórias/ pós- operatórias:

Espaço físico da sala/ Distribuição das cadeiras

Participação dos pacientes

Tipo de abordagem do fisioterapeuta/ Abordagem dialógica

Quantidade de pacientes/acompanhantes

Recomendações individuais/ gerais

Uso de uma linguagem acessível $\mathrm{p} /$ os pacientes

Interesse dos pacientes/ acompanhantes

Interesse do profissional $\mathrm{p} /$ com os pacientes

Explicação dos folhetos

Estímulo à atividade física

Duração da atividade

Dúvidas/questionamento dos pacientes

\section{2) Programas de atividade física: Reabilitação Cardíaca/ Grupos}

Espaço físico da sala/ Ventilação / Tamanho

Duração da atividade

Orientação individual/ Grupal

Quantidade de pacientes no total

Quantidade de fisioterapeutas

Quantidade de profissionais $\mathrm{p} /$ cada paciente

Motivação dos pacientes

Condição dos aparelhos/ Quantidade adequada

Monitoração contínua dos pacientes

Adequada auto-monitoração pelos pacientes

\section{3) Programa Anti-Tabagismo}

Quantidade de pessoas no grupo

Espaço físico da sala/ Distribuição de cadeiras

Motivação dos pacientes

Motivação dos profissionais

Recomendações inviduais / gerais

Consultas individuais com os profissionais da equipe

Abordagem dialógica

Linguagem acessível

Explicação dos folhetos

Interação entre os pacientes 
Interação entre pacientes/ profissionais

\section{4) Aulas}

Espaço físico da sala/ Distribuição das cadeiras Participação dos pacientes

Tipo de abordagem dos profissionais / Abordagem dialógica Quantidade de pacientes/acompanhantes

Recomendações individuais/gerais

Uso de uma linguagem acessível $\mathrm{p} /$ os pacientes

Interesse dos pacientes/acompanhantes

Interesse do profissional $\mathrm{p} /$ com os pacientes

Explicação dos folhetos

Estímulo à mudança nos estilos de vida

Dúvidas/questionamento dos pacientes

Duração da aula 


\section{REFERÊNCIAS}

Alfieri RG, Furlan V, Rodrigues MJ. A decisão clínica na avaliação do pósinfarto agudo do miocárdio. Rev Bras Cli Ter. 2002; 28 (2):74-81.

Alves VS. Um modelo de educação em saúde para o programa de saúde da família: pela integralidade da atenção e reorientação do modelo assistencial. Interface- Comun. Saúde e educ. 2005; 9 (16): 39-52.

Augustine E. Papel interdisciplinar do fisioterapeuta. In: O'Nouny et al. Segredos em Medicina Física e de Reabilitação. Porto Alegre: ArtMed; 2000.

Balady GJ, Ades PA, Comoss P et al. Core components of Cardiac Rehabilitation/Secondary Prevention Programs: A Statement for healthcare Professionals From the American Herat Association and the American Association of Cardiovascular and Pulmonary Rehabilitation Writing Group. Circulation. 2000; 102: 1069-1073.

Baumann AE. Updating the evidence that physical activity is good for health: an epidemiological review 2000-2003. J Sci Med Sport. 2004; 7(sup 1): 6-19.

Becker HS. Métodos de Pesquisa em Ciências Sociais. São Paulo: Hucitec; 1994.

Boesch C, Myers J, Habersaat A, llarraza H, Kottman W, Dubach P. Maintenance of exercise capacity and physical activity patterns 2 years after cardiac rehabilitation. J Cardiopulm Rehabil. 2005; 25(1):14-21.

Brasil. Ministério da Saúde. Política Nacional de Promoção da Saúde. Brasília: Ministério da saúde; 2006.

Broszkiewicz M, Sobala W, Drygas W. Predictors of smoking cessation in group-based behavioral intervention programme--research findings in 20012007. Przegl Lek. 2008; 65 (10):634-40.

Brown RA. Rehabilitation of patients with cardiovascular diseases. Report of a WHO expert committee. World Health Organ Tech Rep Ser. 1964; 270: 346.

Busnello RG, Melchior R, Faccin C, Vettori D, Petter J, Moreira LB, Fuchs FD. Características associadas ao abandono do acompanhamento de pacientes hipertensos atendidos em um ambulatório de referência. Arq Bras Cardiol. 2001; 76 (5):349-51.

Buss PM. Uma introdução ao conceito de promoção da saúde. In: Czeresnia D, Freitas CM (orgs). Promoção da saúde: conceitos, reflexões, tendências. Rio de Janeiro: Editora Fiocruz; 2003. p.15-38. 
Campos GW, Barros RB, Castro AM. Avaliação de política nacional de promoção da saúde. Ciência e Saúde Coletiva. 2004; 9(3): 745-9.

Candeias, NMF. Conceitos de educação e de promoção da saúde: mudanças individuais e organizacionais. Rev Saúde Pública. 1997; 31(2): 209-213.

Carvalho T. Diretriz de reabilitação cardiopulmonar e metabólica: aspectos práticos e responsabilidades. Arq bras cardiol. 2006; 86(1):74-82.

Ceccato MV, loris RR, Laguna SA et al. O papel do fisioterapeuta na atenção primária à saúde em comunidades de baixa renda. Rev Fisioterapia em movimento.1992; 4(2): 83-98.

Centers for Disease Control and Prevention (CDC). Arthritis as a potential barrier to physical activity among adults with heart disease--United States, 2005 and 2007. MMWR Morb Mortal Wkly Rep. 2009;58(7):165-9.

Cobb SL, Brown DJ, Davis LL. Effective interventions for lifestyle change after myocardial infarction coronary artery revascularization. J Am Acad Nurse Pract. 2006;18(1):31-9.

Condon C, McCarthy G. Lifestyle changes following acute myocardial infarction: patients perspectives. Eur J Cardiovasc Nurs. 2006;5(1):37-44.

Conselho Nacional de Saúde - Ministério da Saúde: Diretrizes e normas regulamentadoras da pesquisa em seres humanos - Resolução 196, 1996.

Cruz Neto O. O trabalho de campo como descoberta e criação. In: Minayo MCS (org). Pesquisa social: teoria, método e criatividade. Petrópolis: Vozes; 1997.

Datasus. Mortalidade - Brasil 2004. [online]. Disponível em: http://www.datasus.gov.br.

Denzin NK. The Research Act. New York: McGraw-hill;1978.

Dias EC (org). Doenças relacionadas ao trabalho: manual de procedimentos para serviços de saúde. Ministério da Saúde (representação no Brasil da OPAS/OMS), colaboradores Idelberto Muniz et al, Brasília: Ministério da saúde;2001.

Eliasson M, Asplund K, Nasic S, Rodu B. Influence of smoking and snus on the prevalence and incidence of type 2 diabetes amongst men: the northern Sweden MONICA study. J Intern Med. 2004;256(2):101-10. 
Ford ES, Ajani UA, Croft JB, Critchley JA, Labarthe DR, Kottke TE, Giles $\mathrm{WH}$, Capewell S. Explaining the decrease in US deaths from coronary disease, 1980-2000. N Engl J Med. 2007;356 (23):2388-98.

Freire P. Educação como prática da liberdade. Rio de Janeiro: Paz e Terra; 1969.

Frontera WR, Dawson DM, Slovik DM. Exercício Físico e Reabilitação. São Paulo: Artmed; 1999.

Giannini SD, Forti N, Diament J. Cardiologia Preventiva. São Paulo:Atheneu; 2000.

Goldmeier S, Castro I. A teoria do autocuidado no manejo dos fatores de risco (obesidade, hipertensão e tabagismo) em pacientes pós-infarto agudo do miocárdio. AMRIGS. 2005; 49(3): 137-206.

Gool CHV, Kempen GIJM, Penninx BW, Deeg DJ, van Eijk JT. Chronic disease and lifestyle transitions: results from the longitudinal aging study Amsterdam. J Aging Health. 2007;19(3):416-38.

Heidmann ITSB, Almeida MCP, Boehs AE et al. Promoção à saúde: trajetória histórica de suas concepções. Texto contexto - Enferm. [online]. 2006, 15(2): 352-8.

Lalonde M. A new perspective on the health of Canadians. Ottawa:Health and welfare, 1974 .

Lavie CJ, Milani RV. Effects of cardiac rehabilitation and exercise training on exercise capacity, coronary risk factors, behavioral characteristics, and quality of life in women. Am J Cardiol. 1995; 75(5):340-3.

Leavell H, Clark EG. Medicina Preventiva. São Paulo: McGraw-Hill;1976.

Lebrão ML, Laurenti R. Saúde, bem-estar e envelhecimento: o estudo SABE no município de São Paulo 2005. Rev Bras Epidemiol. 2005; 8(2): 127-41.

Lenfant C. Can we prevent cardiovascular disease in low-midle- income countries? Bullettin of the World Health Organization. 2001; 79: 980-987.

Levantesi G, Macchia A, Marfisi RM et al. Metabolic Syndrome and risk of cardiovascular events after myocardial infarction. J Am Coll Cardiol. 2005; 46(2): 277-83.

Lima FET, Araújo TL. Correlação dos fatores condicionantes básicos para o autocuidado dos pacientes pós-revascularização do miocárdio. Rev. Bras. Enferm. 2005; 58(5):519-523. 
Lima FET, Lopes MVO, Araújo TL. A família como suporte para o idoso no controle da pressão arterial. Rev Família, Saúde e Desenv. 2001; 3(1): 63-9.

Marmot M. Economic and social determinants of disease. Bullettin of the World Health Organization. 2001; 79: 988-989.

Mcardle WD, Katch FI, Katch VL. Fisiologia do Exercício. Energia, nutrição e desempenho humano. 5 ed . Rio de Janeiro: Guanabara Koogan; 2003.

Medeiros ARC. Adesão ao tratamento anti-hipertensivo em unidade de saúde da família de João pessoa - PB. [dissertação] Paraíba: Faculdade de Enfermagem, Universidade Federal da Paraíba; 2006.

Milani RV, Lavie CJ, Cassidy MM. Effects of cardiac rehabilitation and exercise training programs on depression in patients after major coronary events. Am Heart J. 1996; 132(4):726-32.

Milani RV, Lavie CJ. Prevalence and effects of cardiac rehabilitation on depression in the elderly with coronary heart disease. Am J Cardiol. 1998;81 (10):1233-6.

Minayo MCS. O desafio do conhecimento. 7ed. São Paulo:Hucitec;2000.

Monteiro MF, Sobral Filho DC. Exercício físico e o controle da pressão arterial. Rev. Bras. Med. Esporte. 2004; 10(6): 513-6.

Motta LB, Aguiar AC. Novas competências profissionais em saúde e o envelhecimento populacional brasileiro: integralidade, interdisciplinaridade e intersetorialidade. Ciência e Saúde Coletiva. 2007;12(2): 363-372.

Murchie P, Campbell NC, Ritchie LD, Simpson JA, Thain J. Secondary prevention clinics for coronary heart disease: four year follow up of a randomised controlled trial in primary care. BMJ. 2003; 326(7380):84.

Myers J. Exercise and cardiovascular health. Circulation. 2003;107 (1):E2E5.

Negrão CE, Barretto ACP. Cardiologia do exercício. Do atleta ao cardiopata. São Paulo: Manole; 2005.

Nisbeth O, Klausen K, Andersen LB. Effectiveness of counselling over 1 year on changes in lifestyle and coronary heart disease risk factors. Patient Educ Couns. 2000; 40(2):121-31.

Olivi M, Oliveira MLF. Educação para a saúde em unidade hospitalar: um espaço profissional do enfermeiro. Ciência, Cuidado e Saúde. 2002; 2(2): 131-138. 
Pelicioni MCF, Pelicioni AF, Toledo RF. A educação e a comunicação para a Promoção da Saúde. In: Rocha AA, César CLG (org). Saúde Pública Bases conceituais. São Paulo: Atheneu;2008.

Pereira ALF. As tendências pedagógicas e a prática educativa nas ciências da saúde. Cad. Saúde Pública. 2003; 19(5):1527-1534.

Pinheiro DGM, Pinheiro CHJ, Marinho MJF. Estilo de vida e importância da educação em saúde na reabilitação cardíaca após cirurgia de revascularização do miocárdio. Rev. Bras. Prom. Saúde. 2007; 20(4): 21320.

Pryor JA, Webber BA. Fisioterapia para problemas respiratórios e cardíacos. Rio de Janeiro: Guanabara Koogan; 2002.

Rebelatto JR, Botomé SP. Fisioterapia no Brasil: fundamentos para uma ação preventiva e perspectivas profissionais. 2 ed. São Paulo: Manole;1999.

Regenga MM. Fisioterapia em Cardiologia: da U.T.I à reabilitação. São Paulo:Roca; 2000.

Ruiz, RC et al. Um mundo sem LER é possível. UITA; 2003.

Sanderson JE, Mayosi B, Yusuf S, Reddy S et al. Global burden of cardiovascular disease. Heart. 2007;93(10):1175.

Sanderson BK, Mirza S, Fry R, Allison JJ, Bittner V. Secondary prevention outcomes among black and white cardiac rehabilitation patients. Am Heart J. 2007;153(6):980-6.

Santos SO. Princípios e técnicas de comunicação. In: Junior AP, Pelicioni MCF. Educação ambiental e sustentabilidade. São Paulo:Manole;2005.

Santos LM, Ros MAD, Crepaldi MA, Ramos LR. Grupos de promoção à saúde no desenvolvimento da autonomia, condições de vida e saúde. Rev Saúde Pública. 2006; 40(2): 346-52.

Sheedy J, Smith B, Bauman A et al. A controlled trial of behavioural education to promote exercise among physiotherapy outpatients. Aust $J$ Physiother. 2000;46(4):281-289.

Sícoli JL, Nascimento PR. Promoção de saúde: concepções, princípios e operacionalização. Interface- comum, saúde e educ. 2003;17(12):101-22.

Silva E, Catai AM. Fisioterapia cardiovascular na fase tardia:fase III da reabilitação cardiovascular. In: Regenga MM, Fisioterapia em cardiologia: da UTI à reabilitação.São Paulo:Roca; 2000. p.261-310. 
Smeltzer SC, Bare BG. Tratado de enfermagem médico-cirúrgica. 8ed. Rio de Janeiro:Guanabara Koogan; 1998. p.34-43.

Sociedade de Cardiologia do Estado de São Paulo. Fisioterapia em Cardiologia. São Paulo: Atheneu;2007.

Song $\mathrm{R}$, Lee $\mathrm{H}$. Effects of a 12-week cardiac rehabilitation exercise program on motivation and health-promoting lifestyle. Heart Lung. 2001;30(3):200-9.

Stead LF, Lancaster T. Group behaviour therapy programmes for smoking cessation. Cochrane Database Syst Rev. 2005;18;(2).

Strömberg A, Mårtensson J, Fridlund B, Levin LA, Karlsson JE, Dahlström U. Nurse-led heart failure clinics improve survival and self-care behaviour in patients with heart failure:results from a prospective, randomised trial. Eur Heart J. 2003;24(11):1014-23.

Sundel KL, Stain-Mahngren R, Andersson A et al. High frequency of anxiety and angina pectoris in depressed women with coronary heart disease. Gend Med. 2007;4(2):146-56.

Torres HC, Franco LJ, Stradioto MA et al. Avaliação estratégica de educação em grupo e individual no programa educativo em diabetes. Rev Saúde Publica. 2005; 43(2): 291-8.

Umeda, IIK. Manual de Fisioterapia na Reabilitação Cardiovascular. São Paulo:Manole; 2005.

Ussher MH, Taylor A, Faulkner G. Exercise interventions for smoking cessation. Cochrane Database Syst Rev. 2008;8(4).

Zhao G, Ford ES, Li C, Mokdad AH. Are United States adults with coronary heart disease meeting physical activity recommendations? Am J Cardiol. 2008;101(5):557-61.

Zeller M, Steg PG, Raveisy J. et al. Prevalence and impact of MS on hospital outcomes in acute myocardial infarction. Arch Intern Med. 2005; 165(10):1192-8.

Yin RK. Case study research: design and methods. London: Sage;1984.

Yusuf S. Two decades of progress in preventing vascular disease. Lancet. 2002; 360: 2-3.

Yusuf S, Pitt B. A lifetime of prevention. The case of heart failure. Circulation. 2002; 106(24): 2997-8. 
Westphal MF. Recursos educativos e métodos de avaliação em promoção da saúde. São Paulo:Faculdade de Saúde Pública/USP; 1998.

Westphal MF. Promoção da Saúde e Prevenção de doenças. In: Campos GWS et al. Tratado de Saúde Coletiva. São Paulo: Hucitec; Rio de Janeiro: Fiocruz; 2006.

Wood DA, Kotseva K, Connolly $S$ et al. Nurse-coordinated multidisciplinary, family-based cardiovascular disease prevention programme (EUROACTION) for patients with coronary heart disease and asymptomatic individuals at high risk of cardiovascular disease: a paired, cluster-randomised controlled trial. Lancet. 2008;371(9629):1999-2012.

World Health Organization. The Ottawa charter for health promotion. Geneve:WHO;1986.

World Medical Association: Declaration of Helsinki. JAMA. 1997;277:925926. 